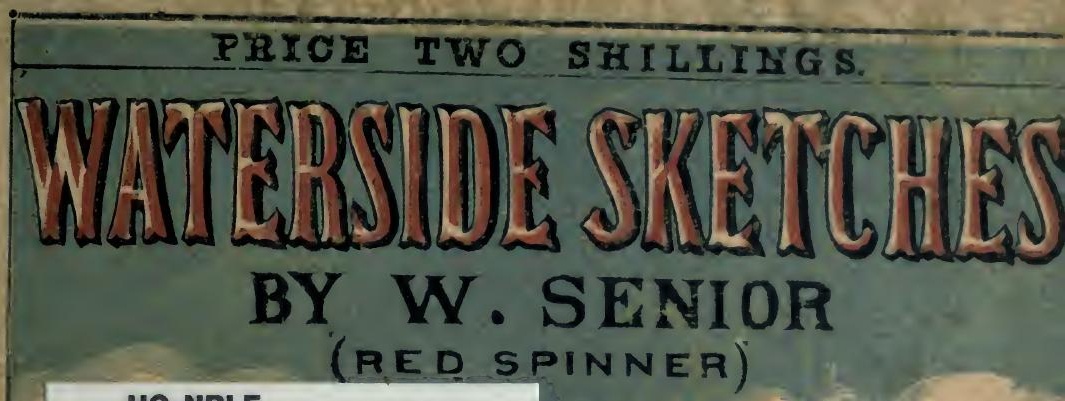

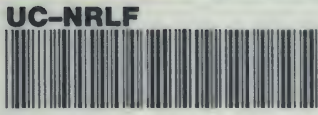

+B 271 ?2?

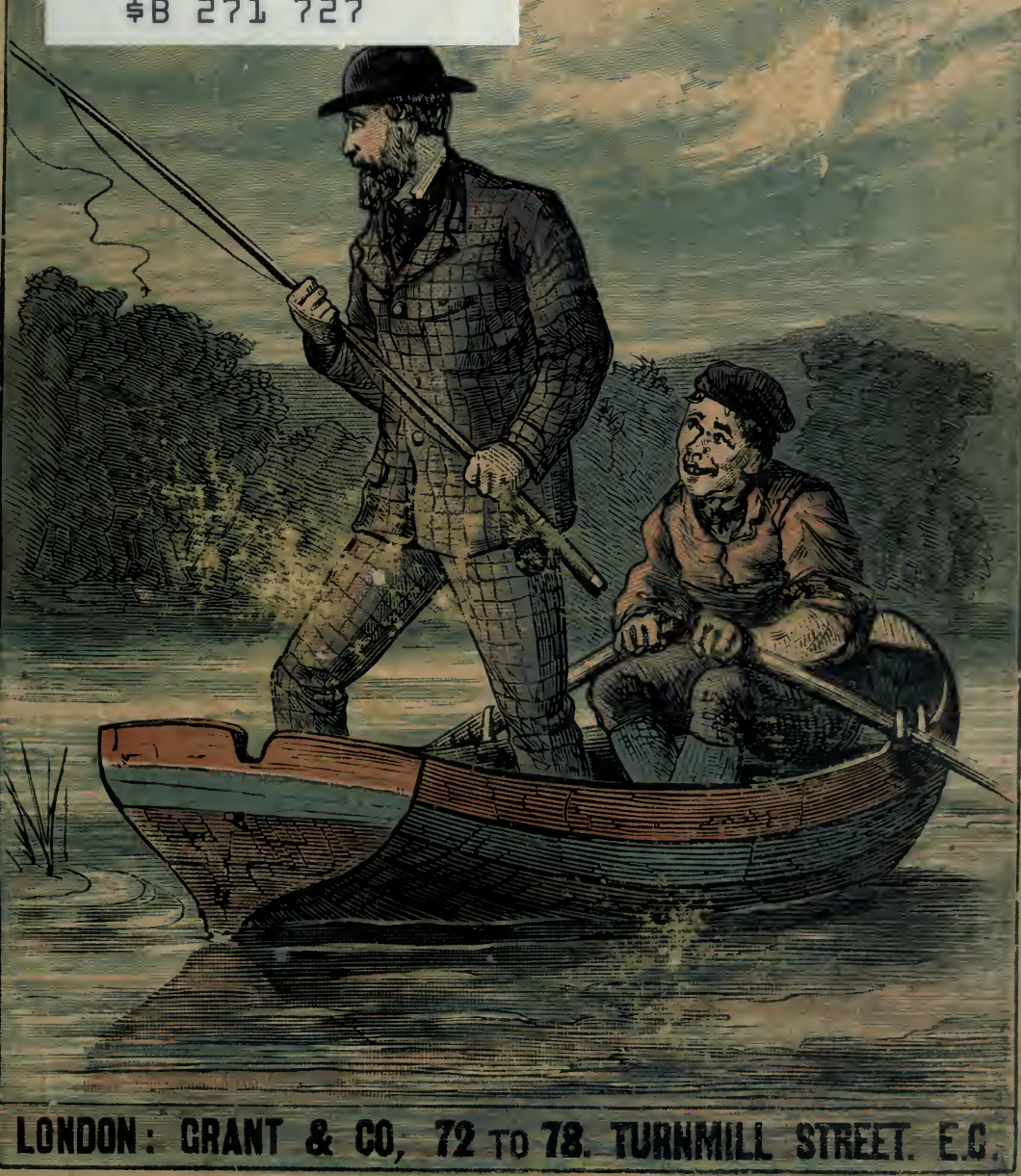




\section{B ERKELEY GENERAL LIBRARY UNIVERSITY OF CALIFORNIA}

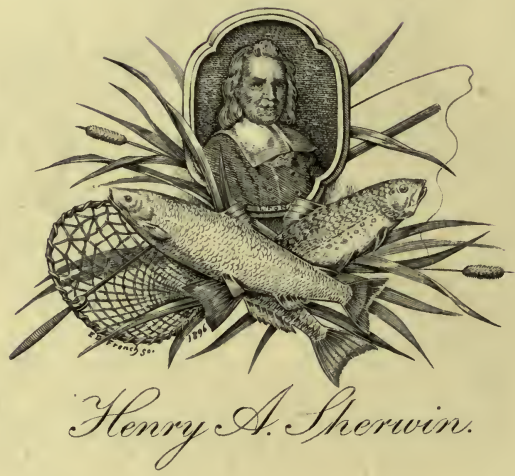

The SPORTINg Galler? AND BOOKSHOP, INC. No. 38, East 52 nd St., New Yor 


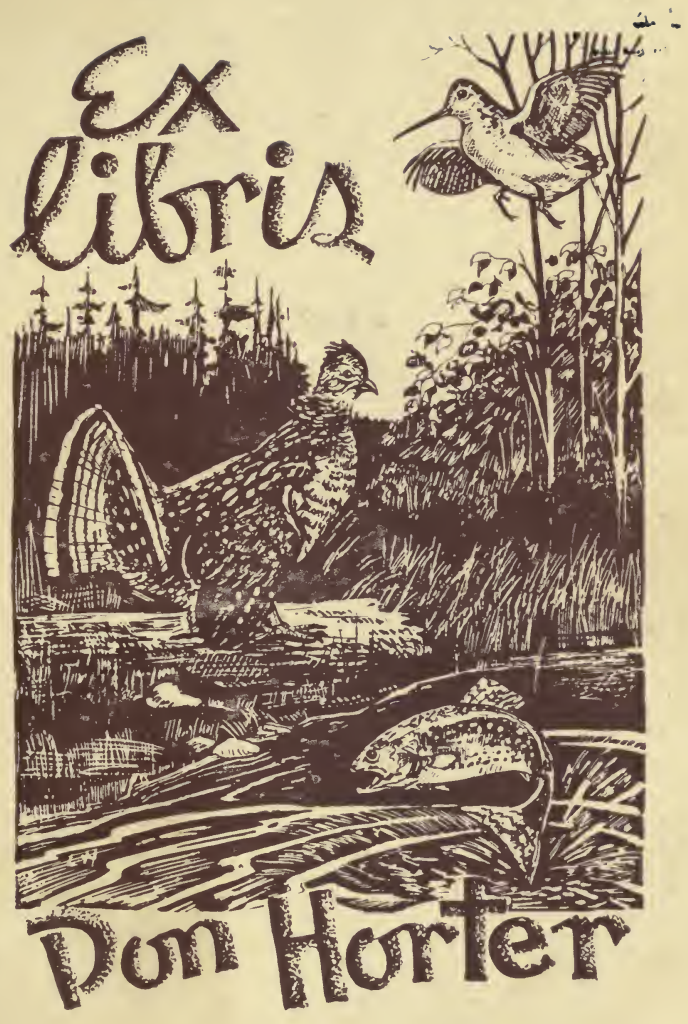


No PRIVATE LIBRARY,

. H. A. SHESWIH.

$\leftarrow$ 


\section{RE-ISSUE}

IN

\section{TWENTY-FOUR HALF-CROWN MONTHLY PARTS}

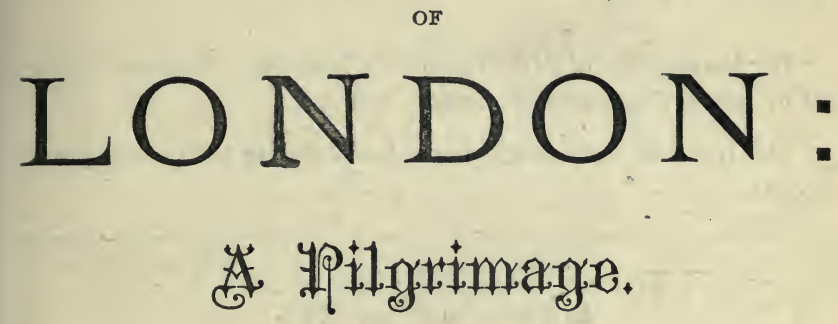

BY

\section{GUSTAVE DORí and BLANCHARD JERROLD.}

"The great city has for the first time found a great artist to go through its length and breadth, to picture its life in all its aspects, and there is every promise that the book of which this is the first part will prove worthy alike of its theme and its authors. M. Dore is seconded by an admirable engraver."-Times.

"A book which must take its place as a volume of art among our best works."-Standard.

"The work, as a whole, is beautiful in the extreme, and will constitute a volume of the greatest value and interest."-Globe.

"Mr. Punch is glad to welcome a new memorial of Augusta Trinobantum, especially as that city is being so rapidly 'improved,' especially in the parts most likely to attract the eye of $M$. Dore that it will soon be all as colourless as a Boulevard or Regent Street."-Punch.

London: GRANT \& CO., Turnmill Street, E.C. 
In 3 vols., post $8 \mathrm{vo}, 31 / 6$.

\section{O L Y M P I A.}

\section{By R. E. FRANCLLLON.}

"The leading idea of Mr. Francillon's book has one great meritthat of novelty."-Saturday Revierw.

"This is one of the best novels produced during the present year." -Globe.

In 2 vols., post 8 vo, $21 /$ -

\section{A \\ Rambling Story. \\ By Mrs. COWDEN CLARKE.}

In 2 vols., post $8 \mathrm{vo}$, cloth gilt, with portraits, $21 \%$

\section{WALKER'S}

"THE ORIGINAL."

Edited by BLANCHARD JERROLD.

London: GRANT \& CO., Turnmill Street, E.C. 
In I vol., demy 8 vo, 21 -

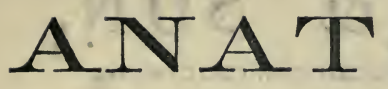

OR,

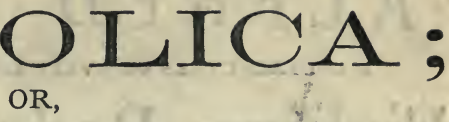

in the East.

Plates and Maps.

By Rev. E. J. DAVIS.

Now ready, in I vol., crown 8 vo, cloth gilt, 5 -

\section{PUBLIC MEN \\ OF}

Ipswich \& East Suffolk.

A Series of Personal Sketches.

\section{THE}

\section{GENTLEMAN'S}

\section{MAGAZINE.}

The Edinburgh Daily Review for Dec. 14, 1874, says:-"One of the phenomena of the literary year has been the resuscitation of the GENTLEMAN'S MAGAZINE, which, owning the influence of rare ability and energy in its new Editor, Mr. Richard Gowing, has, in a single twelvemonth, worked its way up from well nigh the lowest place amongst monthlies to one in the highest rank. It is gratifying to know that the public have not been slow to acknowledge the altered class of literary fare presented by that Magazine, and that the circulation, which has been steadily mounting throughout the year, is still increasing in quite an exhilarating manner." 


\section{ALFRED \& SON,}

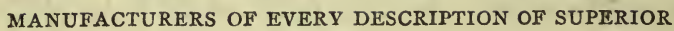

\section{Prsky}

ALFRED'S celebrated Light Cane Punt-Rods for the Thames.

Long Light Stiff Rods for Bank-Fishing.

Winches in Wood, Brass, Ebonite, Electro-plate, and Silver.

Tackle Cases furnished in great Variety.

Extra Fine Gut Lines and Hooks. Roach Tackle of every Description.

Artificial Fish, Flies, and Insectse "Otter's" Live Bait Snap for Pike.

54, MOORGATE STREET, E.C. ESTABIISHED 1819.

Price 2s., post free 25 stamps,

OTTER'S MODERN ANGLER.

Published by ALFRED \& SON, 54, Moorgate Street, E.C.

In crown $8 \mathrm{vo}$, cloth gilt, gilt top, $3 \mathrm{~s} .6 \mathrm{~d}$. $" \quad$ " in picture boards, $2 \mathrm{~s}$.

Waterside

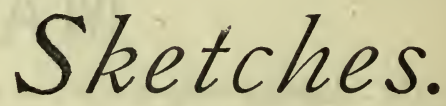

REPRINTED FROM THE "Gentleman's MAGAzine."

By W. SENIOR ("Red Spinner").

“ 'Waterside Sketches' are evidently written by a hand by no means inexperienced in the gentle craft of Izaak Walton." - Land and Water.

'London: GRANT \& CO., Turnmill Street, E.C. 
WATERSIDE SKETCHES. 
Digitized by the Internet Archive in 2007 with funding from Microsoft Corporation 


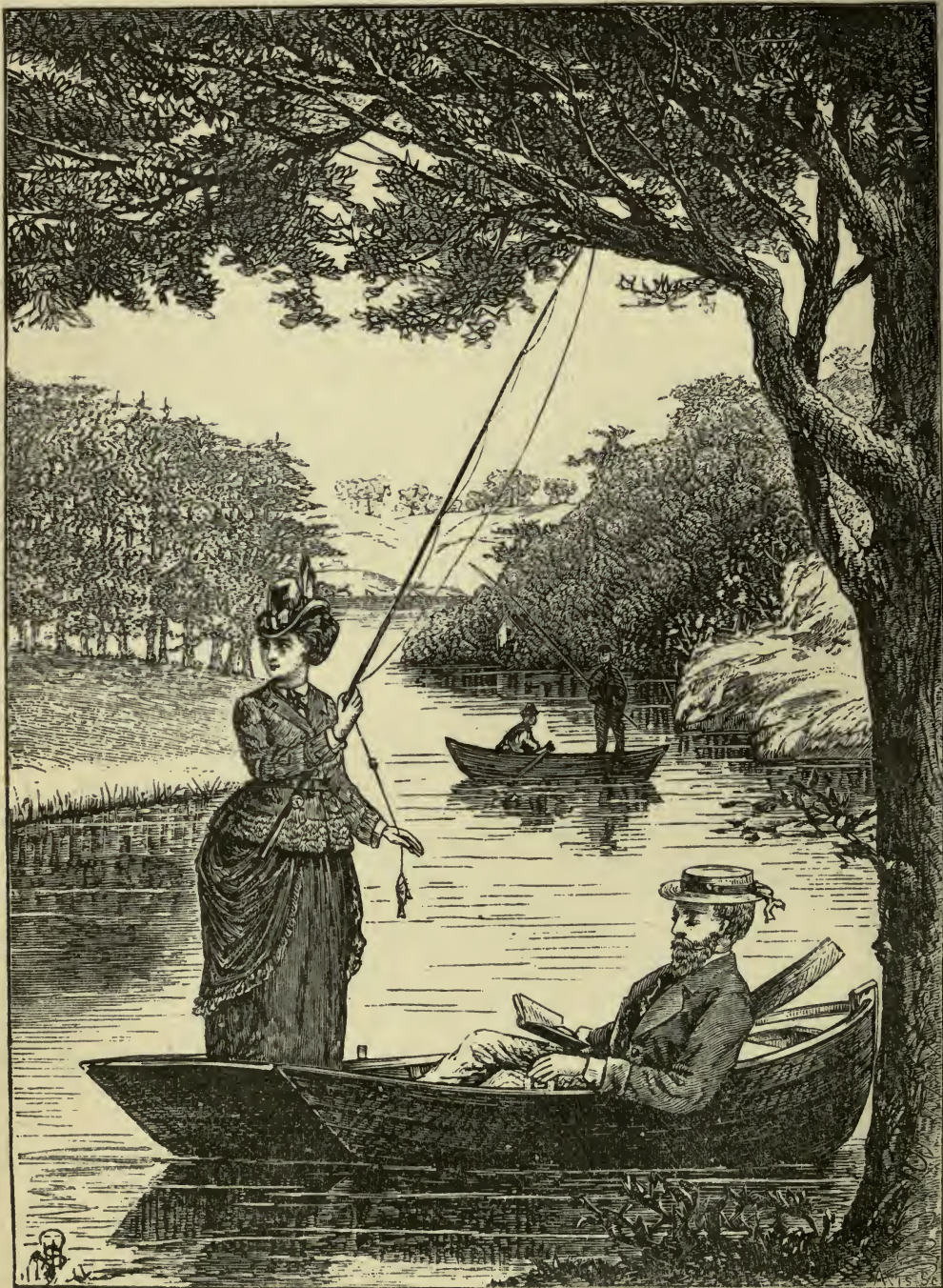

"HOOKED FOUL." (See page 2x6). 


\title{
WATERSide SKETCHES.
}

A Book for Wanderers and Anglers.

\author{
BY \\ W. SEniOR ("Red Spinner"), \\ Author of "Notable Shipwrecks."
}

"Sporting books, when they are not filled (as they need never be) with low slang and ugly sketches of ugly characters . . . furm an integral and significant, and in my eyes an honourable, part of the English literature of this day, and therefore all shallowness, vulgarity, stupidity, or bookmaking in that class must be as severely attacked as in novels and poems."

Charles Kingsley.

$$
\angle O N D O N \text { : }
$$

GRANT \& CO., 72 TO 78 , TURNMILL STREET, E.C.

$$
1875 \text {. }
$$

[ALL RIGHTS RESERVED.] 



\section{PREFACE.}

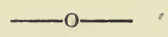

This book assumes to be nothing more than is implied in its title. The sketches do not even pretend to exhaust the topics of which they treat, much less to include all the subjects which might be reasonably looked for in a book for wanderers and anglers.

Some day, if the success of the present volume should warrant the undertaking, a second series of "Waterside Sketches" may make amends for present omissions.

Most of the chapters in this book originally appeared in the Gentleman's Magazine, but they are reprinted with numerous additions. The story introduced in Chapter X. appeared in Tom Hood's Comic Annual for 1874 .

W. S.

March 20, 1875 .

\section{$\overline{\mathrm{M}} 816512$}





\section{CONTENTS.}

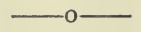

CHAPTER I.

PAGE

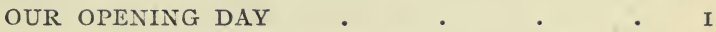

Practical Notes on April Fishing . I6

CHAPTER II.

THE MISYFLY • .

Practical Notes on May Fishing $\quad . \quad 33$

CHAPTER III.

THE thames . $\cdot$. . . 36

Practical Notes on Roach, Dace, and Gudgeon Fishing . . ' 58

CHAPTER IV.

A HOLIDAY IN DEVONSHIRE a . . 62

Practical Notes on Devonshire Fishing 84

CHAPTER V.

IN THE MIDLANDS $\quad \cdot \quad$. $\quad$. $\quad$. 87

Practical Notes on Bream, Barbel, and

Chub Fishing . . . . III

CHAPTER VI.

WHARFEDALE • • • . . 115

Practical Notes on Grayling Rivers $\quad 133$ 
viii CONTENTS.

CHAPTER VII. PAGE THE ANGLER IN IRELAND Practical Notes.

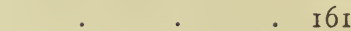

CHAPTER VIII.

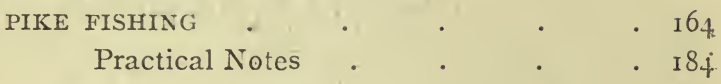

CHAPTER IX.

FRESH AND SALT . . . . I88.

Practical Notes on the Norfolk Broads . 206

CHAPTER X.

HOOKED FOUL . . . . . 210

CHAPTER XI.

UNLUCKY DAYS IN WALES • . $\quad 227$

Practical Notes on Welsh Wraters . 240

CHAPTER XII.

OUR CLOSING DAY • • . $\quad$ • 242 


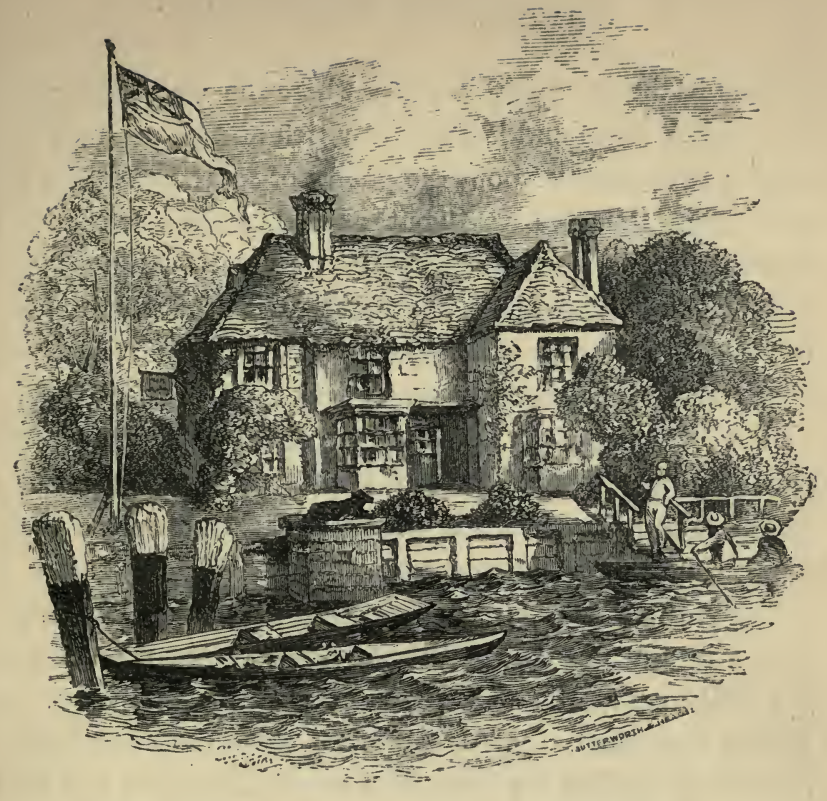

\section{WATERSide Sketches.}

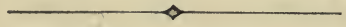

\section{CHAPTER I.}

\section{OUR OPENING DAY.}

"Away to the streamlet, away, away! The Sun is up in his realms of light. But it is not alone from his captured prey That the fisherman wins his keen delight. Ah no! 'tis the breath of the infant day, 'Tis the air so fresh and the sky so bright In these is the fisherman's best delight."

That is all very true and pretty, but I am still inclined to agree with the late Charles Kingsley-one of the best 
anglers in the moorland country where he lived, died, and lies buried, loved and lamented by rich and poor-that it is best to say nothing about the poetry of sport. "I can see nothing in it," he says, "but animal excitement, and a certain quantity, I suppose, of that animal cunning which the Red Indian possesses in common with the wolf and the cat, and any other beast of prey. As a fact, the majority of sportsmen are of the most unpoetical type of manhood. . - . For most of them it is sport which at once keeps alive and satisfies what you would call their æsthetic faculties, and so-smile if you will-helps to make them purer, simpler, more genial men."

Truly, the worthy Hampshire rector delivered these sentiments in the red deer country, and rather in reference to the huntsman and marksman than the less active angler, but never was truer sentence spoken than that concluding remark of his that we English owe too much to our field sports to talk nonsense about them.

Yet if any sportsman has the right to foster sentimentality it is the fisherman. We anglers of this and every other period have been charged with being coxcombs, fools, and what not; and such we may or may not be. I don't mind crying "Peccavi," however, to one accusation made times out of number against us : we are no doubt a gossiping race, and all we can plead in mitigation of sentence is that our garrulity is at least harmless; which is more than some gossipers dare aver.

Come with me for an hour or so to a haunt sacred to fishermen's gossip, and judge for yourself. Following the example of the immortal Izaak, I will trouble you, as we walk, with some preliminary prosing. You will find, then, 
that angling is not the thing it was when Piscator overtook Venator and Auceps on the road to Ware; Auceps on his way to look at a hawk at Theobald's, Venator to join in an otter hunt at Amwell, and Piscator, the avowed brother of the angle, to pursue his gentle art, sitting and singing under the high honeysuckle hedge, while the showers fell gently upon the teeming earth, and gave a sweeter smell to the lovely flowers that adorned the verdant meadow. Hawking no longer takes place at Theobald's ; there is no necessity for rising before the sun to meet the otter pack on Amwell Hill; and the times are gone when the Hertfordshire milkwoman would offer the passing angler a syllabub of new verjuice, a draught of the red-cow's milk, and her honest Maudlin's sweetly sung song.

The modern Waltonian, nevertheless, has, on the whole, little cause to grumble at the change which has come about; there still remain pleasant haunts and moderate chances of sport, and if he be unable to kill roach at London Bridge and fill his basket within an hour's walk of town, increased facilities by rail and steamboat bring opportunities within his reach never before enjoyed. In the great law of compensation upon which the world is said to move the modern Waltonian shares. The mines, manufactories, and mills do their best to pollute the few fish-breeding rivers that are left to us ; but there is a keen spirit of preservation abroad, and all over the country influential associations are continually imitating the noble example set them by the Thames Angling Preservation Society.

Taking us the country through we are a very numierous body; year by year additional recruits avow their conversion to the "Contemplative Man's Recreation." Some of 
these fine days, when English anglers hold a grand Waltonian fete at the Crystal Palace, or, being nearer the scene of Walton's perambulations, in Alexandra Park, the world, I venture to say, will be not a little astonished at the numbers who will take part in the demonstration. Angling fraternities with various names and mottoes flourish in many a town; aye, in the most dismal and poorest quarters of London's City. For angling literature there is a healthy and perpetual demand.

The town fishing club somehow is treated with a derision it hardly deserves by the fortunate gentleman who is able to kill salmon in Norway or Ireland, deer in Scotland, and trout in Wales; its members are regarded with contempt by the lordly sportsman who would faint at the sight of a lobworm, and be aghast at the notion of ground-bait. This is neither fair nor considerate. The city-pent Cockney, poor fellow, must do what he can, and the shabby apprentice who walks from Shoreditch to Tottenham, bait-can in hand, every Sunday morning, and is content with such results as his humble rod and line may bring, may be at heart-why not?-as true a sportsman as the happy individual who goes forth with a couple of keepers at his heels, and the costliest tackle and finest streams at his command.

But a truce to prosing, at least for the present, for here is the Waltonian's home. You may see that we are a very united family, and not ashamed to avow ourselves followers of quaint, pure-hearted Izaak Walton. We aim, in our several ways, to emulate his spirit, which was eminently unselfish. We are unknown to the world, but we know each other, and hold as a primary article of faith that the man who possesses a good fishing-rod, a stout walking-stick, and the 
opportunities and means of using both in moderation, ought to be happy and healthy. This brotherhood of men who love the gentle art with unswerving fidelity includes persons through whose estates well-stocked salmon-rivers sweep, but some of these days you shall see them enjoying with the keenest relish an afternoon's roach or gudgeon fishing by the banks of a prosaic stream. We earn our right to recreation by work of divers kinds-on Exchanges, in Government offices, in establishments where printingpresses groan and struggle, in Westminster Hall, in chambers; we buy and sell, we toil by brain and hand, we are rich and poor, we are old and young, but we are not ashamed a second time to avow ourselves followers of quaint, pure-hearted Izaak Walton, whose nature was eminently unselfish.

By listening quietly awhile you will discover how true it is that we are a gossiping race; but note that our talk is all of one warp and woof. This is the hour when the smoking rooms of clubs where politicians and the great ones of the earth do congregate are handling freely public and private scandals, questions of national pith and moment, controversies weighty and bitter. Here we are in the town, but not of it. We are bodily present, but in spirit far away. Possessing in common a devotion to angling, there are all kinds of branch fondnesses by which certain men are known, each warranting, however, Washington Irving's observation, "There is certainly something in angling that tends to produce a gentleness of spirit and a pure serenity of mind."

There is not a man present to whose love of angling there is not grafted some other pleasant pursuit or liking. 
Here is a fern lover who has actually been known to miss the striking of a fish on suddenly espying a goodly specimen of his favourite plant. To another the pocket sketch-book is the most necessary item of his fishingkit; his friend is full of learning as to forest trees and wild flowers; ornithology is a common acquirement with the majority. I could point you to one who captures: more butterflies than fish; to a second whose weakness lies in tadpoles, newts, and snakes. Out of the fullness. of the heart the mouths speak, producing a medley of conversation truly, and an exchange of miscellaneous experiences, but no ill-humour, no treason, no railing.

It is the last night in March, and we muster in force amongst our old acquaintances, the trophies encased around the walls. How we fight our piscatorial battles over again! That monster pike glares as if he were cognisant of the story re-told of his folly and fall-how, greedily grabbing at the gudgeon that was intended for a passing perch, he, twenty-eight pounder though he was, was struck, played, exhausted, and landed with a single hook, which you may observe coiled up in the corner of the museum, to his everlasting disgrace.

The eyes of our old friend whose prowess amongst the salmon and white trout is a proverb at Glendalough and Ballina, and has been known there these twenty years, will glisten again as he describes the history of the three large trout overhead, caught in three casts within a space of thirty minutes. And soon a patriarch takes up the parable; he is as enthusiastic at three score and ten as he was when, a truant, he slew small perch near Sadler's Wells Theatre, and he will set. 
us in a roar by his comic recital of a day's bream fishing on one of the Norfolk Broads, and the cowardly behaviour of the flat bellows-shaped brute in the compartment next but one to the sixty-three-ounce perch.

And so we pass the time, silently overlooked by carefully preserved tench, carp, barbel, dace, roach, rudd, and pike, which strangers come from afar to admire, and which recall many a pleasant memory to be fondly lingered over and cherished; and smiled upon benignantly by the ancient picture of a wholesome looking old man, with long white hair, smooth face, steeple crowned hat, and broad white collar-the man who is father of us all.

To-morrow a small party are bound on an expedition to the waterside according to annual custom. We begin our campaign on the ist of April. News of fish feeding and moving has arrived by express to gladden our hearts. Some of us have already opened our fly-books by the early streams elsewhere, and are hoping to do gallant deeds with a particularly neat March brown that is never out of season. Others have been busy during the day removing rods and tackle from their winter resting-places, and in lovingly preparing them for active service.

Do you smile at the high character given to so simple an occupation? Then you know not how fertile are the sources whence spring the angler's joys. When the north winds blow, and the east winds bite, and the yellow floods overflow the spongy banks, and the fisher is a prisoner at home, he forgets, in overhauling his stock, both his ill-luck and the unfriendly elements. He sits at the blurred window with his scissors, waxed thread, varnish, feathers, fur, and wool spread out before him; he tests his lines and casts, 
oils his winches, and resolves himself into a committee of inquiry respecting the joints and tops of his rods, which he regards as companions to be communed with, praised for merits, and remonstrated with for faults. Rest -satisfied, therefore, that our friends who to-day have brought their implements into the light for the first itime since autumn have set about their task in the spirit of no common or vulgar ransackers.

To-morrow arrives: All Fools' Day, as we pleasantly remind each other. Happily March had come in like a lion, or rather like a bellowing bull, and had, true to tradition, departed like a lamb, leaving immediately behind it the loveliest of spring mornings. Three hours before we had the smoke and noise of London; now we are surrounded by sights and sounds that make us glad at the mere thought of life. Our veteran, whose rod the keeper is carrying, drinks in the balmy air in great gulps, and if the grass were a trifle less wet, would frisk it merrily amongst the lambkins in the mead. The birds, still in their honeymoon, make unceasing melody in the hedges, and you can hear a grand responsive chorus away in the dark wood, from whose trees the grip of winter has just been relaxed. The impudent water rats evidently hold us in supreme contempt, scarcely deeming it necessary to plunge from their holes and perform that light-hearted somersault which so often startles the unsuspecting rambler. There is life and the promise of life everywhere, and we revel in it, and feel kindly towards all mankind.

Rods are put together, and it will go hard with not a few innocent fish if the eager looks of certain of our band carry out all they express. April clouds are scudding 
softly over an April sky, and there is a friendly breeze from the west ready to aid the angler. The river runs smooth and deep here, but a little space ahead it tumbles into a noisy weirpool, boiling and fretting, and ejecting from its troubled depths an occasional weed or stick. At the rear of the osier bed a placid backwater winds, and here one, two, three, and four of our brotherhood are settling down to a few hours' special correspondence with the tench, just now in their prime, and, with this wind and water, almost certain to be off their guard.

We will stroll round that way by-and-by. But en passant I would advise you never to hurry by this corner with your eyes shut, for as the April days multiply there will appear in all their vernal glory a host of marsh flowers and plants. The village children, romping and hallooing in the distance, are bound for the copse to search out wood anemones, the woodruff, the wild hyacinth, lords and ladies, strawberry blossoms, primroses, violets, crane-bills, and (as they will call them) daffydowndillies; but our ruddy-faced little friends are too early in the season, and will meet with but a portion of the treasures they seek.

Now let us pause at the weir, and watch our gay young comrade do his will with the phantom minnow. If he handle his papers at the Circumlocution Office as deftly as his spinning-rod he ought speedily to reach a distinguished position in the Civil Service. But he does not find a fish instanter, nor will he succeed until the cast places his bait in command of the furthest eddy and scour. This our gay young comrade in due time neatly accomplishes, and his reward is a vicious snap, a taut line, and a thrilling rod.

It is a heavy trout, as you may see by his pull; a lively 
trout, from the speed with which he darts round and across the pool; an artful trout, by his rush for the shallows; a beautiful trout, self-proclaimed in a succession of leaps into the air, during which the sun lights up his ruby spots and burnished vesture; a princely trout, as you must admit, for the keeper, who knows that the first fish of the season is always an extra coin in his pocket, stands by with the weighing machine, and announces him a few ounces short of five pounds. He is a goodly fish, yet personally I hold him in light respect, being convinced that nothing would ever induce him to rise at a fly. We have been long familiar with these lusty trout, with their haunts, their vices, their virtues, their dispositions. Sometimes they take a clumsy dead gorge bait, sometimes a live roach, or gudgeon, sometimes minnow or worm, but never a fly, artificial or real.

This straight level run is a roach swim, famous amongst us; by these fast-springing flags three years ago a young gentleman who had never seen the water before, and was apparently a novice in the craft, in one afternoon caught a great weight of roach, four individuals of which turned the scale at eight pounds, several of which were over a pound, and none of which were less than six ounces. Presently we reach another weir, and soon a third, and in each our gay young friend will before night seek a companion for the beauty we assisted, a few minutes since, to smother in newly cut rushes.

We are now, let me whisper, making our way to a tributary streamlet, upon whose rippling surface the flies dangling over my shoulder will receive their first baptism. The brotherhood have various tastes, and agree to differ with perfect good humour. Our friends at the backwater are 
not unfriendly to me, personally, but they pity my weakness for fly-fishing. I dote on our victorious young comrade of the weir, but nothing could induce me to toil throughout the live-long day spinning for a brace of trout, if the chance remained for me of a dozen troutlets fairly killed with the artificial fly. Each man to his liking, and good luck to. us all: that is our motto.

When we turn out of the next meadow, in whose trenches. a few weeks hence will blow-

$$
\text { "The faint sweet cuckoo flowers," }
$$

and where-

"The wild marsh marigold shines like fire in swamps and hollows grey," look straight at the rustic bridge spanning the ford, and you will see a couple of fellows lounging upon the hand rail. They are poaching rascals on the watch for the prowling trout that push up from the wider water below to chase the small fry on the shallows, and when the sun: comes that way it would be worth while spiking your rod into the coltsfoot-covered bank, lighting another cigar, creeping stealthily behind the willow bushes, and watching the actions and habits of the fish. Such time is never thrown away, and you. will soon discover that the fish are not unworthy of your inquiring study. As to the hulking. scoundrels beyond, after nightfall there will be a splash and a struggle, and an hour later the poachers will probably be offering a couple of handsome trout for sale at some village pothouse.

Across a bit of young wheat, down a lane where we could find a posy of white violets if we had the leisure to pluck them out of their modest retirement, and we reach the narrow winding streamlet where, fortune favouring, 
us, I may ply the fly to some purpose. But what with poaching, the increase of anglers, and vile pollution everywhere, trout, alas! except in very remote parts, are becoming scarcer and scarcer every year, and it requires the utmost skill to bring the fish to basket. Unfortunately this streamlet is poorly stocked, and there is not a solitary tree or bush to cover its banks. On the other hand, the water is neither too high nor too low-an inch makes a vast difference here-and the factory above has been good enough not to pour out its discolouring refuse to-day. But I must creep to the water and move stealthily.

As it is a small stream, of course, on that strange law of contraries which guides the angler in these matters, full sized flies must be employed-the invaluable March brown as stretcher, the cowdung (considering the warm wind) for dropper number two, and the blue dun number three. You cannot detect the ghost of a rise anywhere, and cast after cast ends in the same monotonous disappointment. Try every art within your knowledge, still no success. Put on the stonefly for the blue dun; the result is the same, although the flies fall light as snowflakes on the ripple.

At last I have carefully covered every yard of the short length of streamlet at our disposal, fishing according to orthodox rules, and-pardon the egotism-fishing it thoroughly. I am too much accustomed to the certain uncertainties of angling to be disheartened, although it must be confessed I am anxious not to return to the brotherhood empty-handed. Now let me be unorthodox. One of the lessons I was taught in the early days was not to use a red spinner till May. The red palmer is permissible 
in both February and March, and often very killing; and in April your book is not complete without both brown and grey spinner; but the red spinner by very many worthy folks is not regarded as appropriate till May. In that case I mean to anticipate the season by a month, and substitute my favourite red spinner for the stonefly, which has been unsuccessful. The cowdung-fly must remain, for that insect is unmistakably abroad, circling in the wind with its usual activity. The March brown has been so firm a friend that I seldom discard it, early or late, and it shall not be discarded now. Still something must be done.

One method is left untried. I plump down upon my bended knees, well away from the brink, winch up the line to a few yards, and cast close under the opposite bank, upon it if possible, and rather below than above. This, too, some dogmatists would condemn as unorthodox: but is not the proof of the pudding in the eating? The flies, sinking somewhat, are borne with the stream, and I am keeping my eye closely upon the red spinner, which the wind dances naturally upon the surface, and which it is my intention to work slowly, dibbing fashion, across to the hither bank. In a few minutes I feel a trout, and I want no information as to his quality; he has shot athwart stream with a deep strong pull, and bent my light rod like a whip. He was lying almost close to the bank on my side of the water, and never broke the surface in seizing the fly: he waited until the red spinner dipped, and then in a business-like way closed upon him once for all.

Twice afterwards my attendant has the pleasure of using 
the landing net, but only with the normal half-pounders of the stream. Yet we are quite content and happy, and stroll lazily back to the brotherhood with clear consciences.

The gay young comrade it seems at mid-day has found a fitting mate for his captive from the weir, and is, as we pass, engaged with his friends and the keeper in a vain endeavour to rescue his spinning flight from a submerged tree trunk. We comfort him with the assurance that the chances are twenty to one in favour of the willow-wood holding its own. Our brethren at the backwater, comfortable on their campstools, with many an empty bottle upon the trodden grass, and the débris of a heavy luncheon at their feet, have had the premier sport of the daymeasuring sport by results. The tench have behaved themselves in a freehearted and appreciative manner, and, save that they manifested an unaccountable dislike to one gentleman, showed no preference for particular anglers.

Four rods have been constantly at work, and three have been constantly taking fish. The fourth is in the hands of the undoubtedly best angler of the party, and he uses the finest gut and hooks, but, to his chagrin and surprise, while his friends have caught fish whether careful or careless, he has not perceived so much as an accidental nibble. Finding him accordingly in a despondent frame of mind, we cheer him with such cheap comfort as we can find at a moment's notice. Even as we speak his delicate float trembles, and then rises slowly and mysteriously until it lies flat upon the sluggish water. Every angler knows the meaning of that welcome token. There is much jubilation over such a beginning, and we feel it right in duty bound to drink each other's health in a flask of brown sherry, which 
one of the brotherhood-a City man of course-produces with a flourish.

What follows aptly illustrates the unexplainable fancies of the fish world. For an hour the previously unsuccessful fisherman hauls out as fast as he can bait his hook, and his three friends, who had been pitying him for hours, are now recipients of our compassionate regrets. There is no rhyme or reason for this sudden whim of the tench, and at the termination of the hour, the biting ceases as suddenly as it began, and not another fish is brought to land.

The tench had taken well-scoured marsh worms, absolutely refusing to touch either striped brandlings, tempting lobs, or able-bodied gentles, and it was noticed as a curious circumstance that while at one spot the bites were sharp and vigorous, the float disappearing without much hesitation, a few yards off the fish dawdled over the bait, as tench frequently do, leaving the angler in doubt whether the movement of the float was not a mere accident. As the bottom was muddy rather than gravelly, the anglers had naturally fished a couple of inches from it, and, all told, were, on quitting the field, able to show a total of over twenty pounds, which, for so capricious a fish as the tench, may be considered great sport.

Our Opening Day we deem on the whole all that could be wished. We can say with the philosopher "Our riches consist in the fewness of our wants." If we can boast of no sensational creels, we are all satisfied and at peace with each other. Hungry as hunters, we gather in the eventide round the table of our pleasant room, beneath whose balcony a bye-stream hurries, mad with the impetus received from a weir at the bottom of the garden, and foaming with . 
anger as it shoots under the roadway. Incidents of the day, trifling in themselves perhaps, and bits of observation and experience, not startling or profound it may be, are exchanged, while the clink of the knife and fork beats time to the soothing plash and flow outside the window.

And so our Opening Day, like all other days, runs to its close, and to-morrow we shall be at our posts in the busy spheres of the big city, better surely rather than worse for those pleasant hours by the waterside?

\section{Practical Notes on April Fishing.}

Trout are in prime season in April, which in many rivers is the angler's most remunerative month. It is also not the least pleasant, since the world of beauty towards. its close begins to open on every hand. In spite of its proverbial showers, trout streams are on an average in excellent order in April, being neither too much coloured nor too low. Each day of warm weather brings out new insects, which the trout, after their long recess, are fully able and willing to appreciate. In the matter of flies, 'though it is well to understand the art of dressing them oneself, fly manufacture has been brought to such a pitch of perfection that it is cheaper and more convenient, as a rule, to trust to the tackle shops. The ordinary trout. in April has a good deal of Cassius-like leanness about it, and is very different in colour and firmness of flesh to the fellow who has had his gorge of the Mayfly.

The tench may not be the physician the old fishing. masters believed him to be, nor an object of superstitious veneration to the pike, as many living anglers think, but: 
he is a much better subject for the table than is supposed. A fat tench weighing about a pound, coming as it does in a month when our fresh water fishes available for the table are very limited in number, is excellent eating, and it is amazing that it is not better known to the cook. The fish spawns about, but seldom before, Midsummer, and is, if river bred, most delicate eating in March and April. It thrives nowhere so well as in the ornamental lakes of private grounds; on a hot July day fish of from two to seven or eight pounds may often be seen floating nearl the surface, or moving uneasily amongst the weeds under which they spawn. The angler for tench requires a double stock of patience; in the early morning, before the hoar frost has vanished from the spring grass, rapid sport may be sometimes had with fine tackle. Later in the summer in warm rains and on cloudy days a good dish may be reasonably expected, and it may as a rule be held that large worms take large fish. I have taken tench with plain paste while fishing for roach, but this was doubtless an accidental occurrence. A well-scoured marsh worm is in every way the best bait for tench; wasp-grub is also a taking lure. The cookery books prescribe the stew-pan for this fish; to get out of it all that it is worth there is nothing like filleting; and the same cleanly method of cooking holds good with almost every kind of fish. The tench is often spoiled by fancy sauces of wine and other ingredients. Tench and eel skinned and boned, in a savoury pie, and eaten cold, make a most toothsome combination for the breakfast table. Perhaps the quickest and easiest way of cooking a tench is to split and fry it thoroughly brown. 


\section{CHAPTER II.}

\section{THE MAYFLY.}

"Fly disporting in the shade, Wert thou for the angler made?

To grace his hook-is this thy fate?

And be some greedy fish's bait?

Fly aloft on gladsome wing!

See one comes with eager spring,

He'll dip thee far beneath the wave :

And doom thee to a watery grave."

MAY has nearly run its course. We have an ancient promise that the seasons shall never fail, and though sometimes our variable climate makes it difficult to draw a hardand-fast line between summer and winter, in the long run you may be sure seed-time and harvest come round in very much the same fashion as they appeared to our forefathers. I pack my portmanteau as I make these sage reflections, and am grateful that the spring has been one of the timehonoured sort. March winds prevailed at the proper time, the April showers fell soft, and the May flowers bloomed without delay. And there has arrived a letter announcing the advent of the green drake.

Mayfly fishing is not, to my mind, altogether a satisfactory style of angling, yet I grieve me much if the Mayfly season pass without taking advantage of it. The fish are so terribly on the "rampage" at this time that it seems like catching them at a mean disadvantage. The silly trout 
evidently take leave of their senses for a fortnight or so, at the close of May or beginning of June, and, of all ranks and sizes, lay themselves out for unlimited gorge. The angler, however, places himself more on an equality with his game if he forswears the live fly. If I ' were asked for my advice I should say :-Seldom use any but the artificial Mayfly, if you would live with a clear conscience; then you will have the additional gratification of knowing that the special difficulty experienced in producing a really good imitation is a slight set-off against the greediness of the trout at the Mayfly period.

Cotton, who even in these times of increasing piscatorial wisdom and research very well holds his own as an authority on fly-fishing, speaks of Mayflies as the "matadores for trout and grayling," and he adds that they kill more fish than all the rest, past and to come, in the whole year besides. It should be remembered that Cotton was then writing of the picturesque Dove, not so superbly stocked with trout and grayling now as it was in his days, but still as limpid and romantic as when Piscator welcomed his disciple to the Vale of Ashbourn with-"What ho! bring us a flagon of your best ale"- the good Derbyshire ale which Viator had the sense to prefer, scouting the idea that a man should come from London to drink wine at the Peak.

As a rile-and there are not many exceptions to it-the flies that suit one river fail on another; but the Mayfly is the touch of nature which makes most rivers kin. With some allowance for difference of size, your Mayfly will answer on any stream, or on lake and stream, during the few days in which the green and grey drakes make the most of their chequered existence. What Cotton wrote of the 
Dove will therefore apply to streams that in no other respect could be compared with it.

It is not the Dove to which I am bound. My stream is not half so well known either to anglers or to the nonangling world. It has a name nevertheless, and appears accurately marked upon the Ordnance Map. Let us for convenience sake call it the Brawl. In most instances you will not err greatly in disliking the fisherman who refuses to tell his brother where to find sport. It is true, necessity has no law, and the necessity is often laid upon one, sadly against his will, of withholding information which might be of service to a brother angler. $\mathrm{He}$ may be the best and most generous hearted fellow in the world, but he may lack that essential backbone of wisdom, discretion.

A few years ago a north country nobleman generously gave ordinarily decent persons leave to fish a well-stocked pike water-a privilege which many used and enjoyed. One day the pike were "on the move," as the saying goes, and two tradesmen who had secured the required permission were able by a liberal employment of live bait to row ashore at night with nearly two hundredweight of slain fish. Worse than that, a local paper made the achievement the subject of high eulogium, and congratulated "our worthy townsmen" on their prowess. What was the result? The noble owner himself assured me he received two hundred and forty applications in three weeks, and that he would never more allow other than personal friends to cast line into the water. And he has kept his word.

Therefore the stream now in question shall be named the Brawl, and I give fair warning that the rest of my nomen$c^{\text {lature in this chapter is also drawn from the source }}$ 
whence a member of Parliament was accused of drawing his facts-namely, the imagination. There is no objection to your knowing that the spot is not far from the cradle of the queenly Thames; so near, in fact, that you may almost hear the first babblings of the infant river. Green hills stand in rich undulations of pasture high above the surrounding country, giving to the sheep grazing on the luscious downs a name that is distinctive and far known. The Brawl does not rise, as many streams do, through the silversanded floor of a bubbling spring sequestered in the dell, but it spurts sharply out of a hillside, and commences its course, as it were, with a grand flourish of trumpets and waving of flags. Tennyson might have had the Brawl (but of course had not) in his mind's eye when he wrote "The Brook." The forget-me-nots are there, and the cresses, and the shallows, and the windings, and all the melody which tinkles in the Poet-Laureate's exquisite song.

When a man travels the best part of a hundred miles for one day's amusement he is generally prepared to crowd as much work into that day as human possibilities allow. How fresh the country looks in its May garment of many colours, and how majestically the sun rolls behind the great hills towards which I am rattling in the ravenous express! As if the landscape is not already gay enough with its foliage and flowers, the sun clasps it in a parting embrace, and at the touch it becomes radiant and rosy and soft.

The village is hushed in repose by the time I am left, the only passenger, on the rude platform, and the ancient churchyard is wrapped in shadow that becomes weird and black in the avenue of cypress and yew. The bats wheel 
hither and thither over the housetops, and beetles drone as they fly. The last roysterer-he is sober as a judge, and it is but ten o'clock-is leaving the Hare and Hounds at the moment I lift the latch to enter. The landlord eyes my. rod and basket, and glances sidelong at me during supper time. Seemingly his thoughts are sworn in as a common jury trying my case, and the verdict appears to be in my favour. I begin bargaining with him for a waggonnette to-morrow, and he takes an interest in my doings, hopes I shall have a fine day, good sport, and plenty of it.

Lastly, le informs me that he himself is a rodster, and proprietor of a willow bed through which runs about two hundred yards of the Brawl, and that if I would like to try my casts upon it in the morning before starting up the country I am welcome so to do. He does not give this privilege to every one, he says, and could not if he would, since he has let the right of fishing to an old gentleman living on the spot, reserving to himself the power which he now offers to exercise in my favour. The programme for to-morrow includes a small lake across country, and then a drive of six miles into the uplands to where the newly-born Brawl turns its first mill-wheel. Still, no reasonable offer or likely chance should be refused, and the landlord's kindness is accepted with thanks.

Before the lark is fairly astir next morning I am being brushed by the dew-charged branches of the trees in the landlord's willow bed. The tenant, the old gentleman previously spoken of, is known to the world as "the General." He was a sergeant of dragoons in his younger days, and now in the evening of life lives in a honeysuckled cottage overlooking the bit of animated stream in 
which he finds so much amusement. Perhaps if I had known this earlier I should not now be trespassing upon his preserves. Quite Arcadian the place must be; his rods, used beyond doubt last evening, he has left by the river, and they lie without attempt at concealment on the wet grass.

It is a very likely locality for a good trout, and circumscribed as the bounds are, there are deeps, eddies, and scours in excellent condition. More by way of wetting the line than anything else, I cast up towards a sweeping shallow, around whose edge the pure silver-streaked water swirls sharply, and at the second throw rise, and, I am free to confess, to my surprise hook a fish. The accident being attributed by the landlord to masterly skill, he stands by admiringly and excitedly with the net. The trout, however, is in no hurry, and runs straight into a forest of weeds, from which it seems impossible to extricate him without loss of tackle and time. The landlord rushing to the cottage for a pole brings with him "the General," half dressed, and in a pitiable state of alarm and anxiety. Almost with tears and in broken accents he says :

"I've been working three days for that fish, sir, early and late; he rose once yesterday, and twice the day before."

Poor old General! I feel sorry indeed, but sorrow cannot undo the unconscious wrong I have perpetrated! After tremendous exertions with a pole and hay-rake we loosen the tangled weeds, and the trout comes in on his side, not the patriarch we had supposed, but a burly little fellow nearly as large as a Yarmouth bloater. Then "the General" rejoices, and I too rejoice on hearing that "that 
fish" which has been tantalising him all the year is still left to tantalise him again.

"The General" begs me to remain for five minutes, and disappears. In his absence I notice that he has been using the live drake, the dead fly, a humble bee, and a worm. Those baits remain transfixed as he left them last evening, and admirably do they conceal the hooks. Now he reappears with a ruddy-faced girl, his daughter, who having, by my gracious leave, studied the artificial fly which has proved so effectual, thanks me with a smile which breaks upon her countenance like the rise of a tranquil trout, and hurries back into the cottage to manufacture an article exactly like mine.

Sir Melton Mowbray did not hesitate to grant me a day's fishing in his park when I met him in the lobby a month previnusly. I had rescued him from a deputation of farmers and churchwardens who were worrying him about some highway business, and I am sure he was grateful to me for the service. I, on my part, was equally grateful to him when he added that I might with surety anticipate some sort of sport, inasmuch as his lake had not been fished (to his knowledge) for three years.

It being now the Whitsun recess Sir Melton is at home, and receives me in a charming country house in the midst of an old-fashioned park laid out in some parts to resemble the best features of a natural woodland. Not fifty yards from the lawn I notice a hawk on the wing, and the rookery overhead is a Babel. The aged trees have been respected, and their picturesqueness, as I make bold to tell the baronet, is worth more to him than the felled timber. Wild flowers bloom upon the banks, and bramble and fern and bracken 
have not been removed if their presence suits the surroundings. The consequence of this is that Mowbray Park furnishes a perfect example of what Nature, assisted but not stamped out by Art, can do.

The lake is not large, but it is deep, and graced by numerous trees down to the water-edge along seven-eighths of its margin. Sir Melton Mowbray, introducing me to the water, wishes me luck, places a gardener's boy at my disposal, and goes back to his Blue-books. 'The only way of fishing the lake is from a boat, and boat there is none. There is instead an overgrown square washing-tub, used by the boy for fetching duck's eggs from a little island in the centre. You do not dare to stand upright in this remarkable specimen of naval architecture, but you may sit on a rail nailed across, and must balance yourself to a hair if you would avoid a capsize. Having procured a pole, I punt to the end from which the wind comes, and it is fortunate that it blows steadily, and not too strongly. . Then I deliver myself and fortunes to the will of the breezes.

Though I have been apprised that the Mayfly is out in unheard-of quantities, I can see none. Smaller insects are on the wing, but in spite of the rushes around the edges, and a thickly wooded ravine through which a tributary brook runs into the lake, the drakes are conspicuous by their absence. It is a game of patience, then, in which $I$ have to engage. I am aware that the Mayfly is quite as capricious as the rest of the insect creation, and disappears suddenly and mysteriously, without any apparent cause. In angling, too, it is safe never to take anything for granted. At the same time it is with just a modicum of faith that $I$ tie on a most elegantly made fly of medium size. The fish, I find, 
as I drift and whip, are very lively, and I get excellent sport for the space of an hour; and the trout are all within an ounce of the same size, each being about a pound and a quarter in weight.

This is a trifle strange, but so it is. A dozen and one of them lie in my basket, thickset fish; much yellower in colour, however, than I care to see, and as like as peas. It does not require very careful fishing to get them, for the wind assists you in the casts, and the trout take the Mayfly boldly the moment it touches the rippled surface, or not at all.

The wind drops, and the sun, letting a searching daylight into the bottom of the lake, reveals all its pretty traceried labyrinth of aquatic vegetation. Deep down, cosy amongst the weeds, I descry shoals of perch, and now I am no longer puzzled. In the mud no doubt there are eels also, and perch and eels, it is well known, give the spawn and fry of trout little chance. There being, as I conclude, few small trout in the lake, the heaviest fish have very likely fallen to my share. On the whole I have done passing well for so brief a time, but sport wholly ceases when the calm comes. The fish, however, are leaping on every hand, whereas before, when the remunerative fun was fast and furious, not a rise was to be seen. But every trout angler is aware that those frivolous splashes which make most noise and commotion are ominous signs-another illustration, in a word, of the adage "Great cry and little wool."

Until now I have frequently heard of perch taking the fly. Without going so far as to say I was incredulous on the point, I may here confess that I would not believe it except from authentic information. But there is no length of impudence to which a hungry perch will not go; and a humorous 
angler in the far west of Ireland once told me that the perch of Lough Corrib were, the moment your back was turned, in the habit of climbing up the banks, stealing a worm from the bag, and slinking again into the water to devour it at leisure. That may not have been true, but it was his story, and in return for it I gave him an appreciative laugh, and a pipe of tobacco.

These urchin perch to-day, however, rise madly at my Mayfly. I am whipping carelessly right and left as the wind wafts me towards the shore, and from a shallow part where the weeds are not two inches under water I decoy something which comes with a bang, and that something to my amazement is a perch. For the fun of the thing, and to thin out the undesirable companions of the trout, I lessen the number by a couple of dozen. The body of the fly looks like a fat caddis worm, and I put the folly of the perch down to that score, but adding a red spinner to test the matter, they still come and pursue both lures close to the punt. The teeth of the game little zebras of the water do not improve my Mayfly. The imposing feathers become ragged, then as perch after perch is caught the gauzy wings and long tail vanish, and finally there is nothing left but the half yellow half buff body, wrapped round with brown silk ribbing frayed and torn. This is a serious loss when, as I have discovered too late, there are but three Mayflies left in the book.

Sir Melton Mowbray at lunch promises to take my advice, buy a net, and remove the perch; and, beholding my good fortune, he betrays a sudden interest in the sport of angling, and carefully copies the address of the best tackle shop I can recommend. But the hon. baronet must build a proper 
boat before he begins, for the rickety washing tub was never intended to carry fifteen stone, and he himself confesses-and his park-hack would not contradict him-to that modest weight. I bid him good morning, and terminate my flying-might I not say Mayflying?-visit to Mowbray Park, not directly coveting my neighbour's goods, but perhaps resolving to think once, twice, aye, and even thrice, before refusing, should Sir Melton ever take it into his head to offer the place to me as a gift.

The sun smites fiercely upon us on our way to Brawl Mill. The road lies over a stiff hill country, and the valley of the Brawl is far beneath us, a lovely panorama of English scenery. The stream meanders through its course, a mere thread of silver from this distance. Two gentlemen, with a keeper in the rear, are whipping away, now and then resting to mop the perspiration from their foreheads, and appearing to us from our elevation no bigger than the Shem, Ham, and Japhet of a Lowther Arcade Noah's Ark. The driver knows them to be both peers of the realm; one of them owns the estate, and is a man of note in the racing world.

Every year at the first appearance of the Mayfly his lordship is telegraphed for wherever he may be, and the earliest train brings him and a companion or two to the nearest station. They take quarters at a roadside inn (where we halt to water our reeking horse) and remain there until the fly has gone, enjoying the sandy floor, the flitches of bacon on the rafters, the bunches of lavender in the drawers, and the fragrant snow-white bed linen. The only member of the party who seems put out by a temporary residence at this rural hostelry is the earl's valet de chambre: 
Mons. Adolphe has, I regret to state, taught the rustics the use of the word sacré, and saturates himself with eau de Cologne night and day, that he may not be polluted by the hinds and dairymaids about him.

Brawl Mill might be a bodily transfer from Switzerland, nestling there as it does in the silent hollow, with a slope of dark pines rising straight from its little garden on the hillside, with its drowsy old water-wheel, with its farmyard poultry and pigeons, with its wide porch smothered in roses, with its wooden loft steps, grey granary, and primitive outhouses. It is shut out from the turmoil of the world; not another human habitation is visible from the higher garden. It possesses two gardens-the first gained by ascending a flight of ashen steps above the mill; the second reached by similar means to where, below the house, the stream, after being released from the mill, tumbles over a fall.

Farther down the Brawl deserves the name I have bestowed upon it: it ripples and complains, it frets and hurries away to find its level in a water-mead beyond. Above the mill the stream is wide and placid, as if conscious of its usefulness in feeding the hatches communicating with the mill, and desirous of sticking to its post of duty to the last. A bank of impenetrable weed, filling half of the river bed, affords hiding-place for the trout, albeit it compels you to bring all your strength and ability into play to send your fly freely and gently across the stream; and a morass of rushes adds to the difficulty. The water is too clear, the sun is too bright; the fishable spaces do not give sign of a fin, and the flies alight and float down unnoticed. A stranger would not hesitate to pronounce the river untenantcd as an empty house. 
Ladies greet us here. I never yet knew the angler who regretted their society by the riverside, and there is one sauntering up the lane who has herself graduated with credit in bank-fishing. They have been rambling, and the children gleefully display the flowers they have gathered. Little Rosebud asks me to accompany her a field or two down the stream to pluck the forget-me-nots her small arm cannot reach. These sunburnt folks are spending their holiday at the old mill-house, and have much to tell me of bird, and beast, and fish.

Little Rosebud, let me inform you, has often aforetime been my companion at the waterside. She can distinguish a roach from a dace, and a trout from a pike, should the pike happen to be large enough, and she will trot along. proud as a queen if allowed to carry the landing net. So, yielding to the fair-haired tempter, I lay aside my rod, and stroll lazily along on the banks of the Brawl, inwardly making observations to guide me in the evening's fishing. Little Rosebud, it seems, has seen a kingfisher, and last night she heard an owl hooting in the pine-wood. A prostrate trunk invites us to spend an idle half-hour in a sweet natural bower, from which we can command a capital view of one of the best bends of the stream. It is the 29 th of May, and it is only meet and fit that the shadows overhead should come from the branches of the tender-leaved oak. Little Rosebud, flushed in the hedge-row out of theheat, sits crowned with flowers, clapping her hands at the large sportive Mayflies on the water. She thus receives. her first lesson in entomology, and hears the story of the nautilus, which the insects are imitating. They fall on the water light as snowflakes, spread out their wings like sails, 
and run free before the wind or gracefully tack, as it may please them. Little Rosebud claps her hands at the furious leaps of the trout, and shouts with very joy when the fly, after skimming daintily along the surface, and dallying with doom, takes wing once more and escapes scot-free.

But let us pass on. We will dwell no longer on this remembrance of a happy day; but should I live to the extremest span of human years, whenever the Mayfly appears in its season, the picture of little Rosebud in the shade, following the airy flights of the heedless insects, now up, now down, with her dancing eyes, will be ever before me, for little Rosebud, alas, alas, needs no more to sit in the hedgerow out of the heat.

The evening fishing repays me for the idle hour, and, to be honest, I meet with far more good fortune than I deserve. Above the mill, by the hatches, the placid current, when the day declines, is troubled with the movements of many trout. They appear to make no distinction between the insects that touch it. Drake or moth shares the same fate. My artificial Mayfly is quite as good as the plumpest reality. The ladies hover round, observing that fly-fishing. is a most gentlemanly pastime, and that a trout is entitled to special consideration as one of the upper ten of the finny tribes. I strike an attitude and resolve to treat my audience to something artistic. I dry the fly: one, two, three, and then for a cast that shall win a compliment and a fish. The great wings float trembling down to the verge of an eddy, and lo! a plunge and-CAlack, the cast rebounds with no fly at its extremity. I have by sheer stupidity lost both my compliment and my fish; it is the usual result of 
trying for too much, and the pinch of the mishap is that it has reduced my stock of Mayflies to a solitary specimen, with yet another hour of daylight.

That unfortunate trout will be telegraphing danger to all his relatives and acquaintances, unless he has darted into a quiet corner to persevere if haply he may rub the hook out of his jaws; in which operation I wish him speedy success.

It is better after this blunder to shift quarters for a few minutes, and take care that the fault does not recur. But how true it is that misfortunes do not come singly! Not five minutes elapse before a wild attempt at an impossible cast deprives me of my last Mayfly. I have left it driven hard into the overhanging bough of an alder that any tyro should have avoided. With varying success I now move up stream, picking out a trout here and a troutlet there with an orange palmer and a handsome blue dun. The still summer night steals on apace, and the half-hour remaining must be devoted to the broader part where the ladies witnessed my discomfiture. In point of numbers that half-hour turns out to be the most remunerative of the whole day; the trout rise freely at a tiny white moth, and are partial to a small coachman; twice I have a brace of young fish on the line at once.

The lower part of the stream I am compelled to spare, and even then it is dark before $I$ have arranged my spoil on a broad kitchen platter, artistically disposing the finest fish to catch the eye of the ladies chatting in the homely parlour of Brawl Mill. Supper being eaten, I plod up the creaking stairs, pondering that to tire the arms, stiffen the back, punish the right hand, develop the power of the 
lower limbs, and sharpen your appetite, you could pitch upon nothing better than a long day by the waterside in the Mayfly season.

\section{Practical Notes on May Fishing.}

Leaving out of the question the various sections of the salmon tribe which, with the exception of the grayling, are now in eager request, and the tench spoken of in the previous chapter, our fresh water fishes are, or should be, protected by the fence laws during May. Nothing is more difficult than to lay down fixed dates for the spawning of fish. So much depends upon the forwardness or otherwise of the season, and upon the peculiarities of different rivers, that the best authorities often differ upon the point. April and May, if not June, may, however, be safely regarded as closed months for all fish but those just mentioned.

This law is recognised by all properly organised Riparian authorities. In a forward season perch may possibly be fitting prey for the angler towards the end of May, and in our country districts, where each man doeth what seemeth him right in his own eyes, the merry month generally tempts the fisherman forth to open the campaign somewhat earlier than, according to the strict rules of the game, he should do.

As an example of the diversity of opinion amongst piscatorial Gamaliels take the following :- Walton did not commit himself to any particular time for the spawning of the perch, contenting himself with the very truthful remark that the fish will bite all the year round, but he hinted pretty 
broadly that it begins to be in season when "the mulberry tree buds, that is to say, till extreme frosts be past the spring, for when the mulberry tree blossoms many gardeners observe their forward fruit to be past the danger of frosts, and some have made the like observations of the perch's biting." Sir John Hawkins, who edits Walton, says (and very erroneously), "The best time of the year to angle for him is from the beginning of May till the end of June." Ephemera, who edits both Walton and Hawkins,' says, "Fish for perch from February to November"-thus giving at least three months (March, April, and May) when the fish is supposed to be preparing to spawn, spawning, or recovering therefrom. Hofland, whose "Manual," both as to text and illustrations, is a most trustworthy and genial handbook, says, "The month of March has been considered a good season for perch-fishing; but as they spawn in April and May, from that time they are out of condition till August." Blakey, no mean authority, comes nearest the orthodox standard when he says, "In March or April, and perhaps in May, according to the season, the perch cast their spawn, so that they should be suffered to nemain unmolested at least till July or August."

Not a word need be said here upon the modus operandl of perch-fishing; the fish is to be found everywhere, and everybody who has handled a rod knows how to take him. Classical, clubbable Jesse sums the case up very neatly in his "Rambles" by the borrowed lines :-

"Now let the angler that would fish for perch The turns in rivers and backwaters search. In deepest holes the largest perch you'll find, And where the perch is, kind will answer kind."

The perch is not popular as an edible because of the 
difficulty experienced in stripping it of its scales. There is no need to scale the fish at all; a perch boiled in his jacket will slip out of his skin with ease, and reveal himself white and firm, and, served up with parsley sauce, is well worthy of the praise of a past master in the Lodge of Epicurism. 


\section{CHAPTER III.}

\section{THE THAMES.}

"From his oozy bed

Old Father Thames advanced his rev'rend head, His tresses drooped with dews, and o'er the stream His shining horns diffused a golden gleam; Graved on his urn appeared the moon, that guides His swelling waters and alternate tides: The figured streams in waves of silver roll'd, And on his banks Augusta, robed in gold ; Around his throne the sea-born brothers stood, Who swell with tributary urns his flood: First, the famed authors of his ancient name, The winding Isis and the fruitful Thame."

CAN or will the queenly Thames be ever made a salmon river? That is the"question asked"year after year, to remain year after year unanswered. At times we are startled by reports from Thames-side of a salmon seen and nearly captured. During a whole season two or three years ago artful and exciting rumours reached town respecting a veritable salmo salar said to be creating a sensation at a certain station on the river. $\mathrm{He}_{\text {e was }}$ seen feeding every morning; Jack Rowlocks had obtained a full view of him as he leaped a yard out of the water in the summer twilight. So ran the story, and in various, ways that fish has ever since been employed to point"fishing morals and adorn waterside tales. He was evidently made to rise again in the following 
paragraph, which "went the rounds" at the beginning of the trout season of 1874 :-

"Yesterday morning a salmon trout was observed by a ferryman, leaping about in the Thames off Gordon House, Isleworth, the residence of Earl Kilmorey. It was supposed to weigh Iolb. or IIlb. A few days ago a salmon trout weighing 7 lb. $4 \frac{1}{2} \mathrm{oz}$. was captured by a bargeman off the island near the same place."

This narrative, however, unlike many other paragraphs worded in the same phraseology, had some real foundation. Reduced into truth, the facts were that a bargeman on the Surrey side of the river, opposite the Church Ferry, saw"had his attention directed to," I believe is the correct expression-a prodigious splashing in a hole which the retreating tide had converted into a small lake cut off from all communication with the stream. The bargeman proceeded to the spot, and forthwith interviewed the splasher, who turned out to be a slightly sickly but undoubted Thames trout of seven pounds weight. That it was not one of our old phantom friends we know from well-attested evidence, for the captor took his troutship to Gordon House, and Lady Kilmorey sent it to Mr. Brougham for inspection and verification.

Isleworth, perhaps it is scarcely necessary to add, is not precisely the region where you would look for these noble river aristocrats. You may in the hot summer time see shoals of dace and bleak in the cloudy water, and there is a tradition that within the memory of man a bonâ jide seal, straying far from the house of his fathers, was surprised at Isleworth, shot in the eye, chased from one side of the river to the other, and finally hauled out by his flapper. Flounders and eels also abide hereabouts, but trout are so rarely seen so 
far down that the capture of this unfortunate wanderer deserves passing mention.

Yet, after all, the Thames Angling Preservation Association has done so much towards improving the noble old river that we may well refrain from hazarding too positive an opinion upon the point. Certainly all that human exertion and enthusiasm can do is now being done, and the result is that for general angling the Thames, even in its palmiest state, was never better stocked than it is in these later days with the coarser kinds of fish. All thanks to the Association for good service rendered in the face of very lukewarm support from the public, who, nevertheless, eagerly seek a full share in the advantage.

Still, it is not high-treason, nay, nor treason-felony, to express the fear, even if in the expression we shock the feelings of Mr. Frank Buckland and his friends, that the Thames will not in our lifetime be a salmon river, unless, indeed, the fish can be introduced by a hitherto unknown channel. A salmon might survive Isleworth, but not the turgid "Pool" and its multitudinous shipping. It is probably almost forgotten now that the House of Commons in the reign of Charles II. passed a Bill whose object was the union of the Severn and Thames, and that by means of formidable and frequent locks and thirty miles of canal the communication was at length effected. Pope, writing from Cirencester, said he often dreamt of "the meeting of the Thames and Severn, which are to be led into each other's embraces through secret caverns of not above twelve to fifteen miles, till they rise and celebrate their marriage in the midst of an immense amphitheatre, which is to be the: admiration of posterity a hundred years hence." 
Could we not stock the Thames with salmon vit the Severn? Let us have a joint-stock concern to do it-- "The Severn and Thames Salmon Company, Limited." I make the commercial world a free gift of the gigantic idea.

The Thames, however, independent of salmon, does not receive full justice from the prejudiced public. Not long since, at the opening of the trout season, a leading article in a daily newspaper, with a sort of wink of the eye, humbly wished to be informed what had become of the good oldfashioned Thames trout; the insinuation clearly being that he was, like Messrs. Mastodon and Co., a thing of the remote ages. It so happened that during the immediately succeeding weeks most gratifying answers to that question came from many a fishing station. Yet it may be accepted as a fact about which there is no room for doubt that there has not been of late years - we have nothing to do with the olden times, when salmon were supposed to be numerous enough to hold crowded indignation meetings under London Bridge on their way to the upper waters-so many trout moving as in the season of $\mathrm{I} 874$. It is quite possible to bring facts and figures to support this position, but if I put them into the witness-box it would be chiefly that they might prove how highly beneficial and successful have been the labours of the Thames Angling Preservation Society, and the energetic officers who carry out its objects. During the first week in April, when the trout season opened, the anglers found little to do beyond shivering in the bitter winds and bewailing the high colour of the water; but according to that high court of appeal the Field, trout of goodly size afterwards began to be slain in various parts of the river with live bait, spinning tackle, and the fly, while one splendid fellow of.nine pounds 
met an inglorious fate by a night-line set for eels. In the middle of the month four hundred troutlings were transferred from the Sunbury rearing ponds to the Thames, and at Maidenhead there were numerous captures of the smaller fly-taking trout which so rarely come to one's basket.

Latterly, I hear that an effort is to be made to adapt the grayling to the Thames. It is indeed a consummation devoutly to be wished that the common brown trout and the grayling may establish themselves as regular householders of the river, many parts of which are eminently suitable for their peculiarities. But there are two determined enemies to the entire plan, if not more-namely, the pike and perch, and recent experience proves that these prowling bandits have multiplied exceedingly under the judicious rules enforced for their protection.

It is a little singular to read in an angler's book published forty years ago that while pike and perch fishing seemed to be followed only occasionally, "as it is very uncertain sport in the Thames," trout were fairly numerous. Then, as now, the proper thing for the angler was to perch upon the top of a pile with the uproar and gallop of the weir flood beneath him, and spin patiently for the expected monster; but there were spinners and trollers also in those days, piscatorial sons of Anak whose deeds were, and here and there are still to be seen, commemorated in the rudelyoutlined fish drawn on the walls of the comfortable hostelries on Thames-side. In s835 Jesse speaks of a large trout that took its daily airing opposite the water-gallery of Hampton Court, but had defied every endeavour to capture it. The wish expressed by Jesse that "something will be done for the protection of the fish during the earlier stages of their existence" has 
been fulfilled, and we can still say, with that rare old contributor to Fraser's Magazine, that "Persons of every class seem to participate in the amusement of Thames angling, from the Duke of Sussex to the little fat cobbler of Hampton." Jesse lived at Hampton, and naturally gave a preference to that portion of the river, and many modern anglers agree with him in that preference.

It was the Thames that inspired Jesse to recommend to his brethren of the Walton and Cotton Fishing Club the old song :-

"Come, lay by all cares, and hang up all sorrow, Let's angle to-day and ne'er think of to-morrow: And by the brook-side as we angle along, We'll cheer up ourselves with our sport and a song.

" There, void of all care, we're more happy than they That sit upon thrones, and kingdoms do sway: For sceptres and crowns disquiet still bring:

But the man that's content is more blest than a king."

Not so much as a trout river, however, as the cosmopolitan resort of miscellaneous anglers, let us bestow a few thoughts upon the Thames. I will openly confess myself a very indifferent Thames fisherman. Imprisonment in a punt has no delights for me. To me one of the chief charms of the angler's pursuit is the infinite variety of scenery into which it leads him. Give me a supple fly-rod, equip me in all respects in light marching order, introduce me to a few miles of stream that meanders through flowery mead and leafy dell ; that now rolls dark and deep, and anon splashes and foams over stones and shallows; that at every bend opens up a new prospect; that brings me here to a rustic weather-browned footbridge, and there to a ford through 
which the ploughman or harvestman takes his team ; or to a simple hamlet, perfumed with wood-fire, thatch, and homeliness, where morning newspapers are unknown; thence into the sheltered glade, and, by smiling homestead, away from the haunts of man; give me all this on a day when the larks sing loud and untiringly, and the insects rehearse in happy chorus; when "waves of shadow" pass over the glad fields and woods, and all God's beautiful earth seems to murmur in grateful softness of spirit-give me this, and you present to me one of the masterful attractions of what has been so appropriately termed the "contemplative man's recreation." I shall like it all the better, to be sure, if my fly be not cast upon the water in vain; but in no case shall I bewail the day as a positive blank.

This is a type of happiness which often falls to the rambling Waltonian's share, but seldom to the share of the Thames angler. Indeed, the only envy I can remember entertaining towards one of this fraternity was with respect to a gentleman who had the leisure, the patience, and the good fortune to whip his way from the source of the Thames through all the lovely landscapes of Gloucester, Oxford, and Berks, to the royal borough of Windsor, picking up a trout here, a chub there, and a dace you might almost say everywhere. Yet what exquisite scenes are commanded by the Thames! Verily it were a work of supererogation to recount them, since they have been the subject of poet's song and artist's pencil from time immemorial. Thus :-

" But health and labour's willing train Crowns all thy banks with waving grain; With beauty decks thy sylvan shades, With livelier green invests thy glades; 


\begin{abstract}
And grace, and bloom, and plenty pours
O'er thy sweet meads and willowy shores.

The fields where herds unnumbered rove,

The laurell'd path, the beechen grove,

The oak, in lonely grandeur free,

Lord of the forest and the sea;

The spreading plain, the cultured hill,

The tranquil cot, the restless mill,

The lonely hamlet, calm and still;

The village spire, the busy town,

The shelving bank, the rising down;

The fisher's punt, the peasant's home,

The woodland seat, the regal dome,

In quick succession rise to charm

The mind with virtuous feelings warm;

Till where thy widening current glides,

To mingle with the turbid tides,

Thy spacious breast displays unfurled

The ensigns of th' assembled world."
\end{abstract}

There are, I know, many anglers`who prefer streams on a smaller scale, and the liberty of the solitary roamer; but for the life of me I cannot understand why Thames punt-fishing should be sneered at and abused by those who have no personal liking for it. If to yield the greatest happiness to the greatest number is to benefit mankind, in the matter of angling the Thames punt must be held in supreme veneration as a benefactor. Thousands of citizens, for the major part of the year immersed in the grinding mill-round of business and business cares, thanks to the square-cornered ugly Thames punt, find innocent amusement and healthful draughts of fresh air.

Yet how easy it is to laugh at the spectacle, say, of those three stout gentlemen in their shirt-sleeves, sitting cosily in Windsor chairs, engaged throughout the livelong day in jerking back to their feet the gaily-coloured float which 
perpetually races away from them, as if anxious to escape the everlasting check put upon its motions! These gentlemen are Smith, Jones, and Robinson, and it is both probable and possible that they will be punted to the snug waterside hostelry at night with no more fish than they could hide in a quart pot. They are men in flourishing lines of business when at home, but to-day, happy as the kings of proverb, they sit there under the broiling sun, hoping a good deal, dreaming a little, eating, drinking, and smoking somewhat, and caring for nobody in the wide universe. Money may be tight in the City, markets bad, things on the Exchange gloomy; but for the time a lusty barbel or a wriggling roach would concern them more than all your dividends, discounts, or exchanges.

And there is no part of the Thames-certainly no portion of its fishable parts-where there is not shorewards something worth looking upon. No doubt your superfine critic would consider punt-fishing at Richmond, or anywhere between Richmond and Teddington, as Cockneyism of the most pronounced type; but if only for the sake of the manifold playings of light and shade upon the trees, the glints of golden sunlight falling each hour differently as the eventide draws on upon the river, and the ever-changing, ever-interesting traffic of the tideway which you get on a summer afternoon, stationed within sight of beautiful Richmond Hill, or further up by the pretty lawns and villas of Twickenham, you would do well not to think too lightly of a few hours in a Thames punt, even so close to the Rialto as are those near-at-hand "pitches."

It does your heart good to ramble along the banks and see how much happiness the bounteous river gives to old 
and young. Cockneyism? Sit down upon this bit of soft turf, your feet dallying with the meadow-sweet on the brink, and watch the inhabitants of the nearest punt. There is the fisherman in his usual commanding position-groundbait, gentles, landing net, customer's lines, and (may I without offence add?) commissariat department, all within reach of his hand. You see this is a family party. Paterfamilias in the straw hat will be at the receipt of custom tomorrow morning, and would politely but firmly request you to endorse your cheque if you had omitted that necessary ceremony. He watches the fisherman (who is generally Bob or Bill Somebody) dispense ground-bait much as yesterday he would watch the junior at the bank shovelling sovereigns into the bags; only he is free from anxiety, and the eye of the superior is not upon him. The two boys are absorbed in their sport, striking vigorously at the end of every swim, and clamouring for more ground-bait. Their mother, working quietly in the background, has to duck her head and lower her parasol when Master Henry perceives a bite, for Master Henry's idea of sport is swishing the fish high in the air over his shoulder. The little girl, lounging in the bottom of the punt, laughs musically at these performances; and the merry voices of all are never wholly still. '. Quite content are these anglers with the six-inch victims transferred, as fortune varies, into the basket.

What a hubbub there is in the punt when Paterfamilias after a dexterous "strike" finds his float doggedly held beneath the surface! The fisherman warns and directs after the manner of fishermen, doing, of course, his best to increase the nervousness of an inexperienced angler. Even mamma gets excited over this crisis. To right of them, to left of 
them, the taut line is borne. The angler is commanded to "let him go," to lower the point of his rod, and to take it easy. Miss Mary's oval face peers over the side of the punt, and her brown eyes try to pierce the two fathoms of water. Master Henry shouts aloud his conjectures. Master Robert saw the monster turn over on his side.

"It's as long as your arm, papa," he cries.

The float is gradually being coaxed above water at last, but it still makes sharp, slanting stabs, pointing to the depths where the prey, whatever it may be, is making angry efforts to free itself. It is a little disappointing, no doubt, when, after all this fuss, the monster is netted in the shape of a bronze, wiry .barbel, of not much over a pound and a half; but the consoling reflection remains that if it had been a salmon itself it could not have fought more pluckily. Our last glimpse at this scene of "Cockneyism" reveals the proud citizen surrounded by his family, to whom he is confidentially explaining that to slay such a fish with a footline of fine gut is a particularly clever and artistic feat-a proposition no one gainsays. Mademoiselle is much interested in the demonstrations of the barbel now sulking in the well, and the boys are busy separating their lines, which in the agitation of the last quarter of an hour were allowed to become entangled.

Young Browne Browne, Esq., pulling up stream with two brass-buttoned ladies in the stern-sheets, rests on his sculls to make game of Smith, Jones, and Robinson, in their shirtsleeves. He wonders how "these fellaws" can sit in the punt after that fashion, pities the weak intellect which angling denotes, and mightily amuses his pretty, gailydressed companions by his wit. It is strange that S., J., 
and $\mathrm{R}$. are on their part at the same time laughing at Browne Browne's amazing nautical costume; and Jones, who is the wag of the party, seeing plainly that the young boating-man is making himself pleasant at their expense, calls out and asks him why he does not take a reef in his maintop-sail anchor, and with shocking coarseness observes :

"I say, has the old man in Shoreditch sold that tripe business yet ?"

Whereat Browne Browne looks black, and one of his fair friends titters. I suppose life would not be half so tolerable if people did not spend a portion of their time in laughing at each other.

Browne Browne sometimes trusts himself on board a small toy steamer, and then he is apt to become a serious nuisance. The little spit-fire craft ruthlessly invades many a "swim," frightens scores of innocent fishing people who are unceremoniously

" Rocked in the cradle of the deep,"

and pursues its reckless way in triumph. And it would be all the better if Browne Browne would forswear that unmanly trailing propensity of his, and leave the small jack to reach years of something like maturity. I do not believe B. B., Esq., deliberately intends to be objectionable, but he is a thoughtless harum-scarum gentleman who does not look far enough ahead in his purview of the world and its waters.

The extension of railways has brought the Thames within easy reach of the angling classes. The river may now be "tapped" at all points, beginning with a Great Western station not far from the source. The number of anglers in 
the Thames multiplies with every season, and the pastime itself is more generally followed, if not in its higher, in its lower branches. The angling clubs in the metropolis probably have a good deal to do with this addition to the rank and file of anglers. As nearly as can be estimated there are close upon two thousand members of fishing associations in London, and half of them no doubt are Thames anglers. A very few of the clubs are high-class and wealthy; the rest are situated in poor localities, and supported by poor members. It would be too much to expect from the latter as high a standard of sportsmanship as you would find in the former, but as a rule the humblest societies are well ordered. When shall I forget the vision at Sunbury of a gentleman belonging to a crack club? I saw him in lemon-coloured kid gloves, followed by an urchin carrying his rod and basket. A stranger to the locality, anxious to fish for anything he could get, politely asked him a question or two as to where he might fish, and what his chances were of sport, receiving in return a supercilious stare through an eye-glass and a frigid

"Can't say, I'm shaw."

The stranger had his revenge afterwards. The gentleman seated himself on a post at the head of the weir, and remained there for three hours spinning, or rather allowing the rush of water to spin, for a trout. He did not catch the trout, but he fell headlong into the pool, and, besides being. half-drowned, lost his rod and spoiled his gloves.

The most courteous and genuine-hearted Waltonian I ever met by the waterside was a Bloomsbury locksmith's apprentice. I was stopping at Henley, and although I never actually indulge in my favourite amusement on 
Sundays, conscientious scruples do not prevent my watching with the keenest interest any sort of rod-work that comes under my notice on the day of rest. The first train on Sunday morning would bring down scores of rods, and most amusing it was to watch the anglers disperse along the riverside.

In the course of a few Sundays' quiet observation of these men, who mostly belonged to small angling clubs, I could detect signs of un-Waltonian selfishness, for which I suspect the club prize system-its abuse, not its use-is to a great extent answerable. Some "brother of the angle," as you might soon perceive, was stimulated by the hope of a prize to excel honestly in the craft; it sharpened his wits, and put him upon his mettle. In others, on the contrary, very undesirable qualities were developed. They forgot that though everything might be fair in love and war, in angling there are certain rules not to be transgressed. Their one desire was to bag fish-honestly if possible, but at all costs to bag fish.

The sportsman thus became, in the worst sense of the term, a pot hunter. He leaped from the railway carriage before the train stopped, panting to be first in the field. One morning I saw a dozen young fellows racing as if for dear life towards the meadows, foaming with rage at a dapper little French polisher who outstripped them all. Just as the peaceful church bells were calling the people to prayer, and the musical chime floated across the waters to die away in the magnificent woods rising grandly on the other side, a regular fight took place between the competitors. Throughout the day men tried to mislead and even to interfere with each other's fishing, a miserable contrast to the ancient 
angler who quaintly asked no higher bliss than to live harmlessly :-

"Where I may see my quill or cork down sink With eager bite of perch, or bleak, or dace ; And on the world and my Creator think Whilst some men strive ill-gotten goods t'embrace, And others spend their time in base excess Of wine, or worse, in war and wantonness."

My courteous locksmith's apprentice- $a$ thorough gentleman at heart-would hold no intercourse with these ne'erdo-wells. He had discovered a sweet nook at the junction of the main with a smaller stream, and there, hidden in overhanging alder boughs, he perseveringly plied his lures. The lad was very poor, and, as he confessed to me, denied himself all superfluities, and some necessaries, to raise the four shillings which his fortnightly trip to Henley cost him. He had never missed his Sunday for two seasons. He was. great in theories. He had a theory about everythingabout tying a knot, about impaling gentles, about striking and landing. His greatest achievement was the killing of a fine trout without running tackle and with an ordinary roach rod. Some club men refused to speak to him because he wore threadbare velveteen and highly bleached corduroy; but, as he informed me with a comical smile, they could be very gracious to the youth if they ran short of baits or hooks. With all their wiles and questionable play, the locksmith could beat them hollow at fishing. When to most eyes there was no movement of his porcupine float he would be fast to a fish. The prettiest bit of angling I ever saw was his handling of a vigorous poundand-half roach in a roughish stream. I have often wondered 
what luck has fallen to this casual waterside acquaintance in the every-day of life. He was very original, and, for one of his class, well-informed. A tattered readyreckoner, a fac simile of the famous Orton diary produced during the Tichborne trial, he always carried with him, as a receptacle of rare entomological or floral specimens. A present of a "Walton's Complete Angler" brought tears of gratitude into his eyes. It was not necessary to warn him, at any rate, against a certain selfishness which I fear, though not peculiar to Thames-side, is much more prevalent there than it used to be amongst Waltonians. Because of this I do not say the prize system should be abolished, but it is an additional reason why the humblest of clubs should cultivate a spirit which is fatal alike to unbrotherly and unsportsman-like behaviour. Surely, surely, anglers are so comparatively few and the world is so wide that there is room enough for all!

If the anglers who have not the opportunity of punting farther than Teddington or Hampton are to be congratulated upon the fair scenes surrounding them as they pursue their avocation, what shall be said of the more fortunate who pay leisurely visits to Windsor, Maidenhead, Cookham, Marlow, Sonning, Caversham, Pangbourne, Goring, Moulsford, and Wallingford? It is a very trite saying that we despise what is nearest home. One has no patience with travellers who persist in shutting their eyes to the beautiful scenery of the Upper Thames, or in placing her charms lower than those of other rivers, which they feel constrained to adore because they are more remote. The Thames, it is true, boasts of no bouldered bed, rocky banks, or turbulent currents that roar their troubled journey to the 
sea; but its landscapes in many respects have no equal. They tell in every feature of peace and plenty: of corn, and wine, and oil.

To the angler the Thames offers a wide choice. It contains fish for all fishers. Towards the close of last year's season I saw a dainty little lady, sitting in a punt near the bridge at Hampton, catch with most graceful skill a fine dish of gudgeon, who might truly have said :-

"And Beauty draws us with a single hair."

On the first Saturday in May a gallant friend of mine, snatching an outing at Maidenhead, caught a grandlyspeckled trout of five pounds, hooked a pike of ten pounds, which, under the extradition treaty of the fence months, was returned to the place whence it came, and in the same way and with the same result captured a chub of the unusual weight of six pounds. Of course while there are some prizes, I do not deny there are many blanks. That is a rule of life. In Thames trout-fishing there are, it is useless to conceal, many, many blanks; perhaps it is not too much to say that prizes are the exception. In the commoner fishing, however, the luck which falls to rods on the Thames, skilful and unskilful alike, is for these days, when the tendency of things is to destroy the remnant of sport that is left to us, amazingly great. Let any sceptic-and anglers somehow have to endure a maximum of undeserved unbelief - who doubts this betake himself on Sunday nights to the fishing clubs which encourage "weighing-in," and he will be surprised at the baskets of the coarser kinds of fish that are brought home from the Thames stations.

While the preservation of the Thames has been worthy 
of all praise, there is something yet to be done. Mede and Persian laws cannot be laid down upon angling, and the experience of one year, without any apparent reason, often directly contradicts the experience of another. But upon one point there need be no hesitating utterance-fishing for pike in June is opposed to both law and common sense. Roach may have recovered from spawning in that leafy month, though that is by no means certain, even when the season has been a forward one. In the last week of April I have caught with a fly dace that were perfectly recovered, and this in a stream where the previous year they were rough and flabby so late as the middle of May.

Leaving, however, roach and dace as debatable subjects, it cannot be too strongly set forth that the Thames anglers are allowed to capture pike a month, if not eight weeks, too soon. The bream-fishing of the Thames is capricious, but large fish are occasionally taken, and they are more delicately coloured within and without than the bream of sluggish waters. Tench are the angel's visits of the Thames. Perch, as I have pointed out in the notes to the previous chapter, are, as a general rule, fair game at Midsummer, for the perch, after spawning, loses no time in being himself again. It is the pike which suffers. Here again the prize system of the clubs works immense mischief. In June the pike are pallid and lean; at times you may take them with anything that is moving and bright, yet $I$ have seen them so emaciated and listless in that month as to barely move out of your way at close quarters.

Unscrupulous pot hunters in killing these fish are, to be sure, doing what is lawful; the expediency does not trouble them by so much as a thought. Every fish helps them 
towards that cruet-stand, or silver teapot, or twenty-two feet roach rod offered for the heaviest weight of jack taken during the season, or during a day; thus, however unclean their condition, the unseasonable fish are brought to the club scales. If the authorities with whom the fence regulations rest wish to damage the Thames as a pike river, in the hope of improving the trout preserves, that is quite another affair ; then, let us cut, and kill, and net by wholesale. But it is well known that such is not the case ; yet, for no reason that can be suggested, much less stated, pike-murder, allowed nowhere else in England, is encouraged in the Thames, which in other respects is being, as I have said, most carefully, and successfully, protected.

The professional Thames fisherman, though not half so bad as he is painted, is all the better for being looked after. Fishing from the punt necessarily involves an almost childlike trust in the fisherman. If you succeed, you reward him ; if you fail, you execrate him and all that is his. Your prosperity you place to the credit of your own skill; your adversity you lay to his charge. In both you may be right, but it is not hard to see that between the two the fisherman runs a capital chance of being spoiled. Much of the objection which many entertain to Thames angling arises from dislike of the fisherman. Still the fisherman's position is a safe one, for to fish the Thames profitably you must perforce use a punt or boat. The fishermen are capable of some improvement, although in fairness to them let me say that, considering how they are pampered by one set of anglers and bullied by another, the wonder is they are not worse than they are.

You will forgive a man much if he is equal to his business, 
and the Thames fishermen as a body do understand the river, and the habits and haunts of its fish. It does not of course follow that they will give every stranger the benefit of their knowledge; why should you expect them to be above favouritism and scheming when Society, from its Alpine heights of fashion to its plebeian base, is full of it? The fisherman, naturally too, sometimes loses patience with the amateurs who frequently occupy his punt; they are out for a day's jollity, and he fools them to the top of their bent. On the other hand, nothing can be more irritating than to be pestered by a talkative fisherman, or a man who will meddle and dictate.

Last year a friend persuaded me to join him in a day's punt-fishing at one of the higher stations. I was warned that I should find the fisherman a most disagreeable necessity, and the anticipation quite spoiled that pleasure of hope which every angler knows is not the least ingredient of a happy day. The man introduced himself to us at our hotel, and ordered breakfast at our expense-not at all bad as a beginning. Bottled ale was good enough for our hamper, but the fisherman, volunteering to pack the meats and drinks, coolly told us he could not drink beer, and must have whisky. A pint of Kinahan's was forthwith added for his special consumption; he was, I remember, particular as to Kinahan.

He punted us down the river, and brought up at a notable "pitch." Till then we had rather enjoyed the young man's cool, and not in manner at all offensive, assumption, but when he proceeded to forbid my companion to bait his own hooks, plumb the depth, or touch a fish; when a jack hooked himself upon my 
ledger line and I began, knowing somewhat of the process, to winch him in, and our friend peremptorily took the rod-my rod!-out of my hands, and by his clumsiness allowed the jack to escape, matters were brought to a crisis.

Some language ensued. The air, I rejoice to say, quickly cleared, and our friend was none the worse for the setting down he received, and for the remainder of the day a more docile, intelligent fisherman never wielded pole. He had after all acted according to habit; upon discovering that we understood our part of the business he devoted himself to his own. I believe we did nothing to boast of, but the two rods, in a day of six hours, produced $\mathrm{r} 6 \mathrm{lb}$. of honest roach. The fisherman was not at all a bad fellow when we came to know each other, but he had been spoiled by foolish customers, and required to be kept in his place.

Fly-fishing in the Thames, though the pursuit of a few, is a fascinating and not unremunerative method of dealing with the river. Though the fly is doing great execution amongst the trout compared with previous years, fly fishing in the Thames for trout alone is scarcely worth the time and trouble it involves. Dace and chub rise freely, and in the very hot evenings of July and August roach may be included. The fly-fisher is independent of the punt and the fisherman. A hired boat with a friend to manage it answers every purpose. Or an evening's moderate sport may be enjoyed from the bank if you understand where to go.

A boatman's boy below Ham Lane at Richmond with a peeled willow wand, a length of twine, and a small black gnat begged from some passing possessor of a fly-book, will, when the humour takes them, whip out dace with every cast. The Thames dace never runs large-four to a pound being 
perhaps under rather than above the average size. He is a game, handsomelittle fellow, and not to be despised as a table delicacy. Learn how to master the art of dace-fishing with your fly rod, and you have graduated to a full trout degree. Indeed, a quicker eye and lighter wrist are necessary for dace. The thing must be done on the instant if at ail. Should you, as I have had the felicity of doing in the Colne, find the fish feeding voraciously, and have a couple of bold half-pounders on your line at once, you may be ready to admit that, in the absence of trout, dace are not beneath an experienced man's notice.

Beginning at Ham Lane, and whipping your way to Teddington (taking care always to secure the tide at its first ebb), will afford excellent fun, wind and weather permitting. And the best plan is to use a short line, and, where the shallows cease, fish close under the bank. The natives-men in fustian and smocks-with the rudest of tackle, generally fish down the stream, casting with the left hand; and it is no uncommon thing to see them walk home with a pocket-handkerchief filled with fish that will make an ample and luxurious meal for their family.

Chub take a large fly well in the Thames, and the easiest road to their good graces is this : let your boat drift quietly with the stream-the slower the better-about a dozen or fifteen yards from the bushes under which the chub are known to congregate, and parallel with the bank. Use a large black or red palmer; drop it upon the boughs, and thence seductively into the water; and it will warm your heart to see how heartily the lumbering chevens rush to their destruction. Beware of the first bolt. Here, as everywhere else, it is the pace that kills. "Let him go"- 
that is always serviceable advice for an angler, although, in this instance, I must add a reservation. Let the chub not go into the bank or under the roots of a tree; should he accomplish that, invariably his first impulse, the chances are fifty-two and a quarter to one in his favour. The chub, nevertheless, is a chicken-hearted brute. He soon gives up the fight, and comes in, log-like, without a grumble.

\section{Practical Notes on Roach, Dace, and Gudgfon FISHING.}

I have selected these three well-known white fish for such few practical. remarks as may be made to supplement the foregoing chapter because they are best known to Thames anglers, especially such amateurs as in the summer months make angling a peg upon which to hang a water picnic, and because they are "the masses" of the Thames population. Barbel, chub, and bream will be treated of in a subsequent chapter.

Roach soon clean themselves in the Thames, and scarcely ever fail the angler who fishes for them with diligence and care. To do this the finest tackle is necessary, and drawn gut is now made considerably finer than the oldfashioned single hair. The strong probabilities of a lusty barbel, however, seldom allow of the finest tackle being employed, and in the Thames this is seldom so essential as in bank fishing, where the current is weaker and more even. We have long since got over the notion that the roach is a sheepish fish that any schoolboy may take. A skilful roach-fisher is not made in a day, and of a hundred anglers taken at random as they arrive at the waterside there shall 
not be a dozen who merit the title of really skilful. The Thames roach do not run so uniformly large as those of the Colne, but they are more numerous.

The London angler, when bank fishing, insists upon a long rod, a few inches of line only above the float, and no running tackle. When the fish are feeding timidly this apparatus will have an advantage over the longer line, shorter rod, and winch; but is it an advantage that compensates for the arm-ache and constant unshipping of the joints that are inseparable from the system? I opine not, and I have seen first-rate roach anglers who would agree with me.

Where the stream is swift, frequent ground baiting is an absolute necessity, but under other conditions, balls walnut instead of dumpling size should be used. Many a roach angler ruins his chances by overdoing the ground bait. Look after the material the professional fisherman prepares for you, lest lumps of white bread be concealed in the bran. Brandlings are a bad bait for roach; large lobworms in the winter often take the largest fish. The paternoster at such times will answer for both perch and roach. Houseflies sunk to midwater in hot weather are killing; artificial flies, small and finely tied, when the July sun declines will sometimes answer well, and when they do answer the sport may be continuous. Roach, however, are very capricious with the fly. The roach, when, say, a third of a pound in weight and river fed, makes a good dish of fried meat, and at some of the Thames angling inns the practised landlady can, out of the humble fish which most cookery books simply ignore, and to which others refer with disdain, perform a culinary triumph, making the soft firm, and the insipid passing sweet. 
The dace, or dare, is a bolder, as he is a handsomer, fish than the roach. Though less warmly coloured, and lacking the carmine fins which make the autumn roach a picture worthy of Rolfe's masterly pencil, he is thicker, rounder, and in appearance makes up in silver his deficiency of gold. When "on the feed" the dace bites almost as sharply as a perch, and as he loves rapid currents gives you even in bottom-fishing infinitely better sport than his broader-sided relative.

Wherever dace are found the fly-fisher has the elements of practice. From May to October, in warm weather, the dace rises respectably to a neatly thrown fly and the finest tackle possible to secure, and requires careful handling before brought to the net. Look for him upon gravelly shallows, and never give up the trial without using a dry floating fly. It is almost useless to fish deep water with a fly at any time of the year, and the Thames is not, by reason of its little broken or shallow water, so good a dace river as the Colne or Trent. From the Colne I have seen I6lb. of handsome fish, averaging three to the pound, caught with a small governor fly in the course of a day.

The dace is to my mind the best eating fish of the tribe. Carefully boned and baked in a jar, with alternate layers of spice, bay-leaves, and vinegar, a dish of dace was once palmed off upon me with complete success as a secret and rare delicacy. Pickling, after the manner of fresh herrings, in an open baking dish, is also a good method. It is very essential with roach and dace to dry them carefully before cooking. An enormous quantity of dace is sold in London during the Jewish fasts, for the table.

The gudgeon is a beautifully-marked little fish, and seems 
to be always in season. Its prolific nature entitles it to be termed the rabbit of fresh water, for there can be little doubt it spawns two or three times a year. Wiped very dry, enveloped with egg and breadcrumbs, fried crisp and brown, dashed with lemon juice, and eaten with brown bread and butter, it is renowned on the Continent as a delicious morsel, and, as all who have eaten it in that condition must admit, is well worthy of its high reputation. Moreover, it is easy of capture, and the lightest and cleanest form of bottom-fishing. Thus gudgeon-fishing on the Thames is a favourite pastime with ladies, who

"Feast on the water with the prey they take : At once victorious, with their lines and eyes They make the fishes and the men their prize."

In running water it is unnecessary to use a float, for the gudgeon grubs on the ground like the barbel, which it somewhat resembles, and may be followed with the stream, the line shotted according to circumstances. At Tempsford, on the Ouse, I was once given as a pike bait a gudgeon seven inches long. Four inches, however, is over the average length, and three-inch fish are quite large enough for the table. 


\section{CHAPTER IV.}

\section{A HOLIDAY IN DEVONSHIRE.}

"Fair are the provinces that England boasts, Lovely the verdure, exquisite the flowers That bless her hills and dales, - her streamlets clear, Her seas majestic, and her prospects all, Of old, as now, the pride of British song.

But England sees not on her charming map

A goodlier spot than our fine Devon;-rich Art thou in all that Nature's hand can give, Land of the matchless view!"

Devonshire, stealing into one's thoughts in the hot, unresting City, brings delicious suggestions. Amidst the dust of the desert it is the dream of a land flowing with milk and honey. The overworked man looks forward to its green lanes and luxuriant meads, to its cool darkened woods and refreshing streams, with a grateful sense of coming rest and freedom. Other counties have their special nooks and corners famed for picturesqueness and noted as the beaten track of tourists; large though it be, there is no other county in England bearing in its entirety so excellent a general character as fruitful Devon.

Announce that you are going down into Devonshire, and you have said enough. No one asks to what particular district you are shaping your course : so long as it is Devonshire you must perforce enjoy yourself. Does it not possess a soft, warm coast of surpassing loveliness, where the myrtle 
flourishes in mid-winter? Has it not gentle lowlands and bleak highlands? Does it not rise into open-browed moors that catch the earliest snows, and sink into valleys sequestered from the storms and turmoils that roughen the rest of the world?

These thoughts were not unwelcome as I stood apart from the shifting, bustling throng at Paddington terminus, mounting guard over creel and rods, until the express was ready to whisk me through the night to Plymouth. The confusion and bustle of this station, immortalised in Frith's picture, were positively soothing to the Devonshire-bound passenger, for the contrast between the fleeting present and the immediate future was a whetstone to the edge of anticipation. So, let porters and grooms rush hither and thither, ladies appeal in perplexing chorus to the officials, and testy gentlemen rage and scold-what mattered? Tomorrow I should be knee-deep in west country clover, my flies would be sailing down Devonshire streams, and for a whole week, behold, London should know me no more. The greater the hubbub around, the more placid I.

It was a long ride in prospect, for Reading, Bath, Bristol, Taunton, Exeter, and Plymouth had to pass in review ere I could exchange the iron horse for that more primitive carrier through whose good offices I hoped by to-morrow's noon to climb up into the free air of Dartmoor. It was the Ist of June, a date of no significance to ordinary mortals, though a red-letter day to the London angler. Wherefore, though perchance I should sleep by-and-by, it must not be until I had caught such glimpses as time would permit of the stations along the Thames. The Great Western is the angler's line par excellence. The Colne, the Thames, 
the Loddon, the Kennet, with their numerous feeders, are brought nearer and nearer to us as the powerful railway company, like an insatiable ogre, every year sweeps increasing territory within its capacious maw.

In a brief space of time the train was at West Drayton, where the mellow fading sunlight slanted across the Thorney Broad water, and revealed on the willow-lined banks rods flashing like bayonets. In a few minutes we crossed the narrow Iver, with just a glimpse, through the elms up the meadows, of the bridge, by which doubtless lay trout, over which since the first day of the season many a fly had been thrown. At Slough there might be seen upon the up platform a small contingent of returning anglers who had been honouring the Ist of June on the Thames at Eton. These were for the most part gay parties of young ladies and gentlemen who had been combining a large measure of picnicing with a soupcon of angling; who had been, in short, using the rod and line as a justification for and aid to flirtation. It was at Maidenhead, Taplow, Reading, and the higher stations the real anglers were to be found; there they clustered, leaning tired on their rods, recounting their day's experiences. And soon, the last bit of gold having been extracted by greedy nightfall from the sky, it was meet to settle cosily into the corner to doze, and see visions of speckled trout and silvery salmon.

The Dart, with whose upper waters I proposed to make intimate acquaintance with all speed, is crossed by the South Devon line at Totnes, and I had an opportunity of reconnoitring it at unexpected and unusual leisure. A deep sleep had sealed our eyelids as we ran down close to 
the estuary of the Exe and skirted the sea wall at Dawlish and Teignmouth; but we by-and-by became conscious of something uncommon, and awoke to find the train brought to a standstill in the midst of the purest country surroundings.

An hour or two before a luggage train had wrecked, and our passage was now stopped. In the freshness of the balmy morning we had-men, women, and children-to tumble out of the carriages, and struggle with bag and baggage through a couple of fields, across a country lane, and up a high bank of nettles and brambles, to a train composed of odds and ends of rolling stock, hastily constructed and despatched from Totnes. The ruined engine, getting off the line, had plunged madly into a field, torn up the earth a yard deep, and finally capsized, exhausted and smashed and twisted into a marvellous variety of fantastic forms. We arrived at last, fishing impedimenta and all, at our improvised train, panting, and with boots well yellowed by the buttercups. Being less than a mile from Totnes, I deserted my fellow passengers, left the few labourers who could be hastily gathered together transferring Her Majesty's mails and the contents of the luggage van to the new train, and strolled on towards Totnes, where the stoker of the hapless engine lay on a death-bed of excruciating agony. The sun, newly risen, shone upon this singular picture of wreck and confusion in a frame of rural fertility, and the sleek Devon herds and a few openmouthed rustics looked on in astonishment at the novel occurrence which had taken place amongst their promising orchards and richly-cropped fields.

The Dart at Totnes is a very sober-minded river. That 
morning not a breath of wind ruffled its greenish waters, and a couple of troutlets a hundred yards up stream, gently rising at a frisky midge, covered the whole surface with concentric circles. The trees and bushes in full leaf were repeated in the glassy water. North and south alike, the scenery is of the most fascinating description even here, where the Dart, having pursued its devious way from distant uplands, seems to pause for a brief interval of repose and thought before entering upon that magnificent, sweeping, more dignified course through the South Hams to the sea at Dartmouth. The Devonshire people are proud to hear the Dart designated "The Rhine of the West," and no unprejudiced voyager who has taken steamer from the ancient town of Totnes to the almost equally old seaport of Dartmouth will deny that the name is deservedly applied.

It is doubtless a very ill wind that blows good to nobody, and our delay had given me, at least, the opportunity of taking a leisurely look at the landscape. The railway guards and porters did their best to remedy the mishap; and in a surprisingly short space of time we were once more en route through the finest part of pastoral Devon. Every new prospect proves that it would be almost impossible to praise it too highly. The great officers of State take the Viceroys, Sultans, Shahs, and Czars of the earth to see our soldiers and guns, our forts and ships, our densely populated centres; but who ever heard of their being brought down into this Fden? Surely here was an aspect of the ration's life in which some, and not a little, of its strength was indicated!

But who cared for emperors and kings? Here came 


$$
\text { A HOLIDAY IN DEVONSHIRE. }
$$

South Brent, and running through it, with a bridge across, another Dartmoor-born stream, the Avon. Now I might form a pretty correct opinion upon the state of the rivers I had travelled so far to fish. For six weeks there had been no rain, and very ill reports of the rivers of the three kingdoms had been troubling the Waltonian world. The Avon was not encouraging; it was so reduced in volume that it was difficult to see where there was room for a trout, and throwing a fly into those mere saucers which now represented the best pools was out of the question. It was, one had to confess with sorrowful misgiving, a hopeless prospect, unless the banks of clouds brooding over the moors would come to the rescue and unlock their longsealed fountains. Anxiously I waited till a few miles further we crossed the Erme at Ivy Bridge. The Erme confirmed the dismal story told by the Avon. The stones in the rocky bed shone with the unwetted smoothness of a long drought. Although it might be better nearer the source, I began to wish that the creel, capable of stowing away 181b. of fish, had been left at home. Nasmyth hammers were not made to crack eggs.

But the woods were leafy, the air was charged with the scent of hawthorn blossom, the landscapes were magnificent, and if the worst must be endured, there would in all this be a certain compensation for an empty basket.

\section{" Nature never did betray}

The heart that loved her; 'tis her privilege

Through all the years of this our life, to lead

From joy to joy."

Still, remembering how the Erme and Avon in their average condition tumbled and swirled and gambolled from 
rock to rock, and beliolding their present melancholy dead level, it was but too true that just a trifle of sunshine seemed to have departed. Would the Yealm, yet another of the Dartmoor brood, dispel the cloud? Two or three miles further, and lo, the Yealm coincided with its sister streams. My only consolation was that in the same carriage journeyed to South Brent a young gentleman who was in worse plight than myself: three salmon rods, a huge wooden-framed landing net, fit receptacle for a shark; wading apparatus, gaffs, and an outfit generally that would stock a tacklemaker's shop, he had brought with him from town; and certainly he looked the picture of misery when I showed him the sort of brook upon which his costly machinery was to be exercised.

The valley traversed by the Tavistock Railway, to which at Plymouth we were transferred, is not to be surpassed, if indeed equalled, in this country for sustained sylvan beauty. I know of nothing to compare with it but the grand wooded slopes that keep you awake with surprise and admiration between Dieppe and Rouen. If the Plym valley be not so wide as that charming portion of fertile Normandy, its trees are larger and more numerous. Lord Morley's property at Saltram is the beginning of a stretch of woody hillside that continues with unbroken picturesqueness for miles. Such beeches, elms, ashes, sycamores, aspens, firs, maples, and oaks seldom indeed are to be looked upon from the windows of a railway carriage.

A few local anglers, who, it cheered the despondent stranger to think, would not have ventured forth unless there had been some chance of sport, got out at Bickleigh, and descended through the foliage towards the Plym, there 
almost hidden by over-spreading branches and bushy undergrowth. Higher up, losing themselves in the Plym, are the Meavy and the Cad-the Cad of which Carrington, the poet of the Devonshire waters, wrote :-

"Yet when, sweet Spring,

Thy influence again shall make the bud

Leap into leaf, and gentlest airs shall soothe

The storm-swept bosom of the moor, my feet

Shall tread the banks of Cad."

Both Meavy and Cad are good trout-yielding streams when the conditions are anything like favourable, but at this time they suffered more perhaps than any from lack of water. Onward and upward still, through new phases of entrancing scenery, the train proceeded to Horrabridge, where we crossed the Walkham, now no longer the popular trout stream it used to be ; for here unfortunately, as in other parts of Devon and Cornwall, the mines had been doing serious damage.

Tavistock, compact and thriving, lies in a natural basin, surrounded by a belt of hills; where Dartmoor ends the Cornish hills continue the duty of encircling the town, and dooming it to more than a full share of wet weather. The Tavy runs through it; and later in the year, when the salmon peel are in their prime, there is no river in the country that yields better morning and evening sport. A well-organised fishing association preserves the stream, its tributaries and sub-tributaries; and under one of its wise regulations the angler below Denham Bridge is restricted to the use of the artificial fly. It is in these associations the hope of preserving our English fisheries chiefly rests; wherefore, let every angler, whenever he has the opportunity 
of acting as an amateur water-bailiff, do his best to enforce their laws.

Eminently clean and respectable is Tavistock, on the border-land of the two great western counties. Nay, it is quite ecclesiastical in its"staid appearance. There is an air of repose within its borders of which you become immediately sensible. A rollicking blade the visitor may be in London, but at Tavistock it will be useless to struggle against the subduing influences around him. On entering the hotel I was on the point of doffing my hat, fancying I was on the threshold of a church. The markets had all the quietness of the cloister; the public buildings struck me as decidedly smacking of the cathedral style; and the police went their rounds with a verger-like tread. The town, celebrated in the fifteenth century for its mitred abbey, would seem to have cherished to the present day its ecclesiastical associations. Some remnants of the time-worn stone-work of the abbey are there, in keeping with the spirit of serenity which still lingers in the highways and byeways. Notwithstanding its demureness of countenance, Tavistock is a bright, comfortable, and right pleasant spot in which to pitch one's tent; furthermore, it is a central spot from which the angler may sally in many directions on trouting cares intent.

It is seven miles into the heart of Dartmoor, and, as you will speedily discover, seven miles pat against the collar. $\mathrm{He}$ who is able to ride and drive safely and boldly over Dartmoor is fit to take a horse anywhere. It is a typical drive from Tavistock to Princetown, for it affords fair examples of many peculiarities of the moor. Steadily ascending from the lowlands, the atmosphere, like the scenery, gradually changes. For the first mile or so out of 
Tavistock I noticed the foxgloves, in regular red-coated battalions, standing at ease in the hedgerows, while all descriptions of flowers were blooming in the profuse natural ferneries so common to Devonshire banks and woodlands. As the milestones were left in the rear, the foxglove bells became less open, until on Dartmoor they had not begun to expand into blossom. Up amongst the billowy downs, blocks of granite, wild ravines, shaggy sheep, and brawling brooks, we followed the road, now this, now that Tor challenging attention. Why this was ever called the Royal Forest of Dartmoor it is hard to say, although the bogs suggest forests primeval, and some years since no inconsiderable traces of tropical trees and plants were discovered in one part of the moors. It is the general absence of wood that is the primary characteristic of Dartmoor.

But then the place is a puzzle from first to last. The masses of granite, cast, apparently, in Titanic volleys out of the bowels of the earth, and the Tors crowning the summits of the downs, as if systematically placed there for specific purposes, may well account for the theories and superstitions and dogmatisms associated from time immemorial with them. The coachman - all the Devonshire drivers are civil and intelligent-pointed out the various objects of interest as our gallant grey plodded upwards. Pulling up at the top of the first hill, he bade me look behind. Tavistock appeared in its hollow like a snug bird's-nest. Cornwall, its hills crowned with mine shafts instead of granitic masses, confronted us. Far away over the end of a long, wooded valley, and sparkling like silver beyond the radiant woods, was Plymouth Sound. Ahead and around were the endless risings and fallings of the moor, now fresh and green; and 
the sun, fierce overhead, was printing cloud-pictures upon their broad bosoms.

I sounded a halt at Merivale Bridge, spanning one of those romantic rocky glens which intersect Dartmoor at every point. The Walkham, not yet polluted by the mines, passes downwards at this point. It is a good sample of a Dartmoor stream, plashing just then from point to point in. a quiet musical fashion, the banks open and bare, and the water clear_as crystal. It was, indeed, so clear that I on the spot abandoned my original intention of half an hour's fishing.

Besides there was other game on foot. A number of prison warders were abroad stalking convicts. Three of the wretches had escaped in a sudden fog that, enveloping the moor as with a blanket two hours before, had disappeared as suddenly as it came. The convicts had got away; two of them had been shot when the fog lifted, and the warders were searching for the third, examining every boulder, every peat stack, every bit of ditch and bog. Nearer Princetown we saw the warders bearing the prostrate runaway, number three, to the convict establishment, winged with a bullet from a carbine. Princetown is most desirable head-quarters for the angler, since it immediately commands several of the moorland streams; and there is admirable hotel accommodation for man and beast in the place.

To fish Dartmoor properly a horse is necessary for a man of only moderate walking powers, and if he be fortunate enough to engage for the term of his stay a moorland pony it will be a decided advantage. The man who can trudge fifteen miles a day may, however, consider himself inde- 
pendent of anything but a sensible pair of boots, and it should never be forgotten that there, more than $\mathrm{I}, 500$ feet above the level of the sea, fatigue is seldom felt as in the lower country. There is a comfortable little inn at Two Bridges, about two miles from Princetown, in a fine situation, and close to the West Dart and its tributary the Cowsick.

These Dartmoor streamlets, it may be convenient here to explain, have many, indeed most, things in common. Besides the larger streams there are, I believe, fifty brooks abounding in trout, but of them all these conclusions may be taken for granted:- the trout are remarkably small, delicious eating, and so plentiful that one is almost afraid to mention the undoubted "takes" that, with suitable water and wind, may be expected. As I had feared when once I had surveyed the chances from the railway carriage, my visit to Dartmoor, as a mere matter of fins and tails, was not profitable. The water had not been so low in the memory of our dear useful friend the oldest inhabitant; it was offensively pellucid; and, to make bad worse, the wind blew either north-east or not at all. Slimy weeds had accumulated in the pools, and nothing but a tremendous freshet would clear them.

Still with these overwhelming disadvantages, to which a bright sun may be added, and fishing, as on the last day (of course) I found, with not the most appropriate flies, it was easy to take an average of two dozen each day, and I might have basketed double that quantity on the first day had I known how small it was the custom to take them. The fish were verily Liliputian, even smaller than Welsh trout. One fellow weighed close upon half a pound, but 
that seemed of mammoth proportions amongst its brethren, and a three or four ounce trout was considered by the Devonians a highly respectable moorland fish. It is a well known rule in angling that when the small fish feed greedily the large ones do not move, and vice versấ; and the small ones had the ill taste to be in the ascendant on my visit to Dartmoor.

The bulk of the trout were about the dimensions of sprats, and these on the first day I in my ignorance returned to the water. Three or four, however, injured beyond redemption by the steel, went to the cook with what I deemed to be the sizeable fish. At dinner I made a discovery. The Dartmoor troutlets are the best flavoured and sweetest eating fish it was ever my good fortune to taste. You devour, or rather scrunch, them, body, bones, and head ; the much-lauded whitebait are inferior to them. A Plymouth friend afterwards told me that parties of gourmands frequently make expeditions to Princetown for the sake of a dish of petite truite. The quarter-pounders, though not to be despised, are at table less delicate than the symmetrical, energetic little things that at first so trouble the angler's conscience. A trout breakfast at the Duchy Hotel at Princetown, within sight of miles of moor rolling outwards to the horizon, is a treat to be often repeated; or if at luncheon time in the West Dart Valley you look in at the Two Bridges Inn, and selecting a dozen of the smallest fish from your basket, hand them over to the landlady, the chances are that twelve tiny tails alone will be left witness to your appetite.

I do not wonder at the fuss made a few years since about the convicts' diet ; Dartmoor has a special facility for making 
a man wolfishly hungry. Pick-me-ups are unknown in that village of stone, Princetown, where the houses, probably out of respect to the convict establishment, do not rise above the severest rules of architecture.

Four, five, and six dozen of trout are no uncommon result of a day's persevering and intelligent angling on the moors. An old man, whom I had no reason whatever to doubtfor similar statements were made to me by others-assured me that he once caught fifteen dozen in eight hours. This assertion will probably take away the breath of the incredulous heretic who shrugs his shoulders and drops the corners of his mouth at any record of rod and line work; but with very exceptional luck, or perhaps it should be said through a combination of fortunate circumstances, such an enviable capture is quite possible on the Dartmoor streams. Of course it will not often occur, and five or six dozen is the total which under ordinary conditions should give complete satisfaction, and send the angler home in good humour with himself, his tackle, the water, the weather-and, in short, the world at large.

Not even accidentally would I wish to do an injustice to the bonny watercourses of Dartmoor. I am far too much enamoured of them to be guilty of so flagrant a crime, and on this account $I$ would introduce a marginal clause touching the size of their finny habitants. After a flood you are never quite certain what will be tempted by the fly. Salmon are every year known to push their way up into the moor, and are seen in pools reachable by threadlike channels which to an unpractised eye contain scarce water sufficient to cover a fish. Large trout of two and three pounds weight are sometimes found when the water is clearing, but these 
are casual visitors never to be calculated upon. Late in the season the brooks swarm with salmon fry which worry the fisherman by their voracity. There are, or might be, plenty of salmon in the Devonshire rivers. At Tavistock I saw a report just sent in from the lower waters of the Tavy and Tamar setting forth that salmon and trout had never been seen in more abundance than during that season (1874), but that the mines were playing havoc with the water.

The Dartmoor streams should always be fished upwards. Their direction being, roughly speaking, from north to south, this course is the easiest as well as the best to pursue when the wind sits in the right quarter for piscatorial pursuits. It will save time and trouble to lay in a stock of flies at Plymouth or Tavistock. If one could make sure of finding that infallible native who generally lurks somewhere near the waterside, and who manufactures flies more killing and more natural than the living insect, he is the man to buy from; but it may happen that the worthy is not to be found, and life is too short to waste a day in unearthing him while the fish are eagerly rising. The flies at both Tavistock and Plymouth are excellent, and the shopkeepers thoroughly understand Dartmoor, and will give the customer honest advice as to the streams.

The knowing ones in Devonshire never use winged flies, and many of the niost successful fishermen go through the season with, at the outside, not more than half a dozen different hackles. Of these, the essentials are a blue upright, a red or red-and-black palmer, and a black fly, which for convenience sake we may also call a palmer. The coch-abondhu is not amiss, and there is a gaudy little fly called the Meavy Red, which kills well on the Meavy. A small golden 
palmer, used for grayling in the Wharfe, and given me a year before by its author, a keeper at Bolton Abbey, found me a couple of brace of trout in the Double Dart when the local flies utterly failed; and on the same stream I met a youthful rustic with a dozen and a half of nice fish (say averaging four ounces), taken against law, of course, with a live "vern-web," by which name the fern-fly is known in those parts.

The upper streams being very small and broken, the artificial flies used are, as is not uncommon in mountain streams, much larger than could be ventured upon in broader and deeper rivers whose flow is more placid. It is only once now and then that the Dartmoor angler encumbers himself with wading materials or landing net. A cheap day ticket may be purchased at the Duchy Hotel, entitling the holder to fish any or all of the Dartmoor streams. The Mayfly is a rare visitor, if not a complete stranger, to Dartmoor, and I complete my catalogue of items by a bare reference to Cherrybrook, which is a very favourite stream, and which is probably the only one in England that may be fished in a north-east wind.

Beginning at 'Two Bridges, fish the West Dart to the spot where the East Dart, amidst beautiful wooded scenery, joins. In the higher land, far above the meeting of the waters (Dartmeet), the two Darts run through unadulterated moorland; no bushes take a mean advantage of your carelessness, no trees are near. The outlook, if it were not so picturesque in its wild ruggedness, would be inexpressibly dreary; and to many visitors very likely Dartmoor is a howling wilderness, fit only for convicts, anglers, lunatics and-artists. It 
is a merciful dispensation of Providence that all men do not see with the same eyes. When, years gone by, we had prisoners of war who were confined at Dartmoor (the convict establishment was built for that purpose), a French writer described it as a terrible Siberia, covered with unmelting snow.

"When the snows go away," he added, "the mists appear."

In the desolation of winter Dartmoor is naturally not so pleasant as Torquay or Brighton. In summer, spite of the frequent mist, the Frenchman's description must not be entertained, for then the heather is everywhere abloom; the graceful ferns fondly sweep the edges of the great grey rocks; the foot sinks into an elastic velvet pile of moss, herbage, and alpine plants; the distant coppices catch and hold the shadows of the clouds in the trembling tree-tops; the colours of earth and sky imperceptibly change and blend morn, noon, and night; the cuckoo tells and re-tells

"His name to all the hills;"

the peewit, couched in the rushes by the brook, utters its shrill cry at your approach, and tries, with instinctive cunning, to entice you away from its nest; and there is music in the rarified air, performed by such united choirs as are made by myriads of merry-lived insects, the tinkling of streams, and the half-mournful cadence of many zephyrs journeying over the moors.

In sceptical mood I have sometimes doubted whether Mrs. Hemans, though she won the prize offered by the Royal Society of Literature for the best poem on Dartmoor, 
had herself looked much upon the place; but these lines are most appropriate :-

"Wild Dartmoor! thou that, midst thy mountains rude, Hast robed thyself with haughty solitude, As a dark cloud on summer's clear blue sky, A mourner circled with festivity!

For all beyond is life! - the rolling sea,

The rush, the swell, whose echoes reach not thee."

Near Dartmeet, woods begin to diversify the landscape. They cover the steep declivities that rise precipitately from one or both banks. Below the bridge there are numbers of the most tempting pools; but the local fishermen, admitting the superior scenery, give the sportsman's palm to the West Dart, which for a mile or two above the bridge is the beau-ideal of a lovely highland stream. Its bed is strewn with boulders that in drought, as in flood, irritate the impetuous current into ebullitions of boil, bubble, foam, and headlong plunges very beautiful to watch, and presently, when the torrent moderates into a less violent flow, most serviceable to the dexterous handler of the fly-rod. The Dart on its downward course to Buckfastleigh, more especially in its windings through Holne Chase, is the paradise of painters.

Time and space would fail me to recount the legends to which Dartmoor Forest has given rise. It was my privilege on one of my rambles to fall in with a gentlemam renewing an old acquaintance with the moors. For years he had been doomed to frizzle in the West Indies, and returning to the mother country for a year's holiday, repaired at once to Dartmoor to fish familiar streams and be braced by the invigorating atmosphere. Of course he 
was a sportsman, and accustomed to both rod and gun. We had whipped the West Dart, growing narrower and shallower every day, and then by common consent, meeting no reward, one day spiked our rods, lay down on the grass, and in the heart of Dartmoor smoked our pipes of peace like a couple of lotos-eaters to whom there was no future.

He knew the moors as the Londoner knows Fleet Street. He had shot blackcock in certain bits of scrub where a few regularly breed; he had tramped in the September days over the Tor far away to the north-east, returning at night with six or seven brace of snipe picked up in the bogs, and an odd woodcock or two recruiting on Dartmoor before starting for their inland haunts. He had ridden to hounds when the fox made straight over the open, up and down hills steep as the roof of a house. He showed me a cupboard in the inn at Two Bridges, where after two days' hard work on the upper moors he had deposited overnight two dozen of snipe that were to be despatched as presents to particular friends. In the morning, however, he was disgusted at finding the hearts carefully and cleanly extracted, probably by rats, from most of the birds, which were otherwise untouched.

Finally, after a true Devonshire luncheon of "bread and cheese and cider," he took me to Wistman's Wood. From the valley I had previously noticed what appeared to be a rather extensive shrubbery to the north-west of Crockern Tor. In the great heat it was a stiff climb up the slope, over which immovable blocks of granite lay thickly peppered. The shrubbery turned out to be a wonderful plantation of dwarfed, gnarled, uncanny looking oak trees, reputed to have been a veritable Druidical grove. The 
trees, though not more than seven feet high, put on all the airs of hoary forest patriarchs. In age they must have been the Methuselahs of their tribe; in shape they were the counterparts of the finest and most venerable oaks of Windsor Forest. Their branches were wrinkled ta such a painful extent that various plants and shrubs that usually prefer the ground seemed to have entered into a league to hide the marks of extreme antiquity from the light of day. Brambles, lichens, ferns, ivy, and other growths had taken root in the branches and covered them with tangle. The roots of the oaks, after centuries of fight with the granite soil, were doing their best either a few inches below, or on the exposed surface. Leaving this extraordinary spectacle we leaped the West Dart where it was a yard wide, and climbed the steep to the Cowsick river, gaining the high road through a wooded glen of the most exquisite loveliness, and passing a rude bridge of slabs said to have been put together by the Ancient Britons.

The Tamar, I had been informed, is generally fishable when other Devonshire rivers are dry, and to the Tamar I accordingly determined to go. This involved a sunsetand what a sunset!-journey back to Tavistock, a night's sleep in that quiet stannary borough, and an early drive to Horsebridge, six miles in the direction of the Cornish hills surmounted with tall chimneys. The experienced superintendent of the Tamar and Plym district had kindly "coached" me, but my ill-luck doggedly fursued me to the Tamar; the water was in good order, but the north wind blew dead down stream, rendering the likeliest scours and eddies almost unfishable from below. Wading and landing net were here indis jensable. 
The Tamar is a splendid river, with steep wooded slopes on either side, bed slaty with occasional boulders, of fair width, and it is one of the troutiest-looking streams imaginable. But my meagre basket would have satisfied even Major-General Incredulity. In two days only nine brace gladdened my eyes, but the trout were excellent representatives of the river-handsome, plump fish of two and a half to the pound, and game as trout of double and treble their size from some other counties I know of. The Dartmoor trout, like the denizens of all peat-bound streams, were dark ; the Tamar fish were perfectly shaped and beautified. I must confess to an indictable offence committed while thigh-deep in the Tamar. I caught and slew a young salmon, evidently a last year's fish. The unhappy victim took a black fly down his little gullet, and not surviving the surgical operation incident to the removal of the hook, gave up the ghost, leaving me and the superintendent to mourn his untimely decease.

The Inny is a tributary of the Tamar, and full of trout. Wading in the main stream should be done with care, for there are shelves which, without warning, will drop the heedless sportsman from five inches to five feet of water. The scenery at Endsleigh I shall not attempt to describeit is superb. The Duke of Bedford's lodge is perched up on the side of a finely wooded declivity, on which whole shrubberies of rhododendrons gleamed purple and lilac. The famous trees of Fountains Abbey are not more towering or wide-spreading than those in the Duke of Bedford's woods at Endsleigh. A little cottage maiden brought me a plate of brown bread and fresh butter and a mug of new milk at midday; and this meal, after laboriously whipping three 
miles of river in the teeth of the wind and against strong currents, was, I fancy, better appreciated than frequently happens with my Lord Mayor's turtle? and champagne at Egyptian Hall feasts.

Then was the time to use Golden Returns in a meerschaum service for dessert, and to take note of details. A hawk, caring no more for me than a Guatemala commandant cares for a British consul, swooped at a ringdove within pelting distance. Kingfishers flew by like flashes of sapphire and emerald; rabbits openly continued their nibbling in the next clearing; and the vermin-adders, my little handmaid said, were much too numerous-rustled in the intervening thickets. When a dragon fly pitched upon my ebony winch and crawled a few inches on a tour of inspection up my line, there was no more to be said-it was wonder-land pure and simple.

But musing is one thing and trout-fishing another. Standing out in the Tamar, a bit of shoal water landwards revealed to me all its treasures, and I recalled the minute description of Keats :-

"Where swarms of minnows show their little heads,

Staying their wavy bodies 'gainst the streams,

To taste the luxury of summer beams

Tempered with coolness. How they ever wrestle

With their own fresh delight and ever nestle

Their silver bellies on the pebbly sand !

If you but scantily hold out the hand

That very instant will not one remain,

But turn your eye and there they are again."

From the minnows, to be frank, I had turned my eye upon a gleaming, kingfisher, which fluttered through the brambles and ferns, and poised himself on a bough over- 
hanging the water, at which he looked intently while I looked at him. Meanwhile, a trout took advantage of my fly floating at will with the current, and rudely recalled me from my bird-study by hooking himself, leaping out of the water, and escaping with a shilling's worth of tackle. The kingfisher darted up stream, but came back again in a few minutes, hovering restlessly about, waiting, no doubt, until the neighbourhood was clear of his human rival. I rather suspect he was at the same time quietly amusing himself over the penalty I had to pay for inattention to rod and line.

\section{Practical Notes on Devonshire Fishing.}

The Exe, the Teign, the Otter, the Sid, and the Axe are good rivers in the more eastern parts of the country, the lașt three named coming in fact from the Somersetshire hills. The Otter is one of our earliest trout rivers, fishing commencing there with the month of February. It requires most delicate fishing, but there are fair supplies of trout. I have had no personal experience of these rivers beyond that performed by a spectator who sits in a basket chaise watching an angler, devoutedly wishing all the time that he wielded the rod instead of the whip. I saw a keeper near Ottery St. Mary catch a brace of half-pounders in two casts, delivered in the most masterly manner. But, as he confessed to me, he had been looking after those fish for three days. It is difficult to obtain permission to fish in this part of Devonshire. In the Exe, close to Exeter, there is a reach of passable pike water, fishable from a boat only.

In the north of the county the Taw and the Torridge are famous streams. The former is a Dartmoor born river, 
running fifty miles northward and receiving the Dalch, Little Dart, and Mole, all holders of trout. It becomes navigable a little above Barnstaple. The Devonshire Taw must not be confounded with the Tawe of South Wales. The Torridge rises close to, almost in, the source of the Tamar on the Cornish border, but, as if they had quarrelled violently at their birth, the latter runs south to the English Channel, the former north to the Bristol Channel. These north-going rivers have salmon as well as trout.

Slapton Lea, about seven miles from Dartmouth, is a lake separated by a spit of sand from the sea, and a favourite resort for pike and perch fishers, and after October of wildfowl sportsmen.

With respect to the Dartmoor streams, and those sufficiently near to be classed with them, the following details may be useful to anglers:-On the Tavistock and Launceston line the Plym may be reached from Marsh Mills, or Bickleigh, and at Shaughbridge the Cad and Meavy join, to flow together thenceforth as the Plym. For the Walkham, upper Meavy, and lower Tavy alight at Horrabridge. Tavistock is the station for the excellent fishing controlled by the Timar and Plym fishing conservators. The South Devon line touches the Plym at Plympton, the Yealm at Cornwood, the Erme at Ivybridge, the Avon at Kingsbridge Road and Brent, and the lower Dart and Harborne near Totnes. The Teign is within a short distance of Newton. The higher waters, as is shown in the foregoing chapter, are best reached from Princetown on the moor.

Flies, information, and licenses may be obtained from Jeffery and Son, or Hearder of Plymouth. 'In the late 
summer and autumn admirable sport may be obtained with salmon peel from three and four pounds downwards. After a flood the Plym"and; Tavy will yield heavy baskets to skilful anglers. As a rule season or day tickets may be obtained, but certain"portions of course are preserved by the landed proprietors. 


\section{CHAPTER V.}

IN THE MIDLANDS.

" The stately homes of England!

How beautiful they stand, Amidst their tall ancestral trees,

O'er all the pleasant land!

The deer across the greensward bound,

Through shade and sunny gleam;

And the swan glides past them with the sound

Of some rejoicing stream."

Hemans.

COWPER must indeed have been a poet to find so much in the River Ouse worthy of his attention. True, his was a humble soul, and very little gave him content. Musing and wandering he saw more sermons in stones, books in the running brooks, and good in everything than most men. The Ouse is an interesting river, but it is not romantic. It is prosaic and business-like from beginning to end, fulfilling its course through the fat broad pastures of Northampton, Oxford, Buckingham, Bedford, Huntingdon, Cambridge, and Norfolk, like a respectable commercial traveller who has to "work" a certain district, and is prepared to do it conscientiously to the last.

Cowper had a favourite expression for the Ouse. $\mathrm{He}$ called it "slow-winding." The poet was accurate: the river is slow, and I believe it pursues the most serpentine journey of all our rivers, through the flattest part of the. 
great grazing shires. Thus it fully justifies Cowper's repeated use of the expression referred to. He says :-

"Shut out from more important views

Fast by the banks of the slow-winding Ouse :

Content if thus sequestered I may raise

A monitor's, though not a poet's praise,

And while I teach an art too little known,

To close life wisely, may not waste my own."

In such words terminates the not half appreciated poem on "Retirement." Yet again the poet returns to his idea. He has not written many pages of his "Sofa" before he draws a picture of the river he knew so well and loved so much, which, like all his pictures of the country about Olney, is Wilkie-like in its fidelity to details :-

" Here Ouse, slcw-winding through a level plain Of spacious meads with cattle sprinkled o'er, Conducts the eye along the sinuous course Delighted. There fast rooted in their bank Stand, never over-looked, our favourite elms That screen the herdsman's solitary hut ; While far beyond, and overthwart the stream, That as with molten glass inlays the vale, The sloping land recedes into the clouds, Displaying on its varied side the grace Of hedge-row beauties numberless, square tower, Tall spire from which the sound of cheerful bells Just undulates upon the listening ear ;

Groves, heaths, and smoking villages remote."

This sketch is as faithful now as ever it was, and it is a description that may be said to apply not only to the particular district in which the poet lived and suffered, but to the general character of the river. Here and there the Ouse is not without picturesqueness, but there is always that fine suggestion of molten glass inlaying the vale. By no 
chance will the Ouse ever be taken into custody for brawling or riotous behaviour. When the rains descend and the floods come the Ouse swells, muddens, and overspreads the meadows in a methodical manner, doing its overflowing with dismal thoroughness, but conducting itself with persistent respectability, under circumstances which would warrant any other river in roaring and trampling over all that lay in its way.

In summer and in winter, going to Ouse-side with a pocket edition of Cowper in my pocket, I have, when sport failed, beguiled the time by following his minute observations of the scenery. I could give you the address of that boy of freedom of whom it is written :-

"To snare the mole, or with ill-fashioned hook To draw the incautious minnow from the brook, Are life's prime pleasures in his simple view, His flock the chief concern he ever knew."

The young rascal will get you a can of gudgeons for a consideration, and forsake his flock to accompany you on your piscatorial wanderings in the fields. And as you wander you shall be ever and anon reminded of the river's poet. By Sandy I have met that "reeking, roaring hero of the chase" who hunts that part of the world to this day. The little inn where you stay has its "creaking country sign," and "ducks paddle in the pond before the door." On every side "laughs the land with various plenty crowned." Many is the time when, smoking "the pipe with solemn interposing puff," I have stood "ankle deep in moss and flowery thyme," or taken shelter from showers under "rough elm, or smooth-grained ash or glossy beech," and in the absence of luck have returned "at noon to billiards or to 
books." Whether poor Cowper added fishing to his simple amusements has not to my knowledge been recorded, but you may remember how sagely he observes :-

"So when the cold damp shades of night prevail

Worms may be caught by either head or tail."

-an unvarnished statement of fact which leads me to suspect that the poet had at some period of his life been interested in that familiar operation to the angler of stalking "lobs" in the garden with a lantern and flower pot, having an eye to the bream to whom such dainties are an irresistible bait.

This pathetic couplet on wormology must be a reminder that this is not an essay on the poet Cowper, but a sketch of the river by which he spent so many years of his life.

The Ouse roughly speaking runs in a north-easterly direction. Rising in Northamptonshire, it for a while divides the counties of Northampton and Buckinghamshire, touching and indeed almost encircling the town of Buckingham, and afterwards, beyond Stony Stratford, receiving the Tove, which passes near the rare old town of Towcester and takes in the drainage of Whittlebury Forest. At Newport Pagnell the Ouse is increased by the little Ousel, then flows on to wooded Weston, where stands the park placed at Cowper's disposal by his faithful friends, and to Olney, where he lived in neighbourship with John Newton, of Olney hymn fame. By-and-by it comes to Bedford. At Tempsford it is joined by the Ivel; it becomes a broad, deep river in Huntingdonshire, takes in numerous minor streams in its course through the Fen Level, and after $15^{\circ}$ miles of persevering twisting and turning delivers up its. tribute in goodly volume at the estuary of the Wash. 
The Ouse is an excellent pike river, and remarkable for the size and quantity of its bream. For the greater portion of its length until recently it was under no law but that most wholesome law of trespass, which, judiciously enforced, is so. potent a preserver of wood and water when other provisions. fail. And there is probably no stream in England which has been more poached than the Ouse. It has been long a recognised custom for men, armed with nets madeafter a fashion most suitable for the purpose, to undertake a tour as regularly as the spring comes round, and, placing their abominable traps across the mouths of the brooks, to drive down from the long watercourses the fish which havepushed their way up to spawn. Literally nothing comesamiss to the net so used; and as in the level country the little watercourses are narrow and deep and frequent, the brooks and ditches are capital breeding grounds.

A gentleman last March in Huntingdonshire, riding leisurely home after a day with the hounds, leaped one of these yard-wide watercourses and started a poacher who was hiding under a bush. The marauder had been using the net above described, and in his dirty sack were several pike of about two pounds' weight, and one fine fish of over twenty-four pounds, quite out of condition and heavy with spawn. To be sure the rights of property must be preserved, and if the farmers and other occupiers of the land have no. objection to this sort of fish murder there is nothing more to be said.

But that spirit of preservation which in a former chapter I mentioned as so beneficial to the Thames is not confined to metropolitan head-quarters. In all parts of the country, rivers, to foul and poach which the public from time- 
immemorial fancied they had a prescriptive right, are being protected by local societies, and although there is generally some sort of opposition at first from the obstinate and meddlesome wiseacres who imagine themselves called upon to be village Hampdens at every new proposition, however trifling it may be, before long, the innovation proving itself an improvement, is warmly accepted and supported. Nothing would be more reprehensible than the shutting out of the public from opportunities of enjoying the delights of angling, and as a rule this course is scrupulously avoided. Wherever these associations exercise jurisdiction you find a certain stretch of free water as to which the only restrictions insisted upon are those which are necessary to good order and fair play.

Here let us return to the Ouse. Formerly the river in and near Bedford was worthless to the angler, but it is now most sensibly prescrved by the Bedford Angling Club, of which Mr. Howard, the famous implement maker, is president. The most valuable rule the club has passed is that which leaves the jack unmolested till September, up to which month Master Luce should unquestionably be allowed in most waters to fatten himself for the sacrifice. Again, the club permits no fishing on Sundays, and the "free water" in the centre of the town must be fished under the eye of the keepers.

In a year or two the Ouse between Bedford and Barford Bridge-within three hours' reach of London let it be remembered-will be first amongst the pike waters at our disposal. Fish of ten and twelve pounds are abundant in the long sluggish reaches, where the water is frequently fourteen or fifteen feet deep, and seldom indeed should an 
angler return without a brace or two of good pike. Towards the close of last season, in a North London angling club, a tray of pike was exhibited as an illustration of the value of the Ouse : there were two fish-a handsome pair, alike as two peas-of nine pounds and a half, four between five and seven pounds, and three not much above or below four pounds. That was the reward of one short winter-day's live-baiting three miles or so below Bedford.

Two autumns ago I myself had the pleasure of finding a "hot corner" amongst the Ouse jack. If I had a Cowper in my pocket, there was despair in my heart. Two days had I been sojourning at a pleasant waterside inn at Barford Bridge, a melancholy example of the strange reverses to which the angler is subjected. The "tip direct" had been sent me that the pike were feeding, and off I went straightway to Sandy by train, and to Barford per dogcart, with a companion who meditated valiant deeds with his bait can. Even while alighting from the two-wheeler-as a matter of fact my companion, encumbered with three rods and little short of half a hundredweight of miscellaneous baggage, tumbled out head foremost, and smashed the baiting needle he had ostentatiously stuck in his hat-we saw an urchin, wielding a clothes prop and line to match, swish out a pikelet close to the bridge : and rubbed our hands at the prospect.

But the entire day was a blank. Somehow the fish "went off," and fed not. Perhaps the wind had chopped round to the east; perhaps the fish knew, as they are said to do, that atmospheric changes were pending; perhaps they had retired into the magnificent thickets of tufted reeds which rose like a wall out of the other side of the river; perhaps 
the sportsmen were not sufficiently skilful with their lures. Anglers are often laughed at for that ready excuse they have under any circumstances and at all times to explain ill luck : the water is too low or too high, too bright or too coloured, or the weather is unfavourable, or has been, or threatens to be so. Nevertheless, laugh as you may, it is undoubted that fish do suddenly and without any apparent reason drop into listlessness and lie at the bottom like a stone, to be tempted by no bait whatsoever.

On this morning we tried every expedient; roach, dace, and gudgeon were in turn placed upon the live bait tackle; every spinning flight in the box was attempted; artificial trout, phantoms, and red-tasselled spoon bait succeeded; and finally we settled down to-what is after all the best method of fishing the Ouse-trolling with the gorge bait. A dozen times during the day we distinctly saw pike lazily follow the spinner or dead roach to within a few inches of the surface, never intending-the cheats!-to touch the bait, but pursuing it out of mere shark-like instinct. We thus returned to our hostelry, muddy, silent, out of heart, and hungry; and stamping our feet at the door confronted the country postman.

There he was to the life as drawn in "The Winter Evening." We had heard his horn twanging o'er yonder bridge while we passed through the third meadow with the rods slanting over our shoulders. He was the poet's "post" with but a few touches of difference. The boots were spattered, and the waist strapped as of yore, but his locks were not frozen for an obvious reason-it was not frosty weather; and

"He whistles as he goes, light-hearted wretch." 
We did not whistle as zue went, and I have already intimated that we were not exactly light-hearted. Not at any rate until we had plodded upstairs into our snug sitting-room.

Ah! what a friendly friend a blazing wood fire is! How the flames seem to wink at you, and how the crackling and sputtering suggest somebody [laughing] and nudging you under the fifth rib! Why, a ten pound note, or three fives at the outside, would have purchased the entire furniture of that cosy room, outside of whose window the sign swung and creaked. But it was a palace to us, though the branches scratched the window as if they were angry fishwomen clawing at a husband's face. There was a storm brewing south-eastward, and the rising iwind made mad work with such few leaves as were left upon the branches, while the day faded out in the sullenest of moods.

What more suitable time for relishing the warm chamber, loose slippers, cleanly spread tea-table, and savoury ham and eggs! We made love to the Dresden shepherdess in china on the mantelpiece, and admired the cheap hunting scenes on the walls; and as, tumbling out the winches to wind the sodden lines round the chair backs-never neglect that precaution, Mr. Pikefisher-we tumbled also the Cowperian pocket edition out of the wallet, what more natural than that, thawing into good humour, we should hold forth in recitation?

My companion, the "Gay Comrade" of our first chapter, rather prides himself upon his elocutionary gifts and graces. The shadows of the wood fire flickered about his curly head in the darkening room, as he extended his right arm and in commanding tones began-

"Now stir the fire, and-" 
Margaret of the ruddy cheeks and white apron at that precise moment silently entered, bearing candles; with a little shriek she observed :-

"Oh, no, sir, please don't ; them logs churkle dreadful, and the sparks 'll pop out and you'll burn the carpet if you poke the fire."

The G. C., somewhat abashed at being caught in a tragic attitude, at my laughter, and at being so ruthlessly brought down into the ham-and-eggs atmosphere of every-day life, pierced the poor woman straight in the eyes with a fearful glance of Othelloish, Macbethical, and Hamletian power. Then he resumed:-

"And close the shutters fast, Let fall the curtains, wheel"-

"I'll try," quoth Margaret, " to fast up the shuts, but I know two of the hinges is broke, and the blind don't come only half ways down."

The reciter here found it convenient to gaze vacantly out into the gloom and hum something until the handmaid had descended into the lower regions, and then good humouredly, and with a fine sort of frenzy in his expression, he finished the broken measure :-

- "wheel the sofa round,

And while the bubbling and loud hissing urn

Throws up a steamy column, and the cups

That cheer but not inebriate, wait on each,

So let us welcome peaceful evening in."

We forthwith welcomed according to our lights. The sofa, weak and ruptured in the hind off castor, refused to be wheeled; the steaming column arose, not from the dear old 
urn now so seldom seen, but from the hot water jug doing duty as a reserve force to the teapot; and to be honest (poor but honest as the story books have it) the cups were not quite so innocent as those handed round in Mr. Newton's Buckinghamshire Vicarage or Mrs. Unwin's parlour, for, as a precaution against cold - and understand, once for all, from no less praiseworthy motive-our tea was flavoured with just a suspicion of cognac, which increased the cheering quality without producing actual inebriation.

It is Cowper's fault that by this time I have almost forgotten my "hot corner" experience on the Ouse. I apologise and pass on. The morning after we had welcomed our peaceful evening in-do not fear, I really will not wander away from the point any more-it blew a gale, and we had not been out of doors five minutes before we were drenched. At length we got a mile or two down the stream, but the blank of the previous day was repeated. Like those very old fishermen we read of, we toiled all day and caught nothing. The sun began to set in a copperclouded and wild sky about five o'clock, and in the midst of a discussion as to whether we had not better go back to welcome another \&c., the wind fell-soughed convulsively amongst the quivering forest of reeds, sighed, and went to sleep.

Now was the time. A lively gudgeon cast within a few inches of an island of rushes in the middle of the river did the trick; in a twinkling the float darted away and the winch spun round merrily. In all directions the small fry, leaping out of the water and fluttering on the surface, betrayed the whereabouts of the ravenous fish. Released from the mysterious spell laid upon them to our loss during the two 
previous days, they now appeared to throw caution to the winds. As fast as I rebaited, my float disappearerl and a fish came to bank. Who shall account for the unaccountable? The G. C. is in all points a better angler than myself; his tackle was finer and his style of fishing more artistic. Yet, when too dark to see the river we reluctantly reeled up, his bait had not been touched, though half a dozen pike taken in the manner I have described by my rod were hopping about in the grass. It was all the more singular because my friend had thrown his baits into places where fish were visibly moving, and where directly he shifted his position I was instantly successful.

In July and August there are almost miraculous draughts of fishes amongst the bream in the Ouse. Not a hundred yards from Bedford Bridge there is at least one bream hole out of which sixty pounds of fish have been taken in a morning, and you hear of bream of six pounds. That, however, is an extraordinary weight, but a three-pound fish is not at all uncommon in any part of the river. I must confess to no great respect for the Cyprinus Brama. A fish that is shaped like a bellows, that is as thin as a John Dory, that is as uneatable as the John Dory is delicious, that is capricious in his habits, and that rarely rises at a fly, cannot be termed beautiful or useful to either cook or sportsman.

In the Ouse country, notwithstanding his bones and general insipidity, the poorer people do eat the bream and like him passing well. At Huntingdon on one of my outings by the Ouse the landlady of a small inn served up a breakfast dish which I relished to the extent of absolute consumption. It was a thin fillet of white fish, from which 
the bones had been extracted, and which was served up yellowish brown with some description of savoury herb sauce. Having eaten every flake, upon 'inquiry I found it was the bream I had on the previous night so execrated. But I freely confess frequent trials since have utterly failed to make the bream a decent edible. Yet I do not forget that the French proverb says, "He who hath bream in his pond may bid his friends welcome," and that Chaucer, who may be said to have known a thing or two, wrote:-

"Full many a fair partrich hadde he in mewe, And many a breme, and many a luce in stewe."

A recital of a little personal experience_of bream-fishing will give some insight into the habits of the bream. Having at odd visits to John Bunyan's pretty and interesting old country town seen Howard's workpeople returning home staggering beneath burdens of fish taken from the bank in the meadows near Cardington Mill, I resolved to lay myself out seriously for rivalry: but unfortunately it was October before I could carry out my intention. This I did not require to be told was fully a month' or six weeks too late; but a celebrated professional, bream-catcher at Bedford, nevertheless, got his boat ready and took me a couple of miles down the river. We tied ourselves to the reeds with fourteen feet of sluggish water beneath us, and to our dismay found the surface smooth and clear as glass. The bream angler in July should be at his post on the river and quiet as a mouse by daybreak, for the chances are that he will have finished all his work by breakfast time. But as later in the season it is necessary to let the morning chills evaporate, eleven o'clock had struck before we began.

Balls of mingled slime and brewers' grains the size of 
bombshells were first cast into the water five yards from the boat, the boatman observing-

"You'll see a lark presently, guvnor." He then began to make ready his tackle--long, heavy, rudely made rods, coarse lines without winches, clumsily leaded gut hooks, and seven or eight nasty little worms affixed en masse to each hook, of which there were two to each line.

"Why don't you throw out?" I said, all being ready, and looking out upon the dreadfully unruffled surface of the broad river.

"You hold hard, guvnor; there'll be a lark presently," he still replied, looking down the stream with a patient, wistful gaze.

"There they are," he said, by-and-by; "don't move, guvnor. I know the beggars, bless you-I told you so. You keep still, guvnor."

He now made a monster cigarette from a leaf of Bradshaw's Railway Guide (having forgotten to bring out his pipe and tobacco), and watched what he had termed a "lark" with a benign expression of countenance. It was certainly amusing. Quite fifty yards down the river large dark somethings splashed, twisted, and plunged upon the surface of the water in hundreds, all advancing slowly towards the point where we were stationed. This the boatman said was a favourite winter-home of the bream, and his theory was that they had scuttled away in shoals at our approach, and were now slowly returning in good skirmishing order. Steadily the host advanced, the splashes and backs of the fish appearing at intervals of four or five yards. The signs ceased when they should have appeared opposite our boat, and this led the bream master to remark- 
"The darned skunks, they've winded us, guvnor."

Be that as it may, in a few moments the hubbub recommenced many yards above us, and then all was silent as before. After a decent pause, the bream having evidently retreated upon their former position below, the plunges began again, and another cautious upward movement commenced; and to our delight this time there were no indications that the fish had passed us.

The boatman then deftly threw out his baits and fixed his rods under the thwarts, and I followed his example with my lighter implements. Five minutes elapsed, when down went both of his floats. They came up, went down, came up, and again went down, while the fisherman grimly sucked his Brobdingnagian cigarette. Soon a decisive slanting movement of the long float led him to strike sharply, and his great rod bent to the encounter. Two or three struggles appeared to exhaust the bream, and they were netted in succession without much finessing or trouble. My companion thus caught seven fish in the course of an hour. Then my turn arrived. To my chagrin I had been wholly unable to throw my delicate tackle out to the baited ground, but now the porcupine quill went clear away at a shoot; to be brief, the drawn gut parted at the sullen resistance to the too eager strike, and the boatman, emitting a great oath, said we should get no more sport.

"If it had been summer," he said, "it would not have mattered so much; we should have whacked 'em out like a shot ; but it's all up now."

And even so it proved.

The processes necessary to successful bream-fishing, like those insisted upon by barbel-fishers, are not nice. Ground 
baiting hours before you fish is a necessity. Great fat lobworms, or unsavoury brandlings, are the orthodox bait, and the fish himself is covered with slime that is not pleasant to handle. No angler would care to fish often for bream if there were other fish within his reach, but in Bedfordshire and Huntingdonshire men of the artisan type manifest a rooted affection for the sport, and wherever bream exist, having found the same predilection, I always look upon the broad, fork-tailed, 'light brown bottom-grubber as a kind of working man's candidate.

Hard by a village $I$ once visited in Yorkshire there ran a canal in which there were a good many bream. Amongst the men who at about"six feet intervals lined the banks on a summer's evening was a quaint, shrewd Barnsley pitman, with whom I became very familiar. He would think nothing of a fourteen miles walk for the sake of three hours with his pet bream, than which, he firmly believed, no nobler game swam the water. He was a consummate coarse fish angler, and a hero amongst the Yorkshire Waltonians. Poor fellow ! Years passed, and I had forgotten him. Then I saw him, blackened and dead, one of a ghastly row of unfortunate colliers just brought up from a pit, laid out on benches, and ticketed, till the coroner should inquire into the miserable circumstances which without warning cut them off from the land of the living.

Before taking leave of the Ouse I ought to add that it contains other fish than bream and pike. Perch of two pounds and upwards are often caught, and the anglers who give themselves entirely to perch-fishing will not allow that the Ouse is second to any other stream either as to the quantity or quality of the bold, handsomely decorated fellow 
which we all know so well. I have slain heavy baskets of fair-sized perch-that is to say, three-quarters of a pound or thereabouts - under the railway bridge across the Huntingdon Racecourse, and I took there close to the bank one of a pound and a half, with a mere scrap of worm. Chub are common in the Ouse and afford good evening sport with the fly, and roach of course swarm in such a stream : eels likewise. The Bedford district I have mentioned because it is nearest London, but there is good angling for pike in the Ouse along the five or six miles of which St. Ives may be made the half-way house.

Without intending to be disrespectful or unfaithful to the queenly Thames, I must profess an undying adoration of the Trent, the many-armed Trent that takes much of its inspiration, if not its source, from the breezy highlands of Derbyshire. It is a kingly river, and terminates its long stately journey by mingling with the waters of another river, many-armed and mountain-flavoured as itself-the Yorkshire Ouse. The only resemblance existing between the Ouse of the Midlands and the river which is supposed to be the north and south division line of the kingdom is that each has its poet. Cowper sang of the Ouse, Drayton and Kirke White of the Trent. Drayton, adopting a prevailing legend, has a somewhat off-hand way of accounting for the word "Trent":-

" There should be found in her of fishes thirty kind; And thirty abbeys great, in places fat and rank, Should in succeeding time be builded on her bank; And thirty several streams from many a sundry way Unto her greatness should their wat'ry tribute pay."

Including the Derbyshire streams which are swallowed up 
in it, the Trent, no doubt, could yield specimens of every fish known in English rivers. The Ouse I have chosen to describe as sober-minded and substantial. The Trent, so far as I have seen it, is a sparkling genius that makes its presence known by infinite brightness, dash, and impulse. The Ouse is a solid line of infantry, the Trent a glittering squadron of light cavalry. The scenery of the Trent is amongst the best to be found in the Midlands, while there are spots nowhere to be excelled this side of Severn or Tweed. Serving the busy Potteries in the outset of its course, it soon becomes aristocratic, and runs through Trentham, whose trees it lovingly laves, flowing with moderated pace through the beautiful park, and lending new charms to its far-famed gardens, terraces, temples, fountains, and hanging plantations. In the valley which the Trent gladdens are other great family seats-Meaford, Sandon, Ingestre, Tixall, Hagley, and Donington, where cliffs enter romantically into the composition of the landscape.

My most intimate angling acquaintance with the Trent is confined to a few miles below Nottingham, and unkind is the fate which prevents me at least once every summer from standing knee-deep for a day or two in the broad gravel bedded and rippling stream. It is Kirke White who applies to the river the term "rippling," and the term is photographic. The hapless lad loved to escape from the drudgery of the hosier's shop to the river's brink; and, if possible, afterwards, when more congenially engaged at Mr. Coldham's law office, where in busy times he attended from eight in the morning till eight in the evening, finding an hour still later for Latin study, thither tended his footsteps. In his seventeenth year-"scarcely the work of 
thirty minutes this morning" he told his brother Nevillehe wrote seven four-line verses of elegy on the death of a gentleman, drowned in the Trent while bathing, and says :-

" Of thee, as early I, with vagrant feet,

Hail the grey-sandal'd morn in Colwick's vale;

Of thee my sylvan reed shall warble sweet,

And wild-wood echoes shall repeat the tale."

When the dark days of disease and anxiety called upon the poet to recruit his overworked frame he went across to the little village of Wilford, near the Clifton woods, and it was in its churchyard that he applied to the Trent the designation I have repeated:-

" It is a lovely spot! The sultry Sun, From his meridian height, endeavours vainly To pierce the shadowy foliage, while the zephyr Comes wafting gently o'er the rippling Trent, And plays about my wan cheek. 'Tis a nook most pleasant."

The Trent anglers according to my observation are more sportsmanlike than their brethren of the Thames, and much more skilful as "all-round" anglers. Punts on the Trent are the exception instead of the rule; and the Nottingham anglers tell you that punt-fishing, pure and simple, is not Waltonianism of the highest kind. In the meadows close to Nottingham, even amongst the lads who find a livelihood in catching dace for bait, a frank, generous spirit exists amongst rivals, and there is no jealousy, grudging, or meanness. The Nottingham system, viz., the running line and travelling bait, is more artistic and telling than the tight line, and the Thames and Colne men, recognising this, are adopting it more and more. 
The Trent, notwithstanding the proverbial variety of its finny population, is chiefly interesting to the angler for its dace, barbel, and pike. Sport with them may be reckoned upon at times and in places where nothing else could be procured. Persons familiar with the river and its deeps find it worthy of all their attention as a haunt of pike. Here and there-and it is yearly becoming still more "here and there"-you may pick up a grayling. The Trent was once a noted grayling stream, and Hofland, one of the most reliable of angling authorities, a pleasant writer, and a prince of fly-fishers and fly-makers, thought well thirty years ago of the river in that character. A few grayling are still caught every season, but they are fast disappearing. Salmon, though not unknown in the Trent, are also few and far between.

As "to barbel, take the following quotation from a published paragraph : "Mr. B. and a friend captured over too pounds in one day near Colingham, and Mr. C. and a friend sent over So pounds on Wednesday night, with instructions to meet the trains every night, for they were hooking them every swim. Some were over nine pounds each."

I saw a pretty afternoon's sport one August day under the lee of a lonely wood below Lowdham. A groom and two friends in a boat, after a few swims finding no bites, went ashore for an hour and returned. The barbel at the previous trial were splashing like porpoises and turning over on the top of the water; now they were still as mice, and the three men at their first swim were fast to a fish each. So they went on catching great ruddy brown lively fellows which gave capital sport, and required every one of them careful playing and a strong landing net. The bottom of 
their boat was covered with spoil when the game was thrown up.

Old Nottingham, or, as I believe it should be called, Trent Bridge, ancient as the times of Edward the Elder, was a many-arched and picturesque structure, from which it was possible between the racing currents to catch barbel. There was a noted angler in the town whom, for convenience, we will designate Bowles, and he was quite historical as to barbel-a Gamaliel at whose feet stockingweaving Sauls sat to learn the wisdom pertaining to greaves, dew:worms, marsh-worms, brandlings, gilt-tails, red-worms, tegg-worms, peacock reds, dock grubs, and so forth: in which your Trent anglers, let me say, are remarkably learned. Bowles was an institution on Nottingham Bridge. Tradesmen and workfolks strolling that way in the cool of the evening naturally looked for Bowles, his spectacles, and his strong barbel rod. But he, I am informed, was never seen at his post after the following occurrence :-

The word was passed that Bowles had hooked a monster barbel. The news penetrated into the town, ascended to the workshops, ran along the meadows up and down, and caused great excitement. Looms, counters, tea-tables, business and pleasure were alike forsaken, and there was a regular stampede in the direction of Nottingham Bridge. Sure enough Bowles was engaged in a mighty struggle. The old man perspired, but never blenched.

The crowd became immense. Bowles would winch the monster in within a few yards of the shore, when, whew ! out it shot into the stream like an arrow from the bow. The superb skill and patience of Bowles were audibly commended; he was too wily to check the monster in those 
furious rushes, but waited till the line slackened to winch him cautiously and proudly in, amidst such cries as "Bravo, Bowles," or "He won't get over you, guv'nor," or "Give him time, Georgy."

The noise of the crowd hushed at last, for young Badger had, by direction, gone down to the water's edge to use the landing net. Bowles was bracing himself up for a final effort. Wind, wind, wind went the winch; in, in, in came the monster; "Be careful, Badger, be careful," said the crowd; "Now, then, nip him, nip him," shouted Bowles. Ah, me! what a tremendous roar there was when the monster was landed-a drowned retriever, with whose blown-out carcase the eddy had been playing unkind pranks !

Writing in 1839, Hofland, whose name one would ever mention with the tribute of admiration due to a master-hand and master spirit, also tells a story, though of a different kind, about Nottingham Bridge. At the risk of being abused for the unpardonable sin of garrulity I should like to repeat it, for the sake of pointing a moral to adorn his tale. Listen, then, to Hofland :-

"When I was a boy, and living at Nottingham, I frequently accompanied, to the River Trent, a gentleman who was fond of fishing for salmon from the bridge; he used to stand within the recess of a pier, and baited with two lobworms; he had a bullet on his line about twelve inches above the hook, with at least eighty yards of line upon his reel. He dropped his bait into the eddies, or pools, near the starlings; and in this manner he frequently caught large barbel, and sometimes a salmon. On one occasion, when I was only nine years old, I followed him to the bridge, and after I had patiently watched him for two or three hours, without seeing a fish caught, he gave the rod into my hands, showing me how to support it on the bridge, and telling me, if I felt a tug at the line, to let it run freely, and not to touch the reel, but to call out loudly, that either the toll- 
bar keeper or himself might come to my assistance. He then went to a public-house at a short distance from the turnpike house for refreshment, and had not been gone many minutes, when to my great surprise and delight, I felt two smart strokes at the line, which then ran out furiously, whilst I called out lustily, to the extent of my voice, and soon brought both my friend and the gatekeeper to my assistance. They were just in time to turn the fish before it had run out the extent of the line. A boat was procured, and assistance given on the water to the angler on the bridge, and, after nearly an hour's labour and anxiety, the fish was landed, and proved to be a salmon, in beautiful condition, weighing eighteen pounds and a half; so that I may say (in one sense) I caught a salmon at nine years of age, a circumstance which, undoubtedly, greatly fed my early passion for angling, and might have been a foundation for my becoming a great salmon-fisher, but circumstances have prevented me from having much practice in this noble branch of our art."

The moral to which I call the reader's attention is contained in the query-Where are those salmon? Let Messrs. Buckland and Walpole answer where, for is it not in their power to bring them back? Near Newark (where the best dace shallows are to be found, let me interject) I saw a salmon leaping last year; the year before I saw what everybody said was a salmon-and appearances favoured the supposition-rising repeatedly a few miles below Nottingham town.

Would you not consider sixteen dozen of dace, the lawful capture of the artificial fly, a pretty decent day's sport? I saw it with my own eyes done by a Notting ham angler, on a July day. It was at a part of the river where, broad though it is, you may wade across : and wade you must to do the best that can be done. This dace-master had occupied the same compartment of the train as I had, and had courteously, considering my strangerhood, offered to show me the best shallows and to place his fly-book at my disposal. He laid stress upon the latter because a special 
description of small hackle is required. His fishing boots, however, gave him an unapproachable advantage. Sixteen dozen dace and three or four pound roach lay in his rush basket when we met at night, all taken by a thinly-made red palmer with gold twist. Even I, the stranger, whipping from the bank, could show over four dozen silvery fish, running about three to the pound, exquisitely shaped, and more gamesome than the dace of either Thames or Colne. Anglers, perhaps I need not labour to show, do not always return from the Trent with sixteen dozen dace, but they would be downcast indeed if they did not surpass my four dozen, of which, nevertheless, I was very proud.

Of the higher waters of the Trent-and it may be assumed as a safe rule with all rivers which minister to large towns and ultimately become navigable, that they improve for the angler as you ascend them-Armstrong writes :-

" If the breathless chase, o'er hill and dale,

Exceed your strength, a sport of less fatigue,

Not less delightful, the prolific stream

Affords. The crystal rivulet, that o'er

A stormy channel rolls its rapid maze,

Swarms with the silver fry. Such, through the bounds

Of pastoral Stafford, runs the brawling Trent."

A chapter upon Midland Streams would be incomplete without a word upon those classic tributaries of the Trent, the Dove and the Derwent, and the sub-tributary the Wye. And a word only may suffice for rivers immortalised by Walton and Cotton, and by the numerous disciples who have spoken or sung their beauties until this day. Time has, unfortunately, considerably reduced the trout and grayling as to numbers, but the angler may still reap honour in the well-known dales of Derbyshire. The straits of Dovedale, 
romantic Ashbourn, Cotton's fishing house, and the steeple shaped rock in Pike Pool-could we not sketch each from memory, so familiar are we with the written and pictorial descriptions of them? Of the modern angling I will say no further than that the bungler will not deprive Dove, Derwent, or Wye of its wary denizens. It is difficult to rise them at any time, and, that accomplished, the battle has to be won with the tiniest hook and finest of gut lines.

Once these waters were free, but there is little left now unpreserved. Some portions, however, may be reached through the consent of local fishing clubs, and at Rowsley and Bakewell, where both Derwent and Wye are within short distances, the hotel landlords are allowed by the Duke of Devonshire to grant tickets to customers. There are plenty of flymakers in all the Derbyshire fishing villages, and it is impossible to improve upon the neat little hackles which they provide according to the sky, water, and season.

Practical Notes upon Bream, Bareel, and Chue Fishing.

In the preceding chapters I have pointed out the fishing which may be had in April, May, and June, and the present notes are intended to apply to July, and to the coarse fish, which, often taken in June, are more generally looked for in their heyday - namely, July and August.

Bream are sometimes taken in the Thames and Lea, but they prefer stiller waters, and there is no better bream river in the country than the Ouse. The wholesale nature of the sport when it does come often tempts anglers in the cool môrnings and evenings of our hottest month to forget or 
stifle their dislike to the fish and the "messy" nature of the mode of capture. Being very shy fellows, although you may kill a hundredweight of them, there is some skill required.

There is not much to add to what has been said of the bream in the foregoing chapter. Always, however, fish for bream on the ground, and keep out of sight. Be slow to strike, for the bream, like the tench, loves to suck the bait, to rise with it until the float is flat on the water, and yet to keep clear of the hook. A large bait being preferred, and the mouth being narrow and small, ample time, in reason, should be given. The largest bream I have seen were three specimens caught by a gentleman up the Lea, and exhibited in the office window of the Field. They were handsome and beautifully stuffed fish, and each had weighed an ounce or so more or less than seven pounds. Walton understood bream-fishing well, and is right in his observation: "After three or four days' fishing together your game will be very shy and wary, and you shall hardly get above a bite or two at a baiting: then your only way is to desist from your sport." Ephemera mentions that he has frequently caught bream with the artificial fly-brown palmers, the governor, and yellow and white moths.

Barbel-fishing is carried to a pitch of excellence both in the Thames and Trent, and in both it is no uncommon thing to slay over fifty pounds weight at a sitting. Ground baiting with chopped lobworms is the necessary preliminary, and Nottingham is the great lobworm emporium, from which the Thames men in their most sanguinary campaigns order them by telegraph. The barbel has an unconquerable spirit and a strong body of his own, and though he, like his 
relative the bream, need never be thought of as a common article of food, he is a foeman worthy of your (Limerick) steel. Ten, twelve, and fourteen pound fish have been taken from both Thames and Trent, and the barbel has this point in his favour-once fairly hooked, his leather mouth will not give way, so that the angler may cope with him in the confident hope that with patience and care the prize is his. As the fish loves swift deep streams, and the company of his fellows, barbel angling at successful times is a merry business both as to quantity and quality.

The chub is on a par with the other coarse fish for eating purposes, but he is entitled to respect as a greedy fly-taker and a timid member of the brotherhood of fish. "What shall be done with my chub or cheven that I have caught?" asks Venator. "Marry, sir, it shall be given away to some poor body," replies Piscator. You cannot do wrong by following that example. If it were my fate to catch a basket. ful of chub, bream, or barbel, every day, I know how to dispose of them so as to make the eyes of many little folks glisten at the prospect of an unwonted meal. Hunger, strong condiments, and not too high a standard of taste make them acceptable and palatable. Chub will take a variety of baits. I have known him caught with a live minnow, a dead gudgeon, worms, gentles, pastes, greaves, bullock's pith, fat bacon, and pounded cheese. But for his readiness to take the fly I should almost write the chavender a winter fish. The chub is much disconcerted at the hooking of a comrade; the shoal will pursue an "unfortunate member to your very landing net, and take remarkably good care not to imitate his conduct for some time to come. In the Loddon there are enormous chub, and I know of an instance in that 
river of a Leviathan following a hooked juvenile to the bank, and by a direct blow delivering him from the spoiler. This might have been an accident, but the movements of the chivalrous cheven rendered it impossible to doubt that it was an accident purposely committed. There are some chub in the Lea, and the Lea men are fond of taking them with a blow line, and live grasshoppers or "daddylong-legs." The Trent, Ouse, Thames, and indeed all our large rivers, contain chub. By a riverside it is necessary to keep your shadow from the water. The chub requires as much stalking as a Highland decr. Nothing is lost by kneeling down on the grass above or below a chub hole or shallow where you know chub are swimming, and waiting five minutes in solemn stillness until you begin operations, and if you can contrive to pitch your artificial bee, palmer, or moth upon the brink's herbage and let it drop quite casually into the river so much the better. 


\section{CHAPTER VI.}

\section{WHARFEDALE.}

"A day without too bright a beam,

A warm, but not a scorching sun ;

A southern gale to curl the stream,

And, master, half our work is done."

FEw rambles with his rod will afford the angler more pleasure, none will be with better welcome recalled during those musings when, lounging in the winter-time by the ruddy fire in a stormy twilight, he turns over page after,page of that wonderful and never-failing photographic album which is stored with the plates of memory, than his visit to Wharfedale. It is an autumn's amusement that will well bear the winter's reflection.

The Southrons of this kingdom are guilty of a heavy crime; they do not know as much about Yorkshire as they ought to do. Most people I have noticed-except perhaps the Germans-exercise the right of remaining remarkably ignorant of their own country: and it must be confessed with shamefacedness that we English are not a whit behind other nations in general ignorance of the beauties of our own fatherland. Yorkshire especially suffers from this singular neglect. You meet with men and women who are aware that the St. Leger is run at Doncaster, and maybe that Doncaster is in Yorkshire; that there are springs of nasty, though perhaps wholesome, mineral water at Harrogate, 
and that Scarborough is a fashionable and late wateringplace. They may possibly, too, remember being taught at school that Yorkshire is the largest county in England; they may be in a position to assure you that it produces a popular pudding which mates worthily with the Roast Beef of Old England; they have vague ideas that it is famous for " tykes."

Yet Yorkshire has been gifted with natural advantages and charms which are unrivalled. I have set to myself in this chapter the task of gossiping chiefly about the grayling as you find him in the romantic Wharfe, else I could fill many a page with attempted glurifications of the sweet wooded dales, the lofty fells, the far-stretching wolds, the rolling moors, the rare historical associations, and the bounteous mineral and agricultural features of the rich county which covers 5,983 square miles of territory as important as any to the welfare of the State :-

"The lofty woods; the forests wide and long,

Adorned with leaves and branches fresh and green,

In whose cool bow'rs the birds with chanting song

Do welcome with their quire the summer's queen.

The meadows fair, where Flora's gifts among

Are intel mix'd, the verdant grass between;

The silver scaled fish that softly swim

Within the brooks and crystal wat'ry brim."

In justice to my readers I feel moved to admit the possibility of looking upon Wharfedale with eyes that refused to behold defects, of hurrying to its woods and streams in a frame of mind under which I should have magnified into picturesqueness the most ordinary landscape. In a word, I had been attending the annual meeting of the British Association. I had drenched myself with science: had 
perseveringly sat out the sectional gatherings; had courageously endeavoured to follow dissertations on dirt, dust, and brickbats ; had pretended to be interested in discussions on shoddy, in the homologues of oxalic acid, thermal conductivity, protoplasm, the electrical phenomena which accompany the contraction of the cup of Venus's fly-trap, hyperelliptic functions, and serpent worship in the pre-historic era.

These are serious subjects, and far be it from me to scoff at the learned papers read to explain them. On the contrary I owe them a special vote of thanks, which I hereby propose, second, and carry nem. con., for the excellent preparation they proved for the moment of release. Bradford was eminently hospitable and pleasant during that British Association visit, but there was one member, I can honestly vouch, who joyfully rushed to the ticket office and booked "straight away," as the railway porters have it, to Otley, and who, putting away the spectacles and solemn demeanour that became a savant of the nineteenth century, lit his meerschaum and began to overhaul his fly-book the moment the train started.

The Wharfe illustrates the old saying "Variety is charming," for it is a decided mixture of gentleness and anger. You would scarcely fancy, standing on the handsome bridge spanning it at Tadcaster, that the docile river which here begins to be navigable is so obstreperous in the upper part of the dale. The scenery of Lower Wharfedale is not so striking as that which delights you as you push upwards, but the grayling fishing is infinitely superior. Strolling down stream on the right bank at Boston Spa, for example, there is some open water that should be tried in passing. 
It would be convenient perhaps to make known to all whom it may concern that some of the best portions of the Wharfe are strictly preserved, and that the angler generally should fish rather down than up the stream. Bearing this in mind, let us proceed towards Wetherby; at a-place called Flint Mills there is a splendid piece of grayling water, but it is difficult to obtain the requisite permission to bring it under contribution. Wetherby may be passed by lightly, but not Collingham. Even now the angling there is good, but it has, in common with that of every fishing station in the country, greatly deteriorated during the last few years. Above Harewood, if you are fortunate enough to possess the "Open Sesame" to the preserves at Arthington, you may capture plenty of grayling and a few trout. About twenty years ago an angling club at Harewood rented one side of the stream, and then the grayling fishing of the Wharfe was in its prime. I recently conversed with a middle-aged gentleman who was born in the district, and he assured me he once saw a basket of seventy-five grayling taken with the fly in one day by one rod between Collingham and Woodhall-a piece of luck, I need scarcely add, never to be approached in these later days.

At Otley, for some cause not very explainable, grayling are not so numerous as trout; but whether your purpose in visiting Wharfedale be rambling or angling, or both (which is far better), Otley will be found a convenient startingpoint, or even head centre. Here I had proposed making a somewhat protracted halt, knowing that sport would diminish in proportion as the scenery of Upper Wharfedale increased in variety and beauty. Besides, Otley is in itself a pretty place $-\mathrm{a}$ sweet refuge for the weary. If 
it be any gratification to know that long before the Conquest the manor hereabouts was given to the Archbishops of York, open that red-covered book on the coffeeroom table, and you will see the details in black and white.

I remember reading somewhere in $\overline{\text { a }}$ treatise on grayling that the fish was introduced into the country by monks when England was undisguisedly-to coin a word, and of course without offence to any creature-a monkery, and that the good St. Ambrose was particularly fond of the grayling. The saint in that case knew what was good for himself. This thought occurred to me on glancing at the guide-book literature of the coffee-room, and I then further remembered how the saints and abbots and holy friars invariably pitched their abodes near a river of great fishproducing capabilities, and how they often supplemented the stream with ponds and stews for the more ready and certain supply of their larders. It is generally conceded that the grayling, not being indigenous to English streams, must have been imported from the Continent, probably from Germany, and the monks might as reasonably be credited with the importation as any other class of men.

I should have remained longer at Otley had I not on the very first day encountered a hair of the dog that had bitten me at Bradford. A learned Dryasdust, full of archæology, having remembered my face at the sections, fancied my pleasure would be consulted by giving me relief "in kind," wherefore the worthy gentleman forthwith pursued me relentlessly with his facts and fancies, which were, truth to tell, a pretty equally mixed assortment. He told me that 
Athelstan had had dealings with Otley, and I asked him if he knew whether that eminent Saxon king tied his own flies. The philosopher at first, I fear, suspected me of trying to get a rise out of him, but after a pause meekly informed me that he had perused most of the ancient documents concerning that part of the Riding, but had observed nothing that would throw a light upon that subject. I am not sure to this moment whether the patient antiquarian said this in humble innocence or as a covert rebuke.

A short distance out of the town stands a cliff called the Chevin, and this, as readers of old-fashioned angling books know, with a trifling difference in the spelling, is also the name of a certain fish.

"The Chevin," said the rev. gentleman, "used to present"

"Ah! talking of chub," I remarked, "do you ever find any in the Wharfe?"

Then the archæologist-who, by the way, was not the genial informant whom we are always glad to meet and grateful to hear, but somewhat of a bore given to conceit-gave up the angler as a bad investment, and shuffled behind him. It did so unfortunately happen that just then the latter was on the point of casting his flies upon the stream, and somehow or other the archæologist managed to receive the dropper in the rim of his wideawake; indeed, it might as well be confessed that another inch and the evening's sport would have included an archæologist's ear. The worthy man, however, insisted upon accompanying me, saw me to my chamber door at night, and was waiting at the bottom of the stairs on my appearance in the morning. The grayling of Otley were no doubt 
gainers by this intrusive companionship, inasmuch as the persecuted angler who was in search of-

"Respite—-respite, and nepenthe"

from the parliament of science, lost no time in reckoning with his host and departing from the "field of Otho."

The railway has accomplished many wonders and over. come many difficulties. Steadily and surely it has intruded into the realms of romance and reduced them to its own utilitarian level. But Upper Wharfedale hitherto has defied it. Nor is it easy to perceive how it is possible to lay down a permanent way over Barden and Conistone Moors, or to convert Bolton Abbey into a station and Great Whernside into a terminus. It fills me, I confess, with a savage glee to spread out the map and behold how the iron horse has snorted and screamed up to the very foot of the balmy moorlands, and then stopped short, sullen and defeated. Thrice did he start off to invade the district of which Skipten may be taken as the southern, Ripon the eastern, the Westmoreland border the western, and Barnard Castle the northern limits. At Ilkley he was frightened by Rombald's Moor and the uplands towards Bolton. At Pateley Bridge, Dallowgill and Appletrewick Moors blocked the way; and at Leyburn a judicious halt was sounded, at least for the present.

None but strong, enduring pedestrians can, therefore, do Wharfedale full justice, and it may be here said generally that every turn of the stream from Otley to its source under the brow of Cam Fell will repay the pedestrian, and reveal new surprises in itself, in the vistas beyond, and in the ever-varying quantities and qualities of its steep wooded banks. 
Ilkley and Ben Rhydding receive much of their popularity from the scenery of the Wharfe, and the former watering-place, so well known to hydropathists, owes its repute as much to the little impetuous stream galloping over the breezy side of Rombalds, as to the bracing mountain air. But we cannot afford to linger here, with Bolton Abbey beckoning us onward. Bolton Bridge, reached from llkley by a delightful five miles of road, overlooking the Wharfe on the right and skirting umbrageous woods on the left, will serve admirably as the wanderer's temporary head-quarters. The hamlet itself offers nothing extraordinary either in landscape, architecture, or commerce, but the view above and below from the bridge charmingly combines the pastoral and romantic in harmonious proportions.

Having procured his ticket, easily obtainable at the inns, and turned into the meadow on the left bank of the river, it would save time if the angler did not put his rod together until he had arrived at the plantation adjoining the grounds of Bolton Abbey. Indeed he would be wise, if a stranger to the far-famed ruins, to inspect them before going down to the river, and possess himself of the legends and architectural features of the place. Both are fascinating. Let us sit down upon this meadow grass and hear the legend-in-chief.

First look abroad. For a little space in front and across the stream you have a park-like prospect, lawn and trees appearing at intervals. Towards the priory, however, the noble woods close in high and thick, making us curious to see how the Wharfe, "the swift Werfe" of the poet Spenser, threads its way through the devious overhung course. In many places yonder the foliage touches the water. The 
earlier tints of auturn are already stealing over the leaves, for the sportsmen have for three weeks been amongst the stubble and turnips, and we can hear the frequent crack of their fowling-pieces away in the fields. The autumn tints are at their prime, and you shall not be able to deny that Wharfedale hereabouts is one of the most entrancing of sights for those who love the garment of many colours with which the declining year adorns itself : for this reason, and also perhaps because the grayling is in good condition in October, it is the resort of visitors when other places are deserted.

A fine herd of Herefords, most effective of all cattle as component parts of a landscape, contentedly muse under the trees or crop the succulent herbage. The smoke rises above yonder orchard blue and straight, sure sign that the harvest is passed and summer ended, and that the atmosphere is flavoured with frost. A healthy-faced Yorkshire boy swings on the gate, which his sisters-as little sisters, bless them ! always cheerfully do-laughingly set in motion. The stream is here shallow and wide, but the bouldery bed has been, and anon will be again, washed by a furious torrent, the scouring of moor and fell for many a mile. It is a peculiarity of much of the Wharfe that while on one side the river's bed shelves very gently to the centre, on the other it runs deep under a steep and generally curving shore. Higher up the stream the woods lift up their richly plumed heads far towards the sky, and you know that close at hand, concealed behind the superabundant foliage, is the remnant of what was once Bolton Abbey. This is why I suggest you should lay aside your rod and rest a space here, postponing acquaintance with the grayling in favour of traditionary lore. 
What say you, then? And now for the legend of Bolton Priory.

Perhaps on second thoughts it will interest us more if we stroll towards it and talk as we go. The field we are now crossing, and whose fine soft grass rebounds beneath our footfall as if it were the turf of a well-kept lawn, was selected, they say, for camping ground by Prince Rupert on his way to Marston Moor, and if that impulsive freebooter acted upon his customary principles he looted yonder farmyards to a pretty good tune. The old priory stands in the centre of a picture which has been faithfully filled in by Whitaker in his "History of Craven":- "But after all the glories of Bolton are on the north. Whaterer the most fastidious taste could require to constitute a perfect landscape is not only found here but in its proper place. In front and immediately under the eyes is a smooth expanse of park-like enclosure, spotted with native elm, ash, etc., of the finest growth."

(The "etc.", you will note, includes some patriarchal beeches, oaks, aspens, poplars, and, half up the opposite slope, there are mountain ashes that in the late autumn ever gleam a ripe crimson blaze on the hillside.)

"On the right, a skirting oak wood with jutting points of grey rock; on the left, a rising copse. Still forward are seen the aged groves of Bolton Park, the growth of centuries; and farther yet the barren and rocky distances of Simon's Seat and Barden Fell, contrasted to the warmth, fertility, and luxuriant foliage of the valley below."

Pursuing our way upwards, the woods on either side hem us in; tinkling brooks and fairy-like glens appear; the Wharfe, having assumed every shape of which a river is 
capable, henceforth consistently retains the characteristics of a mountain stream. Immediately above the priory its bed is full of large boulders ; beyond, it runs still and deep; here it narrows and there it widens--everywhere it has the bright bubbling charm of variety. This is what we have for two miles, and then we reach the Strid. At this spotthe Mecca of the Wharfedale tourist-the river gallops through a deep sluice between two rocks, so narrow that you may leap across it. Hence its name. And here it is the legend must be told; after which let the grayling look out.

A certain fishiness about the story makes it quite appropriate at this time and place. One Lady Alice had a son who came to an untimely end in this madly-hurrying current which, as we sit over it, roars in our ears. The story has been best told by Rogers, who shall, with the reader's permission, tell it again for our benefit. Wordsworth's version, though substantially the same, is, compared with Rogers's, even "as water unto wine." Says Rogers :-

"At Embasy rung the matin bell, The stag was roused on Barden Fell;

The mingled sounds were swelling, dying,

And down the Wharfe a hern was flying;

When, near the cabin in the wood,

In tartan clad and forest green,

With hound in leash and hawk in hood,

The boy of Egremond was seen.

Blithe was his song - a song of yore ;

But where the rock is rent in two,

And the river rushes through,

His voice was heard no more.

- 'Twas but a step, the gulf he passed;

But that step-it was his last!

As through the mist he winged his way 
(A cloud that hovers night and day),

The hound hung back, and back he drew

The master and his merlin too!

That narrow place of noise and strife

Received their little all of life."

So far all authorities are agreed, but an inspection of certain musty documents throws some doubt upon the sequel. The Lady Alice, according to Wordsworth's acceptation of the popular legend, was apprised of the lad's fate by a forester, who, with a tact and delicacy not unusual, pray observe, even in those rude times, prepared the poor lady for his intelligence by asking-

"What remains when prayer is unavailing?"

Quoth the bereaved mother, "Endless sorrow."

"From which affliction-when the grace Of God had in her heart found place-

A pious structure fair to see,

Rose up, this stately priory."

That is Mr. Wordsworth; but the version which seems, not only from documentary evidence, but from our knowledge of the parties interested, to be most likely is that the abbots and monks of Embasy, up in the bleak fell district, tired of their lonely situation (and there being no fish handy), took advantage of the lady's grief to descend into the valley and remove their priory nearer the beeves and trout. Anyhow the priory was wealthily endowed, and in a short space of time the monks-self-denying souls!-possessed 2,I93 sheep, 713 horned cattle, 95 pigs, and 9I goats.

The man sauntering towards us is the water keeper, and he will recommend us to retrace our steps. He tells us he has been trying all the morning to catch a dish of grayling 
for the Hall, but without success. Strapped to his back, in lieu of the orthodox creel, he carries a wooden box fashioned as closely as possible to imitate a fishing basket. He made it himself, and his rod and line were also the work of his own hands. They are heavy and rough, it is true, but in his grasp they can be made to do all that is necessary. He purposely uses a large heavy line, with which alone, he says, you can fish thoroughly against wind. It is astonishing to see how lightly, easily, accurately, and to what distance he casts his flies with that clumsy sixteen feet rod painted green, and that heavy horsehair line.

His casting lines are of a kind peculiar to the Wharfe, I believe. He uses nothing but horsehair, beginning with four or five strands and gradually lessening the bulk until the last eighteen inches of the four yards are single hair. He never fishes with less than five flies, tied by himself.

"He shakes the boughs that on the margin grow, Which o'er the stream a waving forest throw, When if an insect fall (his certain guide), He gently takes him from the whirling tide, Examines well his form with curious eyes, His gaudy vest, his wings, his horns, his size; Then round the hook the chosen fur he winds, And on the back a speckled feather binds; So just the colours shine through every part, That nature seems to live again in art."

There is a grey pony in the neighbourhood, I am told, whose long tail has been quite a small fortune to its owner during the last fifteen years, and a local wag says the grayling give over rising the moment the animal which has contributed so long to their family death-roll comes down to the margin to drink. The keeper is not prepared to 
sign an affidavit in verification of this assertion, but he certainly has in his greasy pocket-book a large collection of long grey horsehairs, and furs and feathers innumerable.

Do not be too haughty to believe that a few expeditions with a man like this are worth any quantity of mere theory, and that it is always best to follow his advice when once you are convinced that he is to be trusted. That is a principle I have never found to fail. You may be learned in piscatorial lore, may be an old stager at the waterside, may be in all ways an adept admitted and proved; but a practised native, though he reads not neither can he write, will be your master on his own ground.

Thus, though my book contained the most approved flies used in Herefordshire, Derbyshire, and Hampshire (all first-class grayling counties), I without hesitation took the keeper's tiny, artistic hack!es, and in the course of a few days proved by practical experience the infinite superiority of his knowledge and wisdom. I fancy the best Wharfe fly-makers live at Otley. Their brown owl is a killing fly; so is the little hackle termed a fog black. Partridge and woodcock hackles and a black gnat are favourites, and you never see a native's cast that does not possess a pretty hackle made of the under wing of the snipe with body of straw-coloured silk.

"Fish in the eye of a stream, sir," our keeper advises; and he shows us how to do it, by dropping his flies like snow flakes across where the water scrambles over the stones previous to a drop and sweep into deeper volume.

"Grayling are like women, sir-you never know what to be about with them," he sagely remarked. By this our Yorkshire guide showed that he had studied well the 
character, not perhaps of the sex, but of the fish. They are undoubtedly skittish cattle (fish, and once more, not women), as we were that day and the next destined to find. One could almost fancy that they were cognisant of their rarity and value, and gave themselves airs in consequence. Cotton, who ought to be a good authority on the matter, seeing that the Derbyshire streams where he exercised his skill were, and in a minor degree still are, famous for their grayling, has no high opinion of the fish. His pupil exclaims-

"I have him now, but he is gone down towards the bottom. I cannot see what he is ; yet he should be a good fish by his weight ; but he makes no stir."

"Why, then," the master replies, "by what you say, I dare venture to assure you it is a grayling, who is one of the deadest-hearted fishes in the world, and the bigger he is the more easily taken. Look you, now you see him plain; I told you what he was. Bring hither that landing-net, boy! And now, sir, he is your own, and believe me, a good one, sixteen inches long I warrant him."

If the grayling thus described had brought an action for libel against Charles Cotton, of Beresford Hall, in the county of Derby, Esquire, a fair-minded jury must have found a verdict with damages. The grayling is in every sense by which a fish may be judged entitled to respect. Walton, who was as innocently credulous as a child in matters with which he was not practically acquainted, who would believe almost any story so long as it appealed to his quaint simple sentiment, and who probably knew less about the grayling than any other English fish, is inclined to place him on a pinnacle of honour. He reminds us that Gesner 
terms it the choicest of all fish; that the French, who vilify the chub, term the grayling (or umber) un umble chevalier. Without exactly endorsing the statement, Walton retails with some unction the Frenchman's dictum that the grayling feeds on gold, and informs his readers that St. Ambrose, "the glorious Bishop of Milan," calls him the flower of fishes, and was so far in love with him that he would not let him pass without the honour of a long discourse.

Now the grayling, though not gorgeously marked, like the trout, is, to my thinking, of more gracefully proportioned shape, and not: by any means the chicken-hearted brute described by Cotton. Like the trout, the grayling takes much of his character from the stream he inhabits, and we found the Wharfe grayling, though not large, were of the most perfect symmetry, colour, and flavour. When the grayling first leaves the water, nothing can be more beautiful than the almost impalpable vestment of royal purple which shines over his silver undermail, and the long distinct thin line running along the middle of his side, from his bright lozenge-shaped eye to his purple tail. His tapered snout and round, elegantly proportioned body, his white belly, with a suspicion of gold along each side, the small square dark spots about his sides, and the marking of his fins, increase the beauty of this high-bred looking fish.

There is a dispute as to the smell of the grayling in the first few moments of his capture, some arguing in favour of thyme, and some saying the perfume is that of the cucumber. The fish has been designated salmo thymallus in honour of 'the thyme theory. Opinions upon this knotty point $\mathrm{I}$ think will always differ. A fish taken from the Terne I once thought had a decided smell of cucumber, another from the 
Itchen was redolent of thyme; the first which the Wharfe yielded at the visit which is the subject of our present thought smelled of something which the keeper said was cucumber, while I equally maintained it was thyme. Very likely if we had never heard or read of the alleged odours the fancj would not have occurred to us!

Our Wharfedale experiences were those of every grayling fisher who uses the fly. We were certain of nothing. Roving and sinking as the anglers practise it in Herefordshire with grasshopper or gentle is probably the most certain way of catching the grayling, who loves to lie close to the ground, grubbing upon the sand or gravel, which he prefers to any other bed. Even when he takes the fly, which he will do at all times, not excepting the winter frosts, if the sun should peep out for an hour or two in the middle of the day, he rises swift and straight from the deepest parts of the river, and descends again with equal speed. His movements are indeed so rapid that the hesitation of an instant on your part will be fatal. The fish loves either the eye or tail of a current; upon being hooked he rushes for the stream, and as in most cases your hook must be of the smallest, and the grayling's mouth is remarkably tender, your proportion of lost fish will be greater with grayling than with trout.

"It is no good, sir," the keeper said, after we had both carefully fished a mile of the Wharfe and missed every fish that rose, each of which had been faintly pricked; "they are at their old tricks. I've touched a dozen fish to-day and caught none, and sometimes they go on like this all day long. We shall get them between three and five this afternoon, but not before."

$\mathrm{He}$ acted upon his own opinion and ceased angling, 
preferring to husband his strength for subsequent efforts, and watch me fish the rapids for trout. It turned out in the afternoon as it had been predicted. The grayling rose moderately, but whereas in the morning we both missed everything, we now landed all that we touched-eight beautiful fish of about three-quarters of a pound each. When the sun began to touch shadow-land, and the autumnal coolness of evening to succeed, the grayling rose no more. This is their habit, and their habit requires most careful study both as regards general characteristics and the peculiarities of locality. No fish requires such careful watching as the grayling, and when I hear him condemned or spoken lightly of I suspect that the fault lies with the blamer rather than the blamed. So long as I remained in Wharfedale and in the keeper's neighbourhood, he would in the morning, as a first and prime duty, look round at the sky, and then at the water, and at the insects moving about, and pronounce an opinion as to the probabilities of sport; and his general accuracy was surprising.

At Bolton the fish are not numerous : two or three brace constituted a day's average sport; ibut I met some fishermen who had for a fortnight been unable to take a single grayling, although they had caught a few small trout. Anglers differ greatly in their estimate of a grayling's weight. One Wharfedale fisher, when I told him I had seen a Hampshire fish that scaled over three pounds and a half, coughed incredulously, and said-

"Ah, that was a big one indeed."

Plainly he did not believe me. It is rarely grayling so large as this are seen, and the monster $I$ quote was a supremely ugly fellow. A pound fish is a good one, and 
though he will not fight so desperately as a trout, he does not die without a plucky struggle. Prop erly hooked, however, a grayling ought never to be lost; but let the unsuccessful grayling angler be consoled with the reflection that many otherwise excellent fly-fishers have never mastered the art of thoroughly hooking this fish. The sun, except on frosty mornings, is bad for grayling fishing-fog, frost, wind, rain, anything but sun may be tolerated, and unlike most descriptions of fish the grayling is not to be met with early in the morning or late in the evening.

My Wharfedale expedition, though not, I confess, productive of much in the way of pisci-slaughter, was never regretted; there was too much to admire, too much to be interested about, and then as to fish, one can always console one's self with the anciently expressed comfort-

"If the all-ruling Power please

We live to see another May, We'li recompense an age of these

Foul days in one fine fishing day."

\section{Practical Notes on Grayling Rivers.}

It is possible the recent attempt to introduce grayling into the Thames may be more successful than the efforts with salmon and trout, and the gentlemen who are deserving the thanks of all anglers for their perseverance may find some encouragement in what Sir Humphrey Davy, who studied the grayling with intelligence if not indisputable science, lays down as to the habits and nature of the fish. His leading conditions are certainly fulfilled in the Thames. Summarised, the conditions under which he says the grayling will breed and thrive are- $a$ moderate temperature of water, a 
combination of stream and pool, shallows of marl, loam, and gravel, and an abundance of flies and larvæ. The grayling grows with marvellous rapidity, moves from one part of the river to another in a migratory mood, and can exist-as it does in the Tyrol-in a turbid stream. The fish has been introduced with success into the upper portions of the Clyde watershed, and in other Scotch rivers to which they were aitogether foreign. At the same time it must not be forgotten that a former attempt to introduce the grayling into the Thames failed. The Lug seems by general consent to be considered the best of modern grayling rivers. Rising in Radnorshire it flows for about thirty miles through the most fertile tracts of fruitful Herefordshire, and joins the Wye at Mordiford. For several miles after entering the Fnglish county the river course abounds in fine valley scenery. Leominster, the town famous for its five W's, "water, wool, wheat, wood, and women," is the town which best commands the Lug-the key of the position, so to speak.

Many grayling-masters give the preference, nevertheless, to the Teme, and no doubt in Sir Humphrey Davy's time it was far superior to any other river. It is swift running, and along its downward course of sixty miles-it falls 367 feet from its junction with the Onny, near Ludlow-it presents an unusual number of rapids, rocky ledges, and deep pools. It first waters a bit of Wales, and then fertilises the counties. of Shropshire, Hereford, and Worcester, where the capacious Severn receives it. Ludlow is to the Teme what Leominster is to the Lug, and they both enjoy the rarest advantages of situation, the one in a luxuriant vale, the other on an eminence crowned with the grey ruins of a picturesque castle. The Derbyshire streams have been referred to in the. 
previous chapter ; they are most probably our very earliest grayling waters.

Hampshire possesses good grayling streams, and Hampshire men, if they acknowledge that the Hereford rivers are superior as to quantity, nevertheless stoutly insist that their Test can show the biggest fish. Occasional fish are to be found in the Avon and Itchen. The Test is a famous trout river, and has been so from time immemorial, but grayling were brought to it only within the last century. It is a noted angling river at Whitchurch, Stockbridge, and Romsey, and carefully preserved by landowners or local associations. It is a remarkably placid-flowing stream, and on this account, and because of its clearness, there is demanded the highest exercise of skill on the part of the angler. It is turned to excellent account by the millers and farmers along its level and pastoral course, and receives many small tributaries before, at Redbridge, it forms the higher branch of Southampton water. The Houghton and Leckford fishing clubs on the Test are historical to anglers. Dr. Wollaston, Sir Francis Chantrey, and R. Brinsley Sheridan were members, and Sheridan drew up a set of very funny rules and regulations for the guidance of the angling party of which he was a member. These laws in Sheridan's own handwriting were years gone by presented to the old Walton and Cotton Club, and I hope the reader will grant me pardon if I transcribe a few of the most humorous sentences :-

"That each male member of the party shall forthwith subscribe the sum of five pounds five shillings towards the general expenses, and that such subscriber do realiy pay the same into the hands of the treasurer.

"Henry Scott, Esq., Captain of the Light Infantry of 
South Hants, to be collector of the said subscriptions in the town department. The said captain having given a great proof of ability for that office, inasmuch as he has already collected five guineas from Gigar, alias Mathew Lee, Esq., and the society have the strongest hopes that he will give an equally unexpected proof of his integrity by paying over the said sum into the hands of the treasurer.

"A journal is to be kept of the occurrences of each day, which, among other interesting matters, is to contain an account of the number of fish caught, their respective weights, by whom caught, \&c., \&c.

"The said journal is at a proper time to be printed and published, and although the party are confident that the said journal will also be a record of wit, humour, pleasantry, and possibly even of deep observation, from the acknowledged and various talents of the said party, yet, disdaining all personal advantage, it is resolved, in humble imitation of the example set by the Rev. J. W. L. Bowles, that in case any copies of the said fresh-water log-book should be sold the profits shall be solely applied to the benefit of the widows and orphans of deceased fishermen.

"No drawing, painting, sketch, or model of any trout shall be taken at the general expense, unless such fish shall have exceeded the weight of five pounds, and shall have been bona fide caught by one of the party, and not privately bought at Stockbridge.

"Any member describing the strength, size, weight of any immense fish which he had skilfully hooked, dexterously played with, and successfuliy brought to the bank, when by the clumsiness of the man with the landing netonly conceive how provoking-the said fish got off, shall 
forfeit half-a-guinea and, so toties quoties for every such narrative. To prevent unnecessary trouble, the said forfeits are to be collected by the Rev. J. O.

"There shall be but one hot meal in the course of the day, and that shall be a supper at nine o'clock; cold meat and other refreshments in the tents or at the waterside at two o'clock.

"A committee is to be appointed"to provide these repasts, and shall be called and entitled the Catering Committee, and their decision as to snack and supper shall be final.

"Any member willing to send in any stores for the general benefit at his own expense shall be permitted so to do, and is entitled to be laughed at accordingly.

"All fish by whomsoever caught are to be considered as general property, and if there are sufficient to send any as presents the choice of the fish shall be determined by lot; always excepting such as shall be sent to the drawingroom, which are to be a tribute from the firms.

"Any gentleman falsely, shabbily, and treacherously concealing the number of fish he had caught, and slily sending off any of the same as a present to ladies or others, shall forfeit on detection one guinea for each fish so purloined from the common stock, and be publicly reprimanded at supper for the same. Mrs. Sheridan is not to draw up the form of reprimand.

"Any person restless and fidgety, presuming to insinuate that sea-fishing is preferable to the tame and tranquil occupation of this party, and detected in endeavouring to inveigle elsewhere any of the liege and dutiful subjects of Izaak Walton, shall on conviction be sentenced to fourteen minutes' abstinence from ale, beer, porter, wine, brandy, 
rum, gin, hollands, grog, shrub, punch, toddy, swiperus, caulkers, pipe, segar, quid, shag, pigtail, short-cut, varines, canaster, pickater, and if such culprit shall appeal against the severity of the above sentence as a punishment disproportioned to the utmost excess of human delinquency, he shall be entitled to have rehearing, and Nat Ogle assigned to him as counsel.

"The Rev. — - is not to chew the tobacco called pigtail after sunset, as he will then join the society of ladies; nor for the same reason is Jos. Richardson, Esq., M.P., and author of the 'Fugitives,' to flick his snuff about during supper, even though he should have been competing with Nat Ogle."

The Itchen is a carefully preserved trout river, but, as before hinted, less plentiful in grayling, and even then chiefly in its lower parts. There is good sport with the trout when the Mayfly is on, and Hammond, of Winchester, is the authority from whom to seei information. There is a little open water left, but I have seen very fair success in the heart of Winchester city by townsmen who. knew where to find their fish. Below Winchester good fishing may be obtained by the purchase from Mr. Hammond of day, weekly, or monthly tickets.

About Alresford the trout are large and numerous, but the infant river throughout that district is a very close borough. Here, as in the Test, the angler has all his work cut out for him; hence, to those who knew the waters it was no mystery that certain Hampshire gentlemen, upon being informed that the Tichborne Claimant was able to kill trout at Alresford, without more ado refused to believe he could by any stretch of possibility be a Wapping butcher. 
Just a word or two more- "Is the grayling an eatable fish?"

In reply to that query I would express the personal opinion that he is to be preferred to most descriptions of trout. He is never guilty of even a suspicion of mud, and he is in season when trout are not. The treatment given to the trout on the kitchen table and fire should be meted out to the grayling; therefore no more need be said. Save perhaps this :- are we not too much in the habit of spoiling the speckled beauty with fancy cooking, and unnecessary sauces? They held very sensible notions on this topic so: far back as I65I, when Thomas Barker advised :-

"For mark well, gond brother, what now I do say,

Sauce made of anchovies is an excellent way,

With oysters, and lemon, clove, nutmeg, and mace,

When the brave spotted trout hath been boyled apace,

With many sweet herbs." 


\section{CHAPTER VII.}

\section{THE ANGLER IN IRELAND.}

"The miles in this country much longer be ;

But that is a saving of time you see,

For two of our miles is aiqual to three,

Which shortens the road in a great degree."

Whether Ireiand be a better salmon country than Scotland, or Wales the best trouting land, is not the question; without any injustice to the bonnie Land o' Cakes, it may, however, I think, be taken for granted that the Emerald Isle is, on the whole, the Paradise of Anglers. Both Scotland and Ireland abound with beautiful streams and an abundance of fish, but in the latter country they are much more accessible to the passing stranger than in the former. It is more fashionable for the wealthy merchant or citizen to own an estate north of the Tweed than to possess one across the Irish Channel, and so it happens that rivers which in Ireland are absolutely free to the bonâ fide angler would fetch a high price and be jealously guarded in Scotland. Some day it may be that, in the revolutions of the whirligig which produces manners and customs, the fashion may run the other way, and then, while the bright charms of Ireland are rapturously acknowledged, the salmon and trout now free to the rodster may have as heavy a price put upon their heads as have their finny brethren of North Britain at the present moment.

Indeed already there is a slow change in this direction, 
and each year, such is the increasing love of angling amongst Englishmen, some river hitherto open to all comers is added to the list of private profit-yielding preserves. The natives, debarred for the first time in the history of their fathers from liberty to angle, naturally for a while deplore the loss of another of the few privileges which the hard times have left them; but happy, notwithstanding, are the people who have no worse grievance to groan under.

And there may, in re the Irish rivers, be added the consolation that many years must pass before any appreciable diminution can be suffered in the freedom which makes Ireland so desirable a ground for the angler who cannot pay a fancy price for his pleasures, or command an entire season of time in their leisurely pursuit. When driven from the plains he must flee to the mountains; when forced from the rivers he must retire to the loughs. This generation, at any rate, is likely to pass away before such an extremity is reached. And it should not be forgotten that while the value of Ireland for rod and gun is becoming more recognised by what may be termed the rank and file of sportsmen,the mighty men of valour, Nimrodical and piscatorial, having always been familiar with its advantages and accustomed to seek them in the wildest haunts-and while, as a consequence, shootings and fishings, especially the latter, are in growing demand, there are to be found, in almost every part of the country, many proprietors who keep and protect their fisheries as a legitimate attraction for visitors and residents. Even in instances of preservation of a pretty strict description, permission in Ireland is seldom refused, in moderation, to a stranger whose respectability is beyond question. 
After fishing in lough and river under the freest of conditions in a certain district in Ireland, I once found myself whipping a burn in the south of Scotland, having obtained permission so to do from the agent of the nobleman who owned the land. It was a nice little stream for want of a better, and at times, I was told, productive of fair sport. Guided by a local Waltonian whom I had attached to my service, I found myself in the course of my upward progress arrested by admiration of the fern-covered grounds with woods beyond, a few Highland cattle cropping the herbage, a setter or two barking in the distance, birds of prey hawking here and there, and purple mountains receding to a very distant background.

In the midst of my hearty enjoyment of the scene a youth appeared on the opposite bank, eyeglassed, knickerbockered, and haw-hawing. What right had I there? Where did I come from? What was my name? These and other questions, peremptorily demanded, were straightforwardly answered, and then sentence was pronounced. We were at once sent about our business by this lordly youth, who had talked of "my pwop'ty" until I assumed he was at the lowest a duke. Of course we shifted quarters immediately, and in trudging towards the boundary of what the young gentleman had called "the deer park,"-a strong stretch of the imagination, by the way-I discovered that our outraged landowner was the son of an English manufacturer who rented the place. No doubt he was a good son, and no doubt he had a perfect right to prevent any strolling vagabond from thinning out his troutlings; only, after some years' experience of Ireland, I cannot conceive it possible that any angler there, finding himself in a similar position 
(through another's error), and announcing his strangerhood, would have been made otherwise than courteously welcome, at least to finish the day he had begun.

Yet what an astonishing ignorance prevails respecting Ireland! "Is it safe ?" asked a broad-shouldered stockbroker of me, when with enthusiastic eloquence $I$ told him of the rare sport to be had in that tight little island.

"Is it safe to trust yourself into those savage parts?" he demanded.

1 The man of Consols was reeling in his live bait as he asked me the question by the side of a very private sheet of water (not many miles from the Royal Exchange) where I was lounging over an evening cigar, watching his efforts to get a "run." $\mathrm{He}$ admitted that he reserved $£_{5} 0$ yearly for a month's holiday, not a farthing more nor a fraction less, and always spent it. He was a bachelor, and gloried in being unblessed with wife or child. He had "done" the Rhine because Tompkins had done it. He had accompanied Smith to Paris, Jones to Germany, Buggins to Florence and Rome, and on each occasion, so he protested, he had felt relieved when at length the last of his ten-pound notes had been changed. But Ireland? No: he had never ventured there. Was it safe?

By an almost superhuman effort I converted him, and saw him off by the Wild Irishman, with a magnificent angling outfit, resolved at last to risk his precious body amongst the Irish rivers and lakes. At first I believe he never moved out without a revolver. The weapon now lies buried, like his ignorance and prejudice; full fathoms five. He had been an enthusiastic fisherman for twenty-two years, but swears he never knew what real angling meant till then. The twenty- 
pound salmon that arrived while the last meeting of his club. was being held was a little the worse for the journey from County Mayo to London, but it had been slain by his valiant self, albeit the members held their noses as they vehemently admired it. So ong as our worthy friend lives you may take odds he will spend his fifty pounds-he says it is difficult to get through so much in those parts-in the country of which he will never more ask "Is it safe?"

The lakes of County Clare offer probably the best pike fishing in the United Kingdom, and trout and salmon in the streams ; Kerry, with the waters of Killarney, is too well known to be more than mentioned; the Blackwater, Lee, and Bandon are sufficient of themselves to give Cork the highest reputation; and as for Limerick, why need go further than the Shannon?

"Oh Limerick, it is beautiful, as everybody knows, The River Shannon full of fish beside the city flows."

The Shannon, speaking roughly, is full of fish, and except the famed salmon stretch between Killaloe and Limerick, is free. White trout, brown trout, and monster pike and perch abound in the Shannon waters. As long as I live I shall probably never see such a sight as-if I remember accurately-at Athlone. The train had stopped outside the station on the bridge over the river just as it was clearing. after a flood, and bare-legged peasants were on the platform. with trays of spoil, great trout and perch, by the hundredweight, while below through the railings we could see the boats drifting down stream heaped up with recently caught. fish. Take it all in all I doubt whether there is a river in the world for "all-round" angling to equal this splendid stream, 
which sweeps through Leitrim and the eight counties intervening between its source and the Atlantic Ocean.

Dublin is singularly unfortunate in its fresh-water fishing, but it is a mistake to suppose that the angler is there entirely at fault. It is not so very far from Powerscourt with the romantic Dargle and its stores of merry little trout. There. are pike and perch in the Liffey below the strawberry gardens, and trout increase with your distance from incomparable Phœnix Park. The best spot I have always, however, found is under the Wicklow mountains near the source of the river. Kilbride, though a long drive from Dublin, is a very pleasant trip, and often have I compassed it on a jaunting car. The trout are always small, but they make atonement in their extraordinary quantity, and the voracity with which they take the somerwhat gaudy little flies by which they are tempted.

There are some events in life never to be forgotten. You may not remember your first drubbing at school, your first stand-up collar, your first shave, your first kiss, your first client, your first appearance in print, or the incidents, weather, and so on, of your wedding day; but you cannot forget your first salmon. What a delicious remembrance it is :

There was, to be sure, something a trifle curious about mine. I was at Galway, as interesting a town as any in Ireland, and, as every one who has looked over the railings of the bridge must know, a regular show-place for salmon. The bottom of the river seems paved with them, and you may be amused for hours, when the humour seizes the fish, by watching their antics as they shoot and circle and leap as if in the performance of a dance on the up-the-side-anddown-the-middle principle. At the eventful time to which I 
am referring the salmon fishing was over, for the Galway river is not one of the late kind. The proprietor of the fishery, however, with the ready courtesy of his class, freely allowed me to try my best for a brown trout, and wished me luck. This wish was gratified to my heart's content, and the little lad with the net had for a time no opportunity of dropping asleep. In the middle of the stream there was a shallow and placid pool, surrounded by water rippling in the usual way over the stones. The fish below had ceased moving, and observing in the middle of this space the familiar expanding rings caused by a rising fish, I despatched my cast athwart.

"Tug, tug" was instantly telegraphed down the butt of the rod: then there was a dull heavy strain.

Slowly at first, then at gathering speed, the small ebony winch made music. Straight across the pool, back again, here, there, and everywhere, the prey shot, churning the water into foam, and causing many arnth ...... leap into the air. Such a hullabaloo there never was. The boy shouted franticly. Workmen threw down their tools and rushed down, and in a few minutes a small crowd had collected. The fly rod was the lightest that could be made, the line finely tapered, the hooks extremely small, so that when half an hour had gone, and the evening had begun to absorb the light, and the commotion in the water to rage as before, hope of a satisfactory finale departed. Perseverance, however, gave me the victory, although the battle would probably have been on the other side had I not prevailed upon Tim to flounder into the water and net the fish as he ran. The wonder was how a five-pound salmon could have created such a stir! Stooping to claim him, I found out the cause : 
he had been hooked in the back fin with a small coachman! The water was so low that in drawing the cast towards me I had fouled him in that singular manner. And this was how I caught my first salmon.

The fishing in Galway is excellent, but the best has to be paid for at high rates, and the waters are not allowed too much rest. The great lakes-Corrib and Mask-contain all kinds of fish, but the sport is uncertain. The district is most interesting to the tourist, and the ride through Joyce's country one of the treats of the island. The circular tickets issued by the Midland Great Western Company are a bon $\hat{a}$ fide boon, saving you trouble, ensuring you comfort, and in every way reducing the inconveniences of travelling to a minimum.

Unless the waters are known to be in good order I should not, starting from Galway, advise an early halt for angling. The Spiddal, a river about ten miles from the town, is a fair wet-weather stream, and trolling in the lakes thereabouts is not to be despised; but on the whole you had better let your rod lie undisturbed in the well of O'Brien's roomy car, and enjoy your ride through Connemara as an ordinary Christian. Make the most of the Twelve Pins, envy Mr. Mitchell Henry his house and fishing at Kylemore, and go into raptures with Killery Bay, for of its degree you will meet with nothing to surpass it. If you cannot make yourself at home at Westport, in the hotel with the river and trees before the door, your conscience must be in a parlous state. You may be tempted here by what you hear of the fishing in Lord Sligo's demesne, and the chances of obtaining permission, but don't unstrap your rods, or unlock the basket, until you find yourself in due course at Ballina. 
The Moy, as an open salmon river, has no rival in Europe, and the only fault to be found with it is the general unhingeing one suffers on reading every week in one's English home a record of the fish taken. It is impossible to settle down to the duties of the day when, in the roaring Babel of London, you read how Captain A. killed his five, the Rev. B. his eight, and Sir John C. his ten fish, weighing so many pounds; and the most melancholy part of the business is, that you know it is certain to be true. After two visits to the Moy I am in a humour to believe almost any story of fishermen's luck there. The proprietors give you permission for the whole season, fettering you with conditions which are not only reasonable in themselves, but such as every real sportsman will rejoice to observe.

You are not required, as at some places in Ireland, to take out your licence in the district-of course there is no such thing as salmon fishing without a licence-but you are requested carefully to return the fry to the river, and to give up all the salmon taken, with the exception of one fish, as soon as possible after the capture, to the fishery store. There are good seasons and bad seasons on the Moy, as at the West End of London, but it must be indeed a hopeless case if either in the upper or lower waters, with a cast of friend Hearns's flies and a "cot" well handled, you cannot show trout or salmon as a reward for your labours. You may not be able, as Hearns can, or rather could do, to pitch your fly forty yards across the stream, or kill your hundred fish in an easy month, as some anglers have done aforetime, but something you can hardly fail to do.

Lough Gill is the most lovely lake in the north of Ireland, and I cioubt whether there is a lovelier in any part of the 
country. I passed that way four years ago, intending merely to sleep at Sligo and move on to Enniskillen in the morning, but three days had somehow gone before I called for my tavern bill. Too late for salmon, or trout in any quantity, I had some rare fun with the pike. The boatman who took me in charge was a famous fellow for a companion and "help," eager to please, glad at your success, and sympathetic with your reverses-in short, a model boatman for a long day's work. I have no doubt in the world there are pike of 4 olb. or 5 olb. in Lough Gill. A minute account was given to me of a couple of young men who had killed one of these giants and who had walked through the main street in triumph with an oar passed through its gills; the handle and blade resting upon their respective shoulders, they thus unconsciously imitated the spies sent out by Joshua, who, according to the ancient engravings which disfigure the pages of old-fashioned Bibles, returned with a huge bunch of grapes suspended in the same fashion as the great pike of Lough Gill.

They-that is, both the fishermen and the fish-are very fond of spoon bait on the lough, and a careful fishing of the river communicating with the lake will be no waste of time on your upward pull. Keep pretty close to the left bank and look out for the holes; from one little bend I took four pike in five casts, and Pat, who, like all Irish fishermen, looks upon every fish but salmon as mere vermin, knocked them on the head and consigned them to a hole in the fore part of the boat as if they were so much lumber. The "jack pike," as he termed pickerel of a pound or so, he was more careful with, designing them for bait by-and-l)y when we reached the lake. 
Is there one amongst my readers who can remember his state of mind when on some occasion he has been surrounded by the evidence of fish yet been unable to obtain one? That was my hapless condition during a spell of midday sun on the Garrogue River. It had stormed right royally when just previously the pike in mad succession took the glittering spoon, and then large circles spread upon the water showing that the trout were on the move. Even in Ireland, however, where brown trout are not accounted of ligh rank, you cannot in conscience meddle with them at Michaelmas. Pat pointed to me the direction of a deep pool where in the spring, he said, many a salmon was surprised, and where now he knew there was a shoal of perch of the genus "whopper." He had seen them the day before, "yer honner, shoining loike bars of gowld tied up with black ribbon, upon my sowl, sorr."

A phantom minnow should be in every wandering angler's case, and I should as soon think of going to Ireland without cne as without my pipe. The phantom, however, carelessly handled played me a trick which did not raise me in the boatman's estimation. A good perch was hooked, brought to within a couple of yards of the boat, and clumsily lost. I permitted him to approach the top of the water before his time; there was a pull-baker, pull-devil sensation, then a floundering on the surface, a broadside flashing, and a sudden disappearance. Pat had one or two provoking little ways with him. He had watched the whole business with positive eagerness, but the moment the misfortune happened he appeared unconscious of it, of me, nay, of himseli, as, looking quite in another direction, he gazed musingly at the sky, softly whistling. 
"Bad business that, Patrick?" I suggested shamefacedly.

"Och, and did ye miss that same, yer honner?" he asked with a magnificently assumed expression of surprise.

The salmon of Loch Gill are not as a rule large. The lake trout, which take the fly well up to the end of June and July, are both large and numerous; perch of about half a pound weight the boys and girls catch by the bushel, by fishing over the boat with a simple piece of string and hook, weighted with a pebble and baited with wormss. The pike also are abundant, much too abundant to please the keepers, who in the spawning season shoot them without mercy. There were two parties of pike fishermen out on the day of any visit. I would not care to commit myself to details, but I should think each boat had not less than a dozen rods sticking over its gunwales, elevated at an angle of forty degrees into the air so as to allow of all the lines trailing without fouling. Every now and then we could hear the whizz of the winch, and would pause to see the pike hauled in hand over hand. We had a nice heap in the bottom of our own boat when we landed at Pat's cabin that night, but what was one rod amongst so many? Pat seemed to think I took too low a view of life. He wished me to try for a big fish, and nothing but a big one. He persisted in the wish. Now, I have one invariable theory on this head, and I gave him the benefit of it.

"Pat," I said Johnsonianly, "I fish for sport, not gross weight. I would rather any day catch half a dozen moderately sized fish than one large one."

The man, it was plain, considered me an ass, but he merely looked up in his provoking way at the sky, and whistled 
again softly. At length, however, he was propitiated, for I proposed we should take a nip of "the crathur" for luck, fill our pipes for heart, and go in for the biggest fish in the lake. Then the good-humoured Patrick overhauled my spinning flights, selected one that would hold a whale, and adjusted it through and round about a "jack pike" of quite a pound weight. The plan was to trail it say forty yards at the stern of the boat, and I must confess that although it wobbled a good deal, and made a tremendous commotion in the water, it looked a most attractive mouthful for any pike-ish ogre that might be lurking near.

It so happens that Lough Gill is charged with glorious scenery, and while the pickerel was wobbling steadily after our boat I forgot the chances of sport, and became lost in poetical contemplation of one of the sweet wooded islets that bestud the water.

The moralist tells you truly indeed that in beauty there is fatality. Had this been a mere Dagenham pond who knows what a contribution would not have been made to the South Kensington Museum?

My knowledge on this point is vague, but shall I ever forget that savage pull which bent the top of my rod swiftly into the water, or that mighty swirl far away in our wake when the giant, snapping my thickly plaited silk as though it were cotton, went off with hooks, trace, and twenty yards of line, leaving me lamenting, and Pat a third time making astronomical investigations and screwing up his lips? It would have gratified me to have received a little consolation from my humble companion, but he was not going to belie his conscience for any one just then. And that was what came of admiring the beauties of nature, and not 
perceiving that the line was carelessly entangled in the handle of the winch.

Let us now change the scene to another lough across the country, the largest lake in the three kingdoms, and one of the first four largest in Europe. In considering the angler's opportunities in North Ireland it were almost a sin to deal slightingly with the splendid lakes and rivers of Donegal and Londonderry, but there is such a thing as space to be thought of when your notions are to be put in type, and that thought will intrude itself at this moment.

As a skeleton guide to angling in Ireland I can with a very clear conscience recommend the inquirer to the chapter devoted to that subject in Murray's Guide; and this is a tribute one all the more gladly pays, as a set-off against hard words provoked by the vices of such literature on other occasions. The compiler of this guide to the angling waters in Ireland had the good common sense to aim at nothing more attractive than the imparting of reliable information, and this he has certainly succeeded in getting and giving. Shifting my responsibility to those unknown shoulders, I therefore turn to the waters of which $I$ have had recent experience.

It has been the aim of these chapters, in a plain fashion, to hint to the angler the sport most suitable for each month, and that aim is not here forgotten. By October, on almost all waters, fly-fishing has become very scarce. There are, to be sure, sewin in Wales, and peel in Devonshire, and seatrout in various places; but the ordinary trout season is gone, and none but late salmon rivers remain. Pikefishing and all the coarser fish are now in their prime; but I shall conclude this sketch for the special benefit of any 
reader who would care to know where to obtain, without much trouble or expense, and with some reasonable chance of success, heavy trout and salmon fishing in October. If asked where such a spot is to be found, I reply- "Randalstown, near Lough Neagh."

There is a choice of routes from England to Belfast, and Belfast is well worth spending a day or two in for its own sake. Ulster is not only a flourishing province, but is interesting in its picturesqueness, and rich in historical associations. After the rapid railway travelling to which we have been used at home, the Irish lines doubtless are apt to be tedious ; and the short journey from Belfast to Randalstown is one of the most wearisome of any.

It is safest to purchase your flies at Belfast, for they are of a particular pattern, and the tackle makers there understand precisely what kinds are suitable for existing circumstances. A salmon licence may be obtained either at Belfast or Randalstown, but by all manner of means do not forget to include the wading stockings and brogues in your kit, else a beautiful piece of the river which, by stopping at the O'Neill Arms, you are at liberty to fish in the grounds of Shane's Castle, will be altogether beyond your reach.

The O'Neills have been mighty kings in Ulster, and their emblem, the red hand, will often meet the eye in Antrim. There are two inns well known to anglers visiting this part - of Ireland, and they are both O'Neill Arms, the one being at Randalstown, and the other at Toome Bridge; and the angler who cannot make himself at home at either ought to be kept on short commons until he comes to his proper senses. There is a delicious sense of freedom and coming pleasure on entering the passage of an angler's hotel, and 
being greeted, not by bagmen's trunks and sample boxes, but salmon and trout rods neatly ranged on the rack, and landing nets occupying every spare corner. What a thrill of anticipation passes through one when the landing net is damp from recent use, and bugled with the silver scales of the last captive! There is no inn in the world so comfortable as an honest angling house-a statement which holds equally good in the Highlands, by the waters of Ireland, among the mountains of Wales, or on the banks of the English rivers.

The fishing in Lough Neagh is mostly a matter of nets. I heard a few sly whispers of what was done sometimes on windy days by cross fishing, and saw evidences (of which no more) which rather set at nought the fishermen's ruling that little, if anything, can be done with a fly on that one hundred and fifty-four square miles of fresh water. At the O'Neill Arms at Toome Bridge I saw, with my own individual eyes, a magnificent lake trout of sixteen pounds taken that morning by net from the lake, and in the recess of one of the coffee-room windows there lies under a glass case a stuffed specimen of the same family, labelled " $261 \mathrm{lb}$." Trolling and spinning are the best methods of angling for the Lough Neagh trout and pike.

The fishermen do a great deal with night lines baited with scraps of pullan, the fresh-water herring which abounds here, and which one boatman told me was often found on the cross lines. This must be a very exceptional circumstance, seeing that the flies used in this poacher's contrivance are almost as large as salmon flies. The lake is famous for delicious eels, and hundredweights of them are despatched to England by an English lessee who has purchased the fishery. 
At Antrim a river known as the Six Mile Water runs into the lough. Other streams feed the lake, but only the River Bann, a capital salmon river, carries its waters to the sea. I made my first bow to Lough Neagh from the Antrim end, and in that same Six Mile Water there should be, unless the shrewd lad who witnessed my loss has since recovered it, a derelict Canadian spoon-bait which caught a snag instead of a fish. The fishermen use a stiff open boat that carries a good press of sail, and if you can catch a mild breeze a trip across to the opposite shore should be unfortunate for the pike and an occasional trout. The Six Mile Water used to be an excellent salmon and trout stream, but it has been poisoned time after time by mills and factories, and is now in its lower portion scarcely worth the trouble of fishing.

An idle day - that is to say, a day on a boat on Lough Neagh, with a couple of spinning baits to take care of themselves, the glamour of sunshine over the woods and shores, and a sweet bell-like voice reading softly to you (as the incense of the meerschaum slowly ascends into the clear atmosphere) about the legend of Shane's Castle, and the traditions of the lake and land-is a penance one would risk not a little to suffer. After three days' conscientious whipping and wading at Randalstown or Toome Bridge a rightminded man should find it quite bearable to be petted and read to for a few hours while reclining lazily in the roomy stern-sheets of a Lough Neagh fishing boat.

The Main is a river after the angler's own heart, especially in September and October. Visit it in August, and your execrations are likely to be as deep as the rolling Zuyder Zee. The flax plant is an interesting object no doubt, and useful withal. In June when the pretty blue flowers are in 
blossom you may become even sentimental over it ; in July the ripe crop may give joy to the farmer, and satisfaction to Dorothy his wife. But the angler has another tale to tell. It will be years before I shall reconcile myself to Irish linen, so deadly is my hatred of the flax water of which I had painful experience. All Ulster anglers curse the flax water if they curse nothing else, and if they do not speak their condemnation they think it. The cut flax is placed in water pits to soak, and the filthy trenches being drained off when the soaking is complete, the rivers become discoloured, the air is polluted with a stench to which that of a tanyard is otto of roses; the fish are sickened to death's door. Luckily they do not die under the infliction, but they never move or feed, and the experienced angler at once puts his rod on the rack. The only fish that affects unconcern at the appearance of flax water is the impudent little samlet, which bolts a fly as big as its own head, and worries you incessantly at all times.

The Main river is noted for heavy trout. When I crossed the bridge on my way from the railway station my heart gave a bound at what I saw. A lad was sauntering homewards dangling, with his fingers thrust into the gills, a trout of some four or five pounds; a young working man drifting with the stream in a boat checked by a pickaxe slung over the bow was taking trout on an average at every third cast ; further up on the meadow banks I saw the well balanced figure of the trout fisher. Eager as the traditional war horse is said to be for the battle, I hastened to the river side, sniffing carnage as I ran. It was at the close of a day's rain, the first that had fallen for a month, and the river, though slightly coloured, was in superb order. It ran by in 
stately measure, broke out like a Christmas carol upon the scours, tussled and fought round the big boulders, and postured like a dancing master round the curve of the pools.

And how the fish rose for one little hour! Old Tim in the potato garden over the way, young Mick knee deep in water, Squire Brown in the rushes, the ductor under the weir, the captain in the quiet part of the stream-one and all kept up a pretty hoorooing while the game lasted. The stranger, latest arrived, although his flies were all wrong, and he had in his blind haste got in the teeth of the wind, shared in the general good fortune, and wet, muddy, and tired returned to the inn at dark with the strap of his creel cutting into his shoulder. It was a carnival of trout, large and small, brown and yellow.

On the following morning it must have been highly amusing to the non-angling spectator to see the blank countenances of the expectant sportsmen who at daybreak went. down to the waterside. A turbid, ochre-tainted flood had arisen during the night, and, too vexed to speak, they returned without taking the rods out of their cases. Allowing a week of fine weather to interpose, I again went to Randalstown, expecting naturally to find the flood abated. So it was, but there was a dark umber stain in the water which I could not understand until I was informed that this was the flax pollution, and that I might as well attempt to fish in a water butt. The warning was amply justified, for after nine hours' severe labour I was the richer by about three ounces of trout.

On my next visit I was more fortunate. Rumours of half a hundredweight of salmon in one day caught by one rod, exaggerated though no doubt they were, might still be true, 
and for salmon I tried heart and hand. About two miles up the river the Fates whispered me good omens. The stream, running sharply across from a pretty coppice, swept in a long, deep, semi-circular pool under a steep rock-shelved bank, and feathered away in a foamy tail. A cloud went across the sun, the wind ruffled the dark water, and the favourite claret fly dropped down upon the precise square inch that would bear it in natural motion into the current.

" Let the proud salmon gorge the feather'd hook, Then strike, and then you have him-He will wince :

Spin out your line that it will whistle from you Some twenty yards or so, yet you shall have him. Marry! you must have patience-the stout rock Which is his trust hath edges something sharp; And the deep pool hath ooze and sludge enough To mar your fishing-'less you are more careful."

Doubtless! but we are careful, though twice twenty yards are run out in one jubilant fanfare from the click reel before there is time to think of patience, or sharp edges, or anything else but the pleasant tingling which the taut line has communicated to every nerve. The gallant fish evidently loves the shade, for he has shot up to the plantation's edge, cleaving the water as he took the narrowest part of the channel. He is partial to gymnastic exercises too, for into the air he purls, sending one's heart into one's mouth for fear. But he is too well hooked, and being closely followed he returns back again to the pool, to yield up the ghost perhaps in sight of a comrade who may by his fate take a salutary warning. I don't say an eight-pound fish was much to brag about, but with only an ordinary trout rod and a landing net, which you must perforce use yourself, it did not come amiss to the captor. 
It is, however, as I have before said, in September and October that the best sport is obtained in the Main river. Great trout up to twelve and fifteen pounds then run out of Lough Neagh, and salmon also; and there is a numerous congregation of anglers from all parts of the country so long as the sport lasts. But the Main is not what it was, and a bare-legged peasant woman confidentially told me why: a few years since a gentleman from London came and took out certain fish, from which he extracted the spawn, and returned them again to the stream. For a couple of days, she said, there were strange disturbances in the pools, as if the fish were sitting in conference on the business. The end of it was that on the evening of the second day, as she was leading her goat to new pasture, she observed a movement on the surface as if an orderly procession were passing down the middle of the river. It was not for her to judge, she concluded, but her private belief was that the fish so summarily deprived of their spawn had, in dignified resentment, retreated into the lake, never more to return.

At Toome Bridge there is a beautiful stretch of trouting water. The waters of the lough, broad and clear here, tumble over a weir forming the vigorously rocked cradle of the River Bann. Not only can you take fish close under the fall, but by bringing your boat to within a foot of the uproar you may cast your flies into the lake itself, and frequently hook a blithe two-pounder within a yard of the edge. Whether you land him or not is another business, for as he has a habit of projecting himself over the weir, the chances are more in his favour than yours.

This river must be fished from a boat, and it literally swarms with trout. Using fine tackle and small flies in 
favourable weather you may easily, take three or four dozen fellows ranging betwreen half a pound and a pound, witi. once now and then larger fish. It is a distinct specimen from the lake trout, which cuts as red as a salmon and has a salmon flavour; these yellow river fish are neither so wels coloured nor flavoured.

On my last evening at Toome I saw a most wonderful sight. In the west, over the mountains, looking almost ethereal in the fading light, the sun was sinking into a world of golden cloud-architecture, at which one looked with a feeling akin to awe. Turrets were piled upon turrets, their tops gilded with a reddish hue; there were seas and mountains and forests in that mystic land of shadows, and they all melted into thin air like a dream. Directly eastward, on turning from this glorious pageantry, I found the moon rising full and weird out of a bank of dark purple clouds which brooded over that portion of the lake. The moonrising was as wonderful in its way as the sunset, and appeared, indeed, to be in sympathy with it. It seemed as if the Queen of Night had resolved to emulate the God of Day, and, from the dusk, carve out another such city as that which had faded in the western sky; but the attempt was not successful, and the moon, as if observing it, gave up the contest, and broke into a genial smile, which was. reflected in ripples of silver all over the lough.

\section{Practical Notes.}

Murray's Handbook has been mentioned in the preceding. chapter as a sensible guide to the angler in Ireland. The best angling work respecting the sister isle, to my know- 
ledge, is a volume entitled "A Year of Liberty," by W. Peard, M.D., LL.B. The doctor in the most spirited style records his experiences with the rod in Ireland from the ist of February to the Ist of November. The book, it is true, refers to the Irish waters of ten years ago, but having been within a couple of years on the author's track in many places, I can recommend the work as reliably applicable in its main features to the present time. Some years since I read, re-read, and then read again an old work entitled, if my memory faithfully serves me, "The Book of the Erne." It is an enchanting angling book, but scarce. For the tour through Connemara, from Sligo to Galway (angling may be picked up along the whole way), there is a very useful little skeleton-guide pamphlet-"Western Highlands (Connemara)," by Mr. E. B. Ivatts.

If the visitor to Ireland should return from the northeastern port of Belfast, and has a day or two to spend, and any capacity left for admiring fine scenery, I would advise him to select the route by Stranraer. He will then obtain a capital view of the lrish coast, of the rocky islands and headlands of Western Scotland, and he will also have the shortest possible voyage between the two countries. At Newton-Stewart, in the pleasant stewartry of Kirkcudbright, he will have the River Cree, and several tributary burns, some of which may be fished without much trouble. There are brook trout, and in the autumn white trout. Exquisite glens, mountains, and moorlands are near, and plenty of legends for the antiquarian and romancist; for the angler, who is prepared to wander onwards and upwards, there are lochs with an abundance of finny inhabitants. The country between the Cree and Nith is 
of an imposing Dartmoor type, veined from summit to valley by many a tumbling brook, and peopled with famous Galloway cattle, and black-faced mountain sheep, nimble as goats. Castle Douglas is another convenient halting-place, and Dumfries, the interesting town on the Nith, where Burns wandered, worked, and died, should arrest the progress of one who has not previously made acquaintance with it. 


\section{CHAP'TER VIII.}

\section{PIKE-FISHING.}

"He headlong shoots beneath the dashing tide, The trembling fins the boiling wave divide:

Now hope exalts the fisher's beating heart;

Now, he turns pale, and fears his dubious art; He views the trembling fish with longing eyes,

While the line stretches with th' unwieldy prize."

THE bonâ fide angler knows no season but that prescribed by the laws of fence, and the pike-fisher is the hardy annual of sportsmen. When others lay themselves, like ships out of commission, high and dry in dock, he is on the alert. There is this to be said in his favour:-When on a dark gloomy November day he sallies forth to the slushy water meads he has nothing but his love of sport to sustain him. Enthusiastic adorers of the beauties of nature may venture upon stretching a point to unusual limits, but they would overstep the mark sadly if they sought to glorify or find anything to laud in the month of short days and foggy nights. -

"Who loves not Autumn's joyous round, When corn and wine and oil abound? Yet who would choose, however gay, A year of unrenewed decay?"

Who, indeed ? Not the pike-fisher. Tourists have come home like birds to their roosts; the Michaelmas daisies, in their pale funereal lavender, have had their day; the 
chrysanthemums have brilliantly brought up the rear of the year's floral march, the first fire has been kindled at home, and our lamps are trimmed for the winter campaign. Most people have cast aside thoughts of out-of-door delight, and settled down to ordinary pursuits till spring. But the pikefisher suffers no interruption in his favourite pastime; rather, after Michaelmas he looks forward to four months of prime sport.

He has, supposing he began in August, seen the corn embrowned by the sun; has, standing by the river-side while the pike is taking its time in gorging the live bait, observed the reapers thrust in their sickles, and the women and children gather up the sheaves; has, while trudging through the lane that offers the shortest cut to the station, been compelled to turn into a gateway to give room for the passage of the harvest-home wain, from which he has plucked half a dozen ears of golden grain to bear away as a trophy; has seen the walnut-tree thrashed, and the apple orchard glowing with pyramids of mellow fruit; has noticed the bright patches of pale yellow in the branches of the elm-tree, and the rapidly changing hues of the chestnuter first signs of the coming leaf-fall ; has on the thatched roofs in the villages marked the assemblage of the swallow tribe, marshalling day by day until the final flight darkens the air ; has, in the fields and hedgerows, observed the wild flowers reduced to a few stragglers fretting mournfully in the wind to follow the gaily-uniformed main army has looked upon the quaker-like drab of the meads, the "burn' ing crimson of haw and hip, the bead-glimmering blackberry; has noted the rapid gradations of the bracken and fern from boldest green to faintesto primrose; has admired 
the sturdy oak keeping up an appearance of vitality long after its compeers have succumbed, until with a few plucky withstandings of the blast it itself gives in, shivering and heartbroken.

A!l these have been marshalled before his review, and he concludes that on the whole, though the autumn in its ripeness may be more enjoyable and beauteous than the uncertain spring and too hot-blooded summer, he would certainly not vote for a year of unrenewed decay; he knows that when the water-weeds begin to rot and drift away from their roots the fish move into deep water and are more amenable to piscatorial discipline than they were in the days when cover was plentiful.

Let us, therefore, court practical thought of the sport which yet remains when all else worth troubling about has been suspended. By November the last salmon and trout, to which we have aforetime borne good will and faithful testimony, have fully retired into winter quarters and winter occupations, and the best that remains for the angler are the fresh-water shark and the grayling. Roach, dace, and perch are in good, some think the very best of condition in the late autumn months, but bottom-fishing in the cold and damp, while a fair test of devotion and hardihood, will reign oyer a comparatively limited constituency, since there are-toradapt a simile from an old Puritan-hosts of fairweather anglers as well as fair-weather Christians. Pikefishing, therefore, stands far ahead on the catalogue of winter opportunities.

- Even that spartsman who sneers at humbler members of the craft; and pretends to faint at the sight of a worm, condescends accasionally to make advances to the pike, and. 
many are the country-houses where a Brobdingnagian specimen is encased as proof of the prowess of the squire, the captain, or his lordship. In their condemnation of "Cockneys" the upper ten of the angling world do not include the wielder of trolling or spinning rod, though they may look askance at a bait-can. The pike, more even than salmon or trout, touches the fisherman nature, and makes us all kin. And this for several and obvious reasons.

The fish is the largest of the coarser denizens of our waters, and as such appeals to the sportsman who likes to kill something that cannot be whisked like a minnow over his shoulder; and there is always the possibility, although experience generally reduces the probability to a minimum, of a great prize to be remembered as long as he lives and handed down to posterity as a sacred heir-loom. The pike is, moreover, a heartless scoundrel who sticks at nothing; the laws relating to infanticide he regards not; and if some of the legends of our boyhood's books are truth, he is an ogre more atrocious than the late Fee-fi-fo-fum, who, we have been assured, drove a thriving trade in the bonegrinding business. He is the enemy of all other finsters, and rests not until he has worried and pouched everything within his reach. $\mathrm{He}$ is much more artful than some persons suppose him to be, and has to be captured with a considerable amount of guile, and if taken in a sportsmanlike manner (of which more presently) battles fairly for his life.

A ferocious fish of prey, he merits no mercy, for he gives none, and is of the class which is doomed to perish by the weapon by which it lives. $\mathrm{He}$ is furthermore abundant in most waters, especially in England, and the Government as 
yet have not protected him with licence. Finally, to stop short in an enumeration which might easily be extended, he is, numerous assertions notwithstanding, worthy of respect as an article of food. It might be urged that his appearance, his wolfish eyes and sharkish jaws, are against him; but what would become of us, good reader, if we were each and all judged by our looks? Besides, I have said enough to prove how and why the pike should be every angler's game.

Think kindly of Esox Lucius, if only for the quaint stories -ay, and truly wonderful stories-to which he has from time immemorial given rise. It has been said that he is bred from weeds by the help of the sun's heat; that men and maids have been attacked by him; that he has lived through two generations; that he flies at mules coming down to drink, and maintains a bull-dog grip until, dragged out, the animal's owner takes him off; that he has fought duels with otters for carp captured by the latter; that he possesses a natural balsam or antidote against all poison; that a watch with a ribbon and two seals attached has been taken by an astonished cook out of his capacious maw; that in a pool about nine yards deep, which had not been fished for ages, a pike was, amidst hundreds of spectators, drawn out by a rope fastened round his head and gills, which pike weighed one hundred and seventy pounds, and had previously pulled the clerk of the parish into the water; that fox cubs and waterfowl have been received at one fell bolt into his ravenous gullet.

This and more also, is it not written in that best of all Waltonian chronicles - the edition enriched by the experience of "Ephemera"? And it is hard to say what is true and 
what false when the voracity of the pike is the question under consideration. Stories almost as marvellous as any of the above you may hear to the present day, vouched for as true by modern anglers. At the first blush you laugh to scorn the narration which gives the weight of a pike at I 7 olb. - a pretty sensational return as things go ; but judging from the rate of growth, constitution, and general character, there is no reason for drawing the hard and fast line at say thirty pounds. I have perfect faith in the oft-repeated assurance that in Holland, Germany, and Ireland fish up to sixty pounds may be-of course as exceptional examplesmet with. Still, if the pike-fisher can average captives of eight pounds he has no reason to complain, and from what I have seen during the last year or two I suspect there are far too many anglers who are not ashamed to take and exhibit jack amongst which a miserable two-pounder is the premier sample.

Not the least source of pleasure to the pike-fisher is the opportunities which now and then fall in his way of visiting the parks of English landowners where the waters are strictly preserved. Such water usually takes the form of ornamental lakes, placed where it shall add new charm to the tall ancestral trees of the fair estate. I have in my mind's eye at the present moment one of these sheets of water where the abounding sport is not less enjoyable than the beautiful scenery and interesting historical associations. On one side the trees not only grow by the waterside, but hang over the lake in dense foliage always mirrored in the surface, and always lending new colour to it. Opposite stands an ancient rookery, from which, before the tender May leaves have become too fully developed, many a young cawer is tumbled 
out by a party of sportsmen, mostly farmers and tradesmen from the nearest town, who are permitted on two given days every year to hold a rook-shooting festival. A little to the rear of a level bright-green lawn, smooth as a billiardtable (when newlyinown by the noisy machine), half-hidden by hoary-trunked beeches, stand the ruins of a castle that was in its heyday "in Queen Elizabeth's time, and whose remains are now picturesque and covered by luxuriant ivy. Owls dwell there, bats in the summer time wheel in and out of the dusky remnants of goodly arches.

Pull your boat into the middle of the lake, and look away. to the south-east. Look beyond the home park as soon as. you have ceased to admire that peerless herd of Channel Islands cattle, whose representatives have worn red, blue, and yellow ribbons at famous agricultural shows. They are cattle, although you may be deceived by their sleek beauty into believing them to be deer. The deer are the specks that dot the green slope beyond the moat and fence which keep them to their own haunts, and on the crest, crowned by forest trees of every kind, is the spot I wish you to observe. This is where Oliver Cromwell is said to have surveyed the ground and planned his attack; and not far from yonder boat-house is a bit of broken ground where he planted his rude cannon and pounded away with partial success upon the castle. For a mile the lake thus extends amidst the scenery characteristic of English country life, scenery which cannot be matched in the wide world,-the scenery of an English gentleman's hereditary estate.

I linger over this scene because it is typical of hundreds of similar pictures scattered over our lovely English shires with such variations as history and locality enforce; and 
in each there will be some fascinating link with the past, some special charm, artificial or natural, to assert itself. Nor do I forget that in and out of yonder alleys two centuries ago there walked a great hero musing upon the strange adventures of his life and the temporary cloud which hung over his brilliant prospects. Probably we have been walking over the precise spot where Raleigh sat and wrote, and capturing the lineal descendants of the fish upon which he commented in the following :-

\section{"Here are no false entrapping baits \\ Too hasty for too hasty fates, \\ Unless it be \\ The fond credulity}

Of silly fish, the worldlings who still look

Upon the bait, but never on the hook."

Were I owner of such a fair piece of water as we find in every English park, or proprietor of a fishery to which angiers were admitted on payment, each recipient of permission to fish, friend or stranger, should be bound strictly to certain rules : for example, there should be no pikefishing till the Ist of October; all fish under three pounds should be returned to their native element; and very positively no gorge hooks, for either live or dead bait, should under any circumstance be allowed. This last, I am aware, would appear to be a severe rule, but it would apply to. every one alike and would be absolutely necessary if the smaller fish are to be returned to the water. Snap-fishing is the fairest and most sportsmanlike way of capturing pike; and though it would be too much to say that it is the only method a real sportsman would adopt, it is certainly the artistic thing to do. 
It may appear strange after this-but what is there in this inconsistent world more inconsistent than human nature? - to sing the praises of trolling with the dead gorge, and to confess that in eight expeditions out of a dozen it is the mode to which I give preference. In this I am dealing only with rivers governed by no such rules as the above. If the gorge hook were prohibited no one would more cheerfully adhere to the regulations than myself, but where the majority of anglers use it in one of its two possible forms, it would be an unnecessary self-denial to place oneself at a disadvantage with one's fellows. It can scarcely be gainsaid that trolling is the pleasantest and surest fashion in pike-fishing. It is pleasantest because it offers the advantage of perpetual motion with the minimum of toil; it is surest because you can cover all ground and go to the fish instead of leaving the fish to come to you.

Many experienced men maintain that more fish are taken by spinning; on the whole, however, and taking one day with another, this I have not found to be the case. There are times when the fish lie close and lazy in holes and nooks where the spinning flight passes above them, or at too great a distance to tempt them, in their then state of mind, from their shelter. They are like Mr. Gladstone with the House of Lords; they will think over the business, and by that time, lo ! the bait has been whisked out of reach and sight.

The dead fish dropped carefully, and worked in an artistically up and down movement, to their own level and immediately before them, leaves no time for reflection. Their sharklike instincts prompt an instantaneous dart, and 
the murderous jaws snap in a moment across the middle of the bait. True, after being retained and run hither and thither, you may be mortified to find your free gift rejected and returned to your hands mangled, but you have had the excitement of the "run," which is not the less exciting because it is succeeded by the blank of disappointment. You may, and you naturally do, condemn yourself into thinking that, had you been spinning, the fish would have been all the same yours; why not, in the absence of proof to the contrary, console yourself with the reflection that he lay perdu between two banks of weeds either of which would have caught your triangles, to your loss of time and perhaps property?

There is-but all these opinions are deferentially advanced, be it understood-more variety in the oldfashioned art of trolling than in the modern science of spinning. To spin at all successfully you must keep up a certain uniform speed, and where there are weeds (the normal condition of pike waters) you cannot work very near the bottom. The troller has therefore more to study, and must regulate the rate at which he moves his bait by the colour of the water, the strength of the current, and the force of the wind. $\mathrm{He}$ may pause now and then to look about him, and dawdle in his employment. The spinner must slacken not, neither must his eyes wander from his line. Take a couple of men who have been pursuing the different methods during the day, and examine the righthand forefinger of each, and it will be strange if the spinner cannot produce certain red, raw diagonal stripes as witnesses to the truth of my argument.

Sometimes you will find it necessary to let the bait at 
every cast touch and for a moment rest upon the bottom, at others you may impart to it a spinning action. Trollers often make the mistake of working with too much haste, and others fall into the opposite extreme. The middle course here, as in most human affairs, pays best. Trolling has many of the advantages of fly-fishing. With your bag to your back and your gaff stuck into your girdle, you may move through the enemy's country unencumbered with baggage, free to come and go, to keep on or to halt, as inclination may suggest and occasion require. Booted to the thigh in trolling equipment, with nothing more than your trace book, bait box, flask, and waterproofs over the shoulder, there is nothing after fly-fishing so pleasure-giving as to wander by the side of a river with a light trolling rod in your hand. In some parts of the Midland district the anglers use a singular rod of not more than nine feet long for trolling. It is quite stiff, which I take to be a fault, but the owners can throw an immense distance and quite accurately with it. The chief objection to this weapon. is that it is useful for nothing else except live bait fishing with the gorge.

And how conveniently that little interval when the "run" is under weigh comes in! The angler never fills his pipe so proudly, so serenely, so full of hope and determination as when, satisfying himself that the line is free in the rings, and the winch handle clear of twigs, grass, and other obstacles, he lays down the rod to allow the candidate for his gaff to pouch in undisturbed confidence. If the run comes to nothing he does not give up in despair. Perhaps the points of the hook have not been rank enough, perhaps too rank, perhaps the lead has been felt and the fish rendered suspicious. He therefore tries him a second time 
with a brighter bait, and should he still refuse thinks no more of the matter.

There are a few primary conditions which may be insisted upon in pike-fishing at all times, and more particularly as regards trolling. The tail of the bait should always be closely tied and the protruding spines cleanly cut off. A slovenly angler loses half the battle. The veteran jack-fisher whose pupil I was proud to be, and who has sworn by trolling as against spinning for half a century with unfailing success, would never fix loop to swivel until the gills as well as the tail were neatly tied under the shanks of the hook, and certainly if the slight amount of extra trouble this gives does little good, it can do no harm. But I have met with several instances where, for want of this little nail, the shoe has been lost.

Again, never treat the pike family as if they were arrant fools. We take it too much for granted that anything will do for pike and perch. Thus it is amazing to behold the clumsy gimp and massive tackle used, fair weather and foul, by men wh. : you would reasonably expect to have more discretion. In clouded water use anything that comes uppermost, but under unfavourable circumstances as much care should be taken as with the more wary tribes of fish. Walk along close to the edge of a pike water and see how at your. approach the fish rush away. Instead of assuming that the pike fears and cares for nothing, act always as if he were as shy as a carp, and you lose nothing, while the certainty is that you will be a frequent gainer.

To keep as far from the water as possible, at first at any rate, is a precaution I would recommend to every one. Begin with a cast that is really no cast at all; that is to say, 
noiselessly drop-not throw-the bait as near the bank as you can, then begin to cast in successive lengths at will. The man who thus approaches water which has been unapproached on the same day stands an excellent chance of making acquaintance with the prowlers who lie under the overhanging banks, or who have come to the shallows for small fry. More pike in an ordinarily deep river are taken in this way within six feet of the shore than further afield.

Then as to gorging. Very whimsical are the notions prevailing on this head. I know of many persons who literally take out their watches at the first signal of a run, and be the movement of a fish what it may, strike home as soon as ten minutes have elapsed. A very old young gentleman I could name gives precisely fifteen minutes' grace. Now, it is indisputable that if the fish has gorged there is no danger of losing him, but at the same time I would submit that this waste of time in a short winter's day is quite unnecessary if the habits of the creature be sufficiently studied. It is every pike-fisher's experience that quantities of fish are lost by striking too soon. Most experienced trollers I think will agree with me that if the gorging process be not complete in a quarter of an hour it will never be effected, since Esox Lucius is only making sport of you, instead of you of him; also that at times the fish are in no haste to close the transaction.

Hit or miss I always proceed thus:-Tug, tug, and a rush. That is a run. The fish may stop soon, or he may run fifty or a hundred yards. The assumption may usually be taken, however, that a pike is not far from his temporary iair, and I very much question whether, when the line 
unreels at great length, the fish has not swallowed the bait almost at a gulp. However, there is the run, and the fish has stopped. Should he after a momentary pause move off, and stop again, only to continue his journey after another equally brief halt, the run is not over. By-and-by one, two, three, five minutes pass with no further movement except a scarcely perceptible vibration of the line, should there be little or no slack out. Whenever the fish now moves off I tighten, strike very gently, and winch in; and I venture to say in the majority of cases there will be a fish at the end of the line. This, like any other suggestion, may fail in application, but I have found it in the main reliable. Quite as often as not the entire transaction of run, pouch, strike, alid capture might be effected within five or eight minutes.

Live baiting is a deadly operation sometimes, and an exciting one if the bait is affixed to snap-tackle-that is to say, a small hook thrust under the back fin, and one or two triangles (one on each side) hanging level with or slightly below the belly. On lakes, or broad rivers where a thirtyyard cast is desirable, it requires not a little skill to haul in the line until you have the requisite tautness for striking, because striking at these times must be sharp. This style of fishing in a narrow river abounding with deep holes which can be brought nearly under the point of the rod gives wonderfully good sport, and is figuratively as well as literally above board. Dace for live baiting, as for spinning and trolling, are immeasurably beyond roach, gudgeon, or trout as baits, and next to dace a large gudgeon will be found most lively and hardy.

The use of the live gorge hook threddled under the skin suits the idle man, or the unskilful, to the letter. Open 
confession compels me to admit that I often fall back upon it, but never without the guilty feeling that after all it is next door to poaching, and that I am for the time a mere trimmer-fisherman. No pot-hunter should be, or ever is, without it. There is small skill connected with a process where the fish does all the work. It has not the excuse of trolling, in which the chief art is how to find your fish. The live bait wriggles and swims, the jack comes from near or far, and, after inspection, takes it. After the lapse of the usual time you haul in and lift him into the boat. Compare his feeble attempts to escape with the play given by a fish hooked only in his horny, prickly mouth. There is no comparison, and when you hear men lamenting that in this sort of live baiting they have been "broken away"-that is the regulation phrase-you need not be perplexed if you are somewhat puzzled how to estimate their skill as anglers. Assuming that every pike-fisher deserving the name subjects his line, traces, swivels, and hooks to a smart testing strain before he begins, and that they are of ordinary strength, it is difficult to conceive how a pike with a couple of hooks deep in his gullet tearing at his vitals can, with ordinary patience, break violently away. Grant the fellow time, and he may be turned up like a log.

Norfolk, which used to be one of the best pike counties in England, is being ruined for the angler by the unsportsmanlike "liggering" or trimmer-fishing practised there. The famous Broads on the eastern side are subject to a wholesale system of poaching. Here is an instance. In 1873 a party of men obtained permission to fish a private Broad, and set out from the capital city with an immense supply of live baits and a cargo of trimmers. They never 
put rod together, scorning such a namby-pamby fashion of fishing. Within a couple of hours of their pushing off from shore, between eighty and ninety trimmers were bobbing upon the surface of the water, and for the remainder of the day the men were incessantly occupied in rowing from trimmer to trimmer and hauling in the spoil. The fish happened to be in one of those hungry humours when there seems to be scarcely any bounds to their voracity, and at the end of the day the "sportsmen" were compelled to hire a farmer's cart to take home the booty. At a loss to know how to dispose of the quantity, they sold it in open market at twopence per pound. By accident the owner of the Broad, next morning, passed by the stall, and was naturally arrested by the novel sight. When he carelessly inquired where the fish came from, and was informed-for the fellows had not the cunning to keep their own counselthat they were the representatives of his own domain, his astonishment and anger may be imagined.

Once more let me confess to preaching where I do not always practise. On one Allhallows Day I had the opportunity of fishing a small lake under the Chiltern Hills. There had been a remarkably sharp frost for that time of the year, and there was, over the narrow mouth of the reservoir, ice a third of an inch thick, which took full half an hour to cut through with a punt. The morning was a simple blank. Dace curled by the best spinning flights to be procured. Artificial gudgeon and minnows, and spoon bait, were tried, and there was not a sign of success. The luncheon hour found us weary and despairing: a live roach was then tried with the usual gorge hook, whose gimp was passed from the shoulder under the side skin, out of the 
back not far from the tail. Before the cold meat was fairly removed from the napkin the float wint off like an arrow, and this proved a keynote to which a rattling tune was played for the rest of the day.

Not only was the afternoon's sport good, but the surroundings were themselves most delightful. The keeper was out with his dogs and punt seeking wild ducks, and as the birds took a good deal of shooting, and the fowler did not stop until he had four brace, besides a couple of coots, there was plenty to look at between the disappearances of the great crimson float. Another source of observation was the effect of the frost upon the trees.

"It shook the sere leaves from the wood As if a storm passed by."

The wind was a mere breath, and that at fitful intervals, but whenever the breath came, like a passing sigh, the rustling of the leaves which had been stricken by the frost, and the tremor and haste of their flight to the ground, were most curious to behold. In the morning the bit of lawn between the keeper's house and the landing steps was bare : in the evening it was ankle deep in the dark-brown dead leaves shed by the horse-chestnut trees. Of my "take" I will only say that a new rush basket had to be purchased to convey it to town, and that some unknown friend thought it worth a paragraph in the columns of a certain sporting journal. During the day, at another end of the lake, a party of merry gentlemen had been laughing and shouting and singing, so much so that it never occurred to me that they could be prospering much with their rods. They had scarcely moved from one spot, but they came in at dusk with seventy pounds of fish between them. 
Spinning demands, last, but as I have already suggested, not least, some notice. Many high-class anglers disdain to fish for pike in any other way. There are several kinds of flights recommended as superior to all others, but so long as the bait spins and there is something dangerous at its vent - there or thereabouts - it does not signify much. A large strong triangle at the end of a short length of gimp, passed into the vent and out of the mouth of the bait, is used at all times by various friends of my own, who declare it surpasses every invention that has been devised. Others give the palm to a succession of the most terrible triangles; others use nothing but artificial baits. There are inventions by Francis, Pennell, Otter, and I know not how many others, and they are all good, and all worth a trial.

The pike-fisher's box should contain two or three flights for natural bait, a spoon, a large phantom minnow, and a medium sized artificial dace; having these he need not remain at home because the live-bait can has returned empty from the tackle-shop. Spinning from boat or bank does not require the extreme length of line supposed by some to be necessary, and young beginners may to an erroneous conception of what is here essential trace the inextricable tangles which act so prejudicially against the temper and which send their bait round about their ears instead of twenty yards off as they had fondly hoped.

Let it never be forgotten that a short line cleanly cast, and a bait splashing little, and spun back well under hand, are more effective a hundred times than a sensational hurl into space; also that to clear your way as you go and render yourself able to stand close to the edge of the water, a preliminary cast right and left about a yard from and parallel 
with the bank should be essayed. Where rushes fringe the river this precaution should never be omitted. Time and practice alone make a good spinner, and there are veteran anglers who, chiefs at trolling, are in the last rank as spinners. On the other hand, a masterful spinner is more likely to be an effective troller.

Spinning may not be the pleasantest or surest, but there can be no hesitation in pronouncing it the most artistic method of pike-fishing. But there is spinning and spinning, and many men delude themselves into the fancy that their clumsy splatter-dashing is the correct thing. The best spinner is he who, like Caleb Plummer, goes as near to nature as possible. Spinning with the artificial contrivance makes you independent of the bait nuisance. Procuring bait, dead or alive, is, as many of my readers will ruefully admit, frequently a more formidable undertaking than getting the pike, and to travel a distance either in train or dogcart, on foot or. on horseback, with a can full of splashing fish that will give up the ghoșt unless the water be continually changed, is a penalty and not a pleasure.

The various spoonbaits, phantom fish, shadowy fancies, and well made imitations of a more substantial nature, are so numerous and cheap, and answer the main purpose of sport so well, that the spinner may laugh at contingencies which give infinite trouble to trollers and live baiters. The fish angled for-who, after all, is not a totally disinterested party-has a better chance also, and the fisherman having arrested his prisoner is able to exercise a very summary jurisdiction upon him. However, on the question of pikefishing, opinions will.always differ, and pike-fishers, touching the respective methods which this sketch has suggested, will, 
let me hope, agree to differ and object, if it shall so please them, with that urbanity and gentleness of spirit which from the beginning has characterised their fraternity.

A serio-comic incident which occurred to me once upon a time while spinning I cannot forbear recounting. Hearing that in the small reservoirs attached to some print works near Manchester there were pike, I soon procured the manufacturer's permission, and started off from the metropolis of cotton-dom with nothing but an artificial trout as bait. It had never been remarkable for its perfection, and after long use had become battered out of shape and colour. All the reservoirs but one were carefully spun over with the unlikely machine to no purpose. In the last a fish beyond doubt struck at it four times in succession, and mightily puzzled was I that nothing more productive had resulted. An inspection, however, showed that the loose triangles over the shoulder had not a sharp point between them, and it became necessary with a bit of thread, and in a very roughand-ready manner, to substitute for them the more prickly tail triangle. At the next spin I hooked my gentleman-a long, gaunt, wretchedly-coloured fish, with a body as thin as a hake's. Not another "touch" was received during the remainder of the afternoon, and I departed with my faminestricken wretch in the basket. Three months later at a junction railway station in Lancashire I fell into conversation with a homeward-bound party of anglers whose rods and baskets I considered sufficient warrant for self-introduction. By-and-by I told the story of the starved pike, starved as I was now able to say, for I had dissected him to discover the cause of his preternatural lankiness. A middleaged man broke forth into lamentation- 
"Eh! mon, and wur it thee that tuk it? Aw looved yon fish gradely, that aw did."

To the end of my days I may not forget the pathetic melancholy of that man's tone and countenance. After he had mourned in silence awhile I brought him round-by the aid of the refreshment counter-and the murder came out. In one of his fishing trips at holiday time he had captured a pikelet while angling for roach, had brought it home, deposited it in the reservoir, and fed it tenderly. The pike throve, and, according to his narrative, some intimacy sprang up between them; he saddened as he remembered how the fish would come to the side to be fed, and firmly believed that it knew as well as he did when the Easter and Whitsuntide holidays, and a consequent glut of gudgeon and minnows, drew near. By-and-by the man lost employment, and in his absence his wife, who had always personally disliked " $t$ ' varmint," left it to its own resources. During that unlucky interval my ruthless and fatal hand robbed the reservoir of its one inhabitant, and that inhabitant of its miserable life. The scant comfort left to Tim Bobbin was that the dark uncertainty as to its fate had been removed from his mind by my casual appearance on the junction platform.

\section{Practical Notes on Pike and Pike-Fishing.}

The season of $1874-5$ furnished numerous additions to our evidence respecting the weight of pike in English waters. The Thames yielded several fish over and above 2olb. weight, but the largest specimen was one of $35 \mathrm{lb}$. netted by one of the Royal keepers in Rapley Lake near 
Bagshot. I have seen several preserved specimens of fish of about 3 olb. weight in different parts of the country, but there are none to my knowledge so heavy as that mentioned above, of which Mr. Frank Buckland took a cast. We hear of exceptional pike of 4 olb., but the stories are generally second-hand. The fishmongers at Leadenhall have had Dutch pike up to $48 \mathrm{lb}$.

During the high floods that occurred in the Thames valley during the weeks succeeding the turn of the new year ( 1875 ), the pike-fishers were completely nonplussed. One of the best known amongst them went up the river as soon as there seemed to be a prospect of success, and found the water, to his disgust, in colour and consistency, not unlike pea-soup. All his efforts were unsuccessful till luncheon time. Then he moored the punt to the rushes in a position commanding a quiet eddy. $\mathrm{He}$ discarded the ordinary method of live-baiting, and, by affixing a heavy bullet a yard from the hook, improvised a rude ledgering apparatus. The result justified his choice of both place and method. His live-bait were large dace, and the yard of free tracing below the bullet gave them an opportunity of pirouetting in a pretty wide circle. The angler had fortunately "struck 'ile"; the eddy of his choice happened no doubt to be the furnished apartments into which a large family of pike had been driven by stress of water, and the bait had dropped into their midst like manna in the wilderness. Their pikeships one after another simply opened their jaws and absorbed the treacherous dace, without moving a foot, running madly when they found out the sort of man the angler was, but till then taking things ridiculously easy. In one lucky hour-I saw the fish, beantifully shaped and 
marked, spread out on a tray, and heard the story from the sportsman's own lips-the gentleman took six fish, the largest being I $3 \frac{1}{2}$ lb., rolb., and glb.-total $40 \mathrm{lb}$.

There is a well-known lake near Luton where it is not unusual for two rods to take a couple of hundredweight of pike averaging seven pounds in a day. In an angling club room in Shoreditch there is preserved the produce of one gentleman's rod in a single day. On reaching a nobleman's park in Kent he found the lake he was privileged to fish frozen, with the exception of one small sheltered corner, and more for the sake of not plodding back through the snow without a trial than from any expectation of sport he here threw in a live bait. Before he left the lake he had taken fish of the following weights:-28lb., I8lb. I40z., 9lb. 50z., 8lb. 90z., and 5lb. 50z.; and five splendid fish they are even in their stuffed state.

Pike may be caught in summer time with a gigantic and gaudy fly worked like a salmon fly about two inches below the surface. With a pliable spinning rod, and a water in which aquatic vegetation flourishes, some business-like execution may be wrought in August or, if hot, in September, by this plan. Fishing for pike with frog has gone out of fashion I fancy of late years, but it is a killing process, rightly managed.

A small perch with its dorsal fin cut off makes a good and tough spinning bait. Pike in their natural condition of life give the perch as wide a berth as possible. I once took a half digested perch, nevertheless, out of a pike's stomach; mentioning which circumstance to an old fisherman he described to me how once he had watched a pike pursue a perch, which thrust its head into the bank, put up its bristles, 
and by its every attitude plainly said "Catch me if you can." The pike remained fixed pointer-like for a few, minutes, and then slowly punted himself into the middle.

Pike may be eaten baked with veal stuffing, boiled with melted butter or, best of all, stuffed and roasted with strips of bacon tied round its shoulders, and basted to a fine pale brown colour. 


\section{CHAPTER IX.}

\section{FRESH AND SALT.}

"Night cąme, and now eight bells had rung,

While careless sailors, ever clieery,

On the mid-watch so jovial sung,

With tempers labour cannot weary."

THE great advantage of sojourning near the sea-shore is that if fresh water fails, you have plenty of salt close at hand. Fresh-water fish may, and too frequently do, take offence at adverse winds, and lose their tempers and become blind because of a little clouded water; your salt-water denizens, on the contrary, are above (below perhaps I ought to say) such trifling considerations as atmospheric changes and an odd storm or two in the upper air.

The Norfolk Broads when they do yield sport do so in no stinted measure; they bless you in basket and store. But they are uncertain as the idle wind which you respect not. The rivers Waveney and Yare contain roach, eels, and pike, with cartloads of bream in the summer, but they, too, are unusually capricious in their behaviour.

After some days of paltry sport, do not blame me if I tire of the district and everything associated with it. I have had a turn at three of the fourteen Broads a few miles inland from the Norfolk coast; have pulled through the watery lanes bounded by walls of bulrush and sedge, and tried my hardest under the blazing sun in the open water; have 
fumed and fretted, and have been only comforted with the reflection that the liggering parties whom I had seen drinking bottled beer, and singing songs on the water, had not caught a fish between a score of them. Perhaps if I had gone to Buckenham or Cantley it might have turned out differently, for on my return to town a friend compared notes with me, and I learned that on these very days he caught four pounds short of a hundred weight of roach at the former place, where the tide flows faintly and where the fish happened to be on the feed.

"Patience that lasts three days," think I, looking out at eventide upon Yarmouth market-place, "has a right to get rusty at last ; and to-morrow, behold ! I pack up my effects and flee on the wings of the morning."

Then it was that there flashed into my despondent mind the grand discovery recorded in the first sentence of this chapter; then it was I started forthwith to Gorleston to hold conference with a good motherly matron who owned a good fatherly husband, who, in his turn, owned a good weatherly fishing vessel ; and thus it was that I spent a night with the Herring Fleet, to give the salt water an opportunity of courteously recompensing me for the deceptions and coquetry of the rivers and Broads.

"You'll find it rough accommodation on board the Seabird, sir, but we'll make you as comfortable as we can," I am told next morning on appearing alongside, according to arrangement.

And what more can I expect? Beggars, says the proverb, are not precisely in the position of choosers, and I have begged from the owner of the Seabird the privilege of a passage during one of her herring-fishing excursions. The 
worthy owner was once sailor boy, sailor man, and skipper himself, and he is too close a stickler for the proprieties to grant the cheerful consent which trembles on his lips until he has obtained the ratifying approval of the Seabird's commander. It is not every shipmaster who will be pestered with a useless landlubber on his busy decks. But the captain of the Seabird with a broad smile speaks his welcome, and superadds the warning couched in the above remark.

The herring season is in full swing, for the middle of October has arrived, and in the splendidly furnished marketplace, which visitors to Yarmouth will well remember, the poulterers' stalls are laden with Michaelmas geese. Huge baskets of ripe blackberries are also exposed for sale, and pyramids of delicious outdoor grapes add their testimony to the lateness of the season. Should other witnesses be required, you may find them on the bits of cardboard in the lodging-house windows announcing empty apartments, and a consequent scarcity of visitors. When these signs and tokens appear, you may be sure the herring season is in full swing. While the undoubted summer lasts, Yarmouth is one of the most popular resorts of middle-class London, but about the period when "the hunter's moon" begins, the visitors smell the east wind and take flight. Then, about the second week in September, the herring boats are ready for the great harvest of the sea, which is expected to last till the end of November.

The Seabird, therefore, has already seen a month's active service. There she lies in the turbid tidal river which gives Yarmouth its name, resting awhile that her crew may enjoy a few hours' respite. Yesterday she came in with a cargo of fish; to-day she is moored idle in the bend of the river, 
within gunshot of Gorleston Pier; to-morrow she will again spread her wings of dusky canvas and make sail for the fishing-ground in yonder offing. Her little flag- $a$ white square on a ground of scarlet-flutters jauntily on the mizen-truck. The aft companionway, the hold, and the forecastle, are fastened down with padlock, and no careful watch patrols the black, solidly-patched, service-worn deck. Truly the skipper indulges in no mere affectation when he suggests that the Seabird is not exactly a floating palace.

To-morrow comes with the brightest of sunshine and the most musical of Sabbath bells. The crew arrive in twos and threes, swinging themselves down upon the damp decks, and if one or two lads seem to be suffering from that common malady in these parts $\_$a Saturday night on shore-there is, let it be charitably said, little wonder. For three weeks until yesterday the Seabird was hard at work outside of the harbour, and it would be expecting too much from human nature, especially human nature in a sailor's guernsey, to demand that the strapping young able-bodied fellows, who are as yet not half awake, should not make the most of their very brief holiday after the manner of their kind.

At length here we are on board-skipper, mate, cook, crew, and cabin-boy, eleven souls, with a stranger on what we may term the quarterdeck to make the complement a dozen, all told. The Hams and Peggottys of the village lounging on the quay above our heads make facetious remarks to the Seabird's crew touching their "first-class passenger," who somehow manages to survive these trials, and keeps close to the skipper at the helm, while the crew, with a lusty "Heave-ho!" chorus, warp the Seabird out, and run up the big mainsail and jib. 
Favoured by wind and tide the Seabird, in a few minutes, has ploughed through the yellow flood past Gorleston pierhead and is cleaving blue water, crushing, as it were, millions of diamonds out of her sun-gilded track as she goes. The church bells make fainter and fainter melody, the low shore land becomes lower, the people and buildings on the beach dwindle, dwarf, and fade. It is an old-fashioned iron handle which the skipper at the helm grasps, and this suggests inspection, which reveals that the Seabird herself, if not old-fashioned, may without defamation of character be described as a homely sort of craft. The Yarmouth herring fleet may have more comely vessels, but not many of heavier tonnage than the Seabird. She was once a smack, but has been latterly converted into a "Dandy," that is to say a yawl-rigged concern of some five-and-twenty tons. Is a rule the Yarmouth herring boats are lugger rigged, and the largest are not more than five-and-thirty tons. .

It is a day of peace on land, but these east coast toilers of the sea, I soon discover, are wroth with a keen grievance. What is uppermost in the mind will speedily be proclaimed by the tongue, and the sight of a small half-decked fishing boat, of not a third our size, inflames the more inflammable of our men. The grievance is, broadly stated, the presence of Scotch fishermen in Yarmouth and Lowestoft waters, and very bitter are the feelings of the English on the point. This is a Scotch boat making for land, and as she passes us within half a cable's length, our young men discharge a broadside of jeers and taunts at her handful of men. "Pretty fellows these Scots to brag that they never profane the Sabbath by handling rope on that day, and yet to be skulking about like this," shouts one. "They can live upon barley-meal without 
a morsel of meat from week-end to week-end, can these miserable Sawnies," quoth another. The cabin-boy facetiously rubs himself against the capstan-head and blesses the Duke of Argyle; the cook-unkindest curt of allflourishes aloft the leg of pork he is preparing in the caboose. To these demonstrations of derision the Scots answer never a word, but keep on their way to the river's mouth.

Unfortunately, the crew of the Seabird in this matter but represent the whole of their brethren of the east coast, and during a week's stay in the Yarmouth district 'I find a collision between English and Scotch fishermen every day probable. But the strangers have a perfect right to compete with the Norfolk men in their own waters, and the knowledge of this adds bitterness to the feelings with which the local fishermen find the market glutted and prices lowered by men who come in considerable numbers from a distance. The truth is the Scotchmen's mode of fishing answers too well for the taste of Yarmouth and Lowestoft. Their canny principle is small profits and quick returns. While the local luggers remain in the offing for two or three days the Scotchmen run in with their fish every morning and keep the fresh herring market supplied, sometimes overmuch. Hence the complaints of low prices heard this year on every hand. I suspect too the Scots work more economically than their English brethren. They are saved the expense of salt, and their small handy half-decked boats and lighter style of fishing require fewer men. Finally the North Britons are careful souls, whose fare is as frugal as their perseverance is incessant. Hence it comes about that though Christmas might bring good.will, let us hope, to the majority of man- 
kind, it will find bad blood between these rival herring fishermen.

So much I gather for later confirmation, while the Seabird increases the distance from land; and the men and boys, as they coil their ropes, and put things ship-shape, dwell upon their grievance, and nurse it to keep it warm. The mate has a cluster of unoccupied fishermen around him, and reads something which evidently absorbs their attention. It is the account in a local paper of an actual disturbance at Lowestoft in which a party of Scotchmen had allowed themselves to be drawn into a dispute - a dilemma they generally avoid with scrupulous caution. By-and-by loud laughter convulses the little auditory; this follows the reading of a police paragraph narrating how a fisher-boy had been summoned by an owner for remaining ashore. The evidence showed that the lad had poisoned his hand with a fish and was really unable to fulfil his contract, whereupon the presiding magistrate had said-

"In this case, willing as the Bench always is to protect the owiners, we must dismiss the summons."

It is the idea (right or wrong) that the Bench could ever dream of doing otherwise than "pertect the owners" that prompts the sarcastic mirth of the Seabird's merry men.

Our skipper is a fair-complexioned man. You often meet with this blonde type of men and women on the Yarmouth coast, inclining you to lend, a serious ear to the disputed tradition which teaches that Cerdic the warrior, or some other antique Saxon, settled here and planted a race with hair as yellow as the sands upon which they landed. Our skipper is a Saxon in every feature, and he stands beside the helm ; but, unlike the gentleman who occupied the same posi- 
tion on board the schooner Hesperus, his mouth is pipeless, smoking being unentered upon his list of small vices. He goodhumouredly listens to his subjects as they growl about the Scotchmen, smiles, I fear approvingly, and with a cheery hail gives the order-

"Now, my lads, bend nets. Look alive, bo'!"

The latter adjuration is for the cabin boy, who is dreamily employed in washing a tub full of potatoes for the mid-day meal, and whose occasional glances towards the dim line of coast the watchful skipper has noticed. The " Bo"," a palefaced, silent youth, who confides to me that he doesn't like the sea, grins in a melancholy manner, and looks alive as directed.

Bending the nets is an initiatory operation which must not be omitted. The bulk of the nets are neatly stowed away in the hold, but here lies a pile of recently repaired articles that must be tied together with strong twine. The patriarch of the crew, acting, as storekeeper, assists the mate in cutting the fastenings into requisite lengths, another man passes them on to the tyers, and another clears away the work when it is done. Thus early the orderly method by which alone herring fishing can be prosecuted becomes apparent, and everything forthwith goes on with a precision and discipline which, from the rude appointments of the boat and the rough-and-ready manner of the crew, you would not have considered probable.

Away on the starboard bow some one descries an object in the water-a cask, perhaps, or a chest. Our world, you must observe, is very limited in its area, and it is astonishing what importance trifles assume in it. We become quite excited as the skipper luffs up and steers for the prize, while 
all rush to the windward bulwarks and lean over the rail with undisguised interest. It is only a small rough box, but it is fished carefully up,.and for the space of half an hour all the probabilities which human ingenuity could suggest as to the origin and history of this bit of woodwork are advanced. Talk about an "exhaustive debate," you should have heard the crew of the Seabird before they had dismissed this sixpennyworth of white deal from their hands and minds.

About the hour when the people on shore are walking home from their churches and chapels the Seabird has reached the fishingground, and has taken her station as one of a very numerous family. The sun has become obscured, the sea rises with the wind, and the skipper prophesies "a breeze." To the crew this is a matter of positive indifference. They must remain here until a certain quantity of herrings are in the hold-it may be one day, it may be three-but the weather is a consideration which never troubles them. Since the sun was beclouded we can see nothing of land, but ships of all sizes are continually passing, proceeding up or down with an adverse wind.

The Seabird, it appears, will drive with the tide all night, and I make apparently careless, but really anxious, inquiries with the view of ascertaining what the chances are of being "collided." Are herring boats ever run down? Oh, yes, run down sometimes. A lugger, for example, was cut in two last year-no, the year before-and seven out of eight men went to " the locker." This is the way in which death by drowning is spoken of-very familiar, it struck me, as well as slightly disrespectful to the Dary Jones commonly associated with the metaphor.

The person who was facetiously described by the shorelings 
as the "first-class passenger" soon makes a disagreeable discovery. Deeming himself a very good sailor, he has gone to some trouble to enter upon this expedition; solely in the expectation, however, of being perpetually under sail. Movement is life. Movement on the sea, so long as it is decidedly progressive, is life in a not unpleasant form. Now I hear the order given to take in sail, and am informed that for the next twelve or eighteen hours the Seabird will drift with the flood-perhaps a dozen miles north and then a dozen miles back again; but always and entirely at the mercy of the waves.

Verily circumstances alter cases. The billows which, while we were careering seawards with a stiff breeze on the beam, dashed over the bows, were welcome and delicious to the Seabird; and to the passenger who, having nothing else to do, was able to enjoy the motion. To be tossed like a balk of timber on the said billows, and yet be like the caged squirrel whose perpetual wanderings never raise him an inch higher, is a vastly different thing. Yet this is the prospect; and I find out, when too late, that the trawler, and not the herring boat, should have been the object of my wooing. However, there is no help for it; out here there is no shore boat to hail.

The small sails are taken in, and the topmast struck. The mainsail follows, and, as if to remove all hope, the mainmast is lowered backwards, as the river steamers lower their funnels when passing under a bridge. The spar drops into a crutch upheld by a stout piece of timber about twelve feet long, fitted into the deck, somewhere about the centre of the vessel. Brought for the moment broadside to the waves, the Seabird wallows and rolls furiously and helplessly, 
until she is, by the small sail on the mizenmast, brought up to the wind. The rolling then ceases, but there supervenes a very lively game of pitch and toss, which threatens to become livelier as time wears on. This, then, is to be our condition for the night; and the only comfort we can snatch is that there are fully half a hundred boats in similar plight within ken, looking for all the world like disabled craft whose spars have been carried away in a hurricane. The Seabird is now technically "driving "; the movement, if any, being astern.

Mugs of hot tea, solid ship's biscuit, and, when called for by an epicurean member of the crew, a herring fried very brown to cover it, having been handed round, the word is given to "shoot nets." Every member of the crew but the cook and cabin boy engages in this work, which requires care and occupies considerable time. The dark brown nets lie stowed away in the hold, and the first work is to bring them to light.

It will simplify the description to explain at once that the drift net is nothing more than a wall of netting extending from the bows of the boat to a distance of about two miles, sunk by means of a cable nine or ten yards deep, and kept near the surface by small kegs called "bowls" and by a plentiful employment of large corks along the upper part of the net. The herrings swim in shoals, run their unsuspecting heads into the net wall, and become entangled in the meshes. This, however, is anticipating. The nets, or to be strictly accurate, the series of nets, tied together in an unbroken length as before explained, are not yet shot.

The skipper and three " hands" receive the nets, which 
glide freely over a roller from the hold; a lad takes up the "seizing," a short length of rope attached to every thirty yards of net, and walks with it to the bows, delivering it to a man who is paying out the stout cable, which, in addition to its function of keeping the bottom line of the nets fairly sunk, sustains the frail fabric as a connected whole. Sometimes vessels passing across the line of nets tear them asunder, and but for the cable the dissevered portionperhaps a mile in length - would be destroyed. A trusty man is therefore placed in the bows to affix the seizing to the cable with thoroughness.

As the Seabird drives astern and the shooting proceeds the bowls ride ahead of us like huge black floats, growing smaller and smaller until they are mere spots on the wave. Already, before the nets are fully shot, three brigs, a French fishing smack, and a barque reaching over towards land, pass across our line, doing more or less damage, one may be sure. The process of shooting keeps all hands in action for a couple of hours, and then, sitting as best they may on deck, with a service that gives little trouble and appetites that require no caviare, the men dine. Potatoes (such red kidneys the mate, who had grown them in his garden, swears never were before) cooked in their jackets, a grand leg of pork boiled to a turn, pudding, alias "duff," biscuit hard and wholesome, and a petit verre of highly perfumed Jamaica rum, constitute the sole bill of fare. Each man is his own carver, waiter, toastmaster, and speechmaker, and the music of the spheres leaves nothing to be desired in the way of orchestral accompaniment.

"Nightfall on the sea" is not a bad notion for a warm drawing-room, brightly lighted, and with the soft presence 
of women to give savour to the salt of home. I could in this paragraph draw a vivid portrait of a being who watches the footsteps of nightfall one after another upon the water on a Sunday evening about four-and-twenty miles east of Yarmouth, with a dismal sense of the falsity of poetical pictures of things pertaining to the maritime profession. He sits shivering and ill at ease, overcome by qualms with which conscience has nothing to do; a limp object on a sail behind the tiller handle, feebly noticing that the bow of the vessel is sometimes high in the air and the next moment down at the end of a slippery incline. Through his heavy head scraps of sea balladry are blown like flakes of foam by the blast. He vows never again to perpetuate the heresy contained in the fiction," "Rock'd in the cradle of the deep." He scoffs at the bard who found something to sing about in " the odour of brine from the ocean." He grins with ghastly expression when, noticing the lowered mainmast, the pretty words, "he climbs the mast to feast his eyes once more," are shaken uppermost. He is especially hurt to think that even the oblivion of actual sea-sickness is denied him. Such a sketch I might limn for the amusement of the callous; but I forbear.

The herrings have not behaved as we had fondly hoped. At eight o'clock a few fathoms of our two miles of net wall are hauled in, just as the moon struggles out of a bank of clouds, but there is no encouragement to proceed further. Then the men disappear down the aperture of two feet square into the small dark closet around which their berths are hidden. The skipper, kind and thoughtful as a mother to his "first-class passenger," insists upon offering him the use of his bunk, and spreads him a brand new Union Jack 
for blanket. On deck the two lights prescribed by law have been hoisted on the mizen-stay, and the watch has been set. The two lanterns are a signal to trawlers and passing vessels that the herring fishermen are out, and would prefer the gift of a wide berth, lest their nets should be broken. The sea seems alive with double warnings, and from some of the boats turpentine lights-yclept "flare ups"-are perpetually flashed.

Pitching and driving, you feel a queer sensation when a full-rigged ship, phantom-like, seems to be bearing down upon you, and somehow all the stories of collision you have heard, read, or written, crowd in procession through your mind, as you earnestly keep your eye on the approaching monster, resolving, should the worst come to the worst, to hoist yourself on board the destroyer by the bowsprit rigging. The monster passes half a mile ahead; but only think what might have happened. Think of the Northfleet ! And so on.

The fishermen sailors sleep in their clothes, and are contented with their lot. Theirs is a co-operative system; they are paid by results. The more fish the more pay. Called up on deck at twelve, and again at two o'clock, they rub their eyes and go, and return again if they are not immediately wanted. At four o'clock, however, a genuine cry rings down into the darkness.

"Haul ho, boys! Haul ho!"

Now we turn out in earnest, for "Haul ho!" means herrings, and who knows but that it may mean herrings in such quantities that to-morrow, instead of pitching and driving tediously, we may be able to hurry to harbour? The men encase themselves from head to foot in oilskin, 
and in the cold starlight prepare to haul in their two miles of netting.

The cable, or warp as the men term it, is brought in by the capstan worked in the old-fashioned manner with bars. Some of the Boulogne boats have small steam-engines to do this work, which requires the incessant labour of four or five hands until the hauling is at an end. To the landlubber prone upon the flag of his country in the skipper's bunk, the tramp, tramp of the men on their ceaseless round is as the march of an army, and it is their preliminary circuits that have recalled him from an uneasy dreamland, and brought him into the keen morning air to watch his shipmates deal with the herring. Two men stand about six feet apart in the middle of the boat on the starboard side to haul the net upon deck. At the bow the sailor who was perched there in the afternoon is perched there again to unfasten the seizings he had then tied to the warp.

A man takes his post in the hold to stow away into the smallest compass, and in regular layers, the nets with bowls attached. The other men are "scudders," which, being interpreted, signifies that they seize the net as it is passed over the bulwarks, and by violently shaking it, jerk the fish out of the meshes. In a little while we are all speckled with scales, like harlequins in silver mail ; there are scales everywhere, high and low; scales in your beard and scales in your pocket-ay, in the tobacco-pouch in your pocket.

Thus the herrings are scudded on the deck for the space of five hours, and when the neighbourhood is too much cumbered with fish, they are shovelled into a separate part of the hold through holes formed for the purpose. The fish are mostly exhausted from their struggles to be released from 
the net, and many of them never move after they are shaken from the toils. Others, on the contrary, leap about the deck vigorously; but it is soon over. The proverb "dead as a herring" seems to cast a reflection upon the vital powers of this little fish, and there is ground for it. Herrings speedily yield up the ghost when taken out of the water. They are most exquisitely tinted at first with a hue of faint rose-pink, but the mere contact of one herring with another is enough to strip it of its beautiful vesture. The majority are caught by the gills; a few, I notice, have thrust themselves more than a third of their length through the mesh, and they retain the impression of the cord in a girdle cut round the body, though it does not fracture the skin. The position of the bulk of the fish on one side of the net shows which way the shoal moved, and the common direction they took. A few now and then have been captured while swimming from an opposite quarter, waifs and strays probably. Here comes a cod caught somehow in the gills, and already drowned; for him and his kindred a long-handled landing net is kept near. From first to last the nets bring up a dozen mackerel and half as many whiting.

The other boats near us are hauling in concert, and over the line of nets of a lugger that two days later, alas! is doomed to founder in the tempest, whose vanguard gusts are sweeping the Seabird's decks, a horde of buccaneer fowl, gannets, gulls, and what not, are hovering, dragging the nets out of water, and robbing the fishermen of their hardly won spoil. The sun rises on the sails of many of the herring fleet homeward bound. Some of them have been driving out here for two or three days, and are returning with fewer fish than have fallen to our share in one night. It is still 
undecided whether the Seabird shall take flight or linger through another day and night. There is nothing to complain of in the "take," but every man and boy can remember when, in very exceptional hauls, ten times the quantity have been taken. Not this year, however. They all agree that the good old times have gone, and that the herrings are neither so numerous nor so prime as they used to be. Several boats are mentioned, while the herrings are being shaken out of the nets and the scales are discharged around in volleys, which have earned hundreds of pounds less than in the previous year.

After five hours of hard work the last bowl is seen tossing on the crest of the waves and disappearing in the troughs; the skipper takes the hatch from the well in which the fish are stored, pronounces the haul to be "a last"nominally 10,000 , but actually I 3,200 fish--and laconically orders the crew to make preparations for getting under weigh. A wise skipper this! Instead of smothering his dainty herrings with salt, as many of his compeers are doing, and staying for another chance, he determines to hie for port and save the fresh herring market.

A rude, laborious life my comrades of the Seabird must have. In all weathers, and for nine months in the year, they pursue the double avocations of sailor and fisherman ; frshermen first, perhaps, and sailors afterwards. At times a gale suddenly rises before the hauling begins, and it is a point of honour with the east coast fishermen never to forsake the nets. They make everything snug, and so long as the craft can be kept head to wind they ride out the storm, buffeted and tossed, while we at our firesides little wot of their hardships and perils. The herring season over, the Seabird, for 
example, becomes a trawler, and scours the North Sea in the teeth of the winter weather. Every available inch of space below decks is required for stowage, and there is scarcely room for comfort. The trawlers remain on their distant fishing grounds for weeks together, fast cutters visiting them daily to convey the fish to shore ; and many a fisherman is washed overboard during the transfer of the fish to the carrier smack.

The Seabird has heels this morning as she heads for land. Each added sail causes her to throb with delight; the crew, after their long spell of toil, are light-hearted too, and even the forlorn object who sat on the sail abaft the tiller handle last night shares in the prevailing gaiety. "Homeward bound" after all is a better tune than "Nightfall on the sea." There must be no stoppage till the Seabird ranges alongside Yarmouth fish wharf; the herrings must be sold at Billingsgate before the town is fairly astir to-morrow morning, and the Seabird to-night must once more shoot her nets a score of miles at sea. At the mouth of the river a tug answers our signal; takes two other new arrivals in tow, and drags us with a rush past Gorleston on the one side and South Denes on the other, to the wharf.

Here the well-known scenes are repeated. The fish are taken away in "swills," placed on the wharf, and sold by auction. The market is somewhat glutted to-day, and it is only after a remonstrance from the salesman that the herrings are disposed of at five guineas per last. Prices are very fluctuating in this bustling market ; in the early part of the season when fish were scarce a small cargo was sold at $£ 40$ the last; not many weeks since it was impossible to coax the buyers into giving more than $£^{2}{ }^{5}$ s. Only this 
morning the first-comers obtained as much as $£$ io per last.

The Seabird, with her genial skipper and jolly crew, having. had the last herring emptied into the "swill," is tugged out into the stream, and from the pier where the boys are hauling up small codlings and whiting, an hour or two before sunset I can spy afar off the little flag with a white centre and red ground voyaging in company with other boats, two at least of which will nevermore return to land.

Practical Notes on the Norfolk Broads.

These notes I will endeavour to invest with all the value of a lady's postscript, in order to make amends for any unkind thoughts into which I have been, by ill-luck, betrayed against the East Anglian Broads. Taken at the proper time these singular sheets of water brim over with coarse sport to the angler; I say taken at the proper time, because unless this proviso be considered it will be waste labour indeed to visit them. Thus, you hear wondrous stories of bream capture, yet take no note of the month when it happened. The stories referred to July, and you are disgusted because in October you fail to prick a fish. The same experience will be yours if you try for pike before winter. There is a time for all things, good reader, and the time for bream in the Norfolk Broads is July and August, and as much of September as the sun vouchsafes to you; while the time for jack is-December good, January better, February best.

How many Broads there may be in Suffolk and Norfolk I am not prepared to say, but with a map spread out before 
me I once ticked off four-and-twenty without having exhausted the two counties. The largest Broads are Surlingham, Rockland, Breydon, Filby, Ormesby, Rollesby, Hickling, Barton, Irstead, .and Wroxham. I have spent pleasant days at Ormesby, where you are quite out of the pale of civilisation. Attached to the little inn there is a rare old-fashioned flower garden and a pretty approach to the lake; generally, however, the scenery of the Broads partakes of the flatness, and therefore prosiness of the county. Fritton decoy, in another direction, is the most picturesque piece of water, almost entirely surrounded by lofty trees; the water is unpleasant, being of a greenish. tinge, by which reason the fish, though numerous, are flabby and uninviting. One afternoon a party of three of us were perpetually pestered by small eels and popes until the nuisance was beyond bearing. The eels spoiled our tackle and desecrated the seats of the boat; the ruffs came up with their goggle eyes, veritable goblins from the vasty deep, and between them they beat us off the field.

Take your own tackle when you go into Norfolk, and scoured baits also. At the Broads (I was on the point of writing broad sides) the gardeners or servant boys will give you buckets full of meal and brewers' grains for ground bait, and when the crops do not claim their first care, you may obtain the services of a rower. The latter, except for pike-fishing, is a superfluity, inasmuch as you bring up your boat at given pitches-generally beds of bulrushand remain there. Plain homely meat and drink will be your fare at the modest hostelries, bushel baskets will be lent you for the fish, and the native innkeepers have not yet learnt the fashionable art of extortion. 
Many of the Broads, all the best ones indeed, are, though private property, accessible to a decent sportsman. Bream, pike, and perch are still their most numerous fish; the roach, as might be expected, are vastly inferior to their brethren of even such muddy rivers as you find at Reedham, Cantley, and Buckenham. In one of the Norwich tackleshops I saw a stuffed bream of $9 \frac{1}{4} \mathrm{lb}$., the largest I ever heard of; in a Yarmouth public-house I caught sight, through the open door, of a brace of pike in a glass case, each of which had turned the scale at three-and-twenty pounds when taken from the Broads. The stranger will act wisely if he make inquiries of some practical person-there are many such in Yarmouth, Norwich, and Lowestoft, the three centres from which the Broads must be "tapped"before setting forth upon his'expedition.

If you are fond of ornithology as a science, or wild-fowl as an object of sport, the Norfolk and Suffolk Broads offer a fruitful field of exploration. There are snipe on the marshes, widgeon, teal, coot, duck, and geese in their season; the heron revels upon the flat oozy shores, the reedsparrow twitters in the sedges, and if there are any bitterns left in the land here they will be.

As for eels the countrymen would not think of tying less than thirty or forty hooks baited with small fish on their night-lines, and are to their notion scurvily used by Dame Fortune if more than a third of that number are non-productive. The bottoms of the Broads with one or two exceptions are muddy - the very ground for an eel; the exceptions are due to gravel, and Hickling Broad, I believe, is one of them.

These Broads are largely used by holiday parties in the 


\section{FRESH AND SALT.}

summer months; the experienced sportsman has no business there with rod and gun till winter, and even then he will be fortunate if he can realise anything like the glowing accounts given of bygone years: 


\section{CHAPTER X.}

\section{HOOKED FOUL.}

"Give me mine angle. We'll to the river; there My music playing far off, I will betray

Tawny finn'd fishes; my bended hook shall pierce Their shining jaws."

IT was an unmistakably blank day yonder for the entire company, as somehow it always happens to be when you expect unusual luck, and have every reason for believing it will fall to your lot.

"Come early," the young Squire wrote; "the stream is alive with trout, the c'rect fly is on, and there's something prime in the cellar, to say nothing of duck and green peas at the back of the stables. Further, the wife says you are to come, and that should settle it; I suppose you had better bring $\mathrm{B}-$, though he scarcely knows a fish from a fiddle, and must be handed over to the women-folk."

We accordingly went, and B-C, I must say, had the laugh of us. A bitter east wind set in within an hour of our arrival at the Squire's place, and early in the afternoon we gave up angling, nor entertained so much as a forlorn hope of evening chances. We stuck the rods into the lawn, and formed ourselves into a select committee to inquire into the uses of hock and seltzer. The young Squire also told us a little story. 
"Some prefer one method and some another," he said to me ; "but for real honest sport-yielding pike-fishing, depend upon it there is nothing like a neat spinning-flight.

"Come, come; don't shrug your shoulders!" he observed to the prosaic $\mathrm{B} \longrightarrow$ - who had resigned himself to the infliction without concealing his feelings.

"I know too well how terrible a bore an angler is to an unsympathetic town man like you, who have not a soul above a brief-bag, and who would not know a gudgeon from a barbel. Bless you! I should disdain to waste a delicious story of rises, runs, bites, strikes, and gaffings, upon the like of you. My pearls are reserved for those who will not turn about and rend me. Still, as you are in my den, and as you have been kind enough to notice my rod-rack, and the rest of my fishing gear yonder-which you may notice is in apple-pie order, ready for immediate use-I will trouble you to listen to one reason of my partiality for the spinningflight.

"Let me see, it was-Ah! never mind when it happened. It was not this year, nor last, nor the year before that. Enough that I begin with a certain fresh autumn morning. The crunch of the dogcart wheels on the gravel beneath my bed-room window reminded me that I had overslept myself, and that there would be some one outside cooling his heels, unless he was much altered since I had seen him last, in anything but a Christian frame of mind. My oversleeping was indulged in at the cost of considerable discomfort, inasmuch as when we had sped merrily over a couple of the ten miles before us, I discovered that neither gaff-hook nor landing net had been packed up.

"You call that a trifle do you? A trifle! But, of course, 
it is useless to argue with you. Out of such trifles great what-is-it's spring, if your favourite poet is to be believed.

"Garstanger Park is one of the most beautiful because one of the best timbered in the country. Had that October day on Viscount Garstanger's lake been a blank as to fish, I should have deemed the seventy-mile trip from town, the early rising on a raw morning, and the journey across country more than compensated for by the russet glory of the autumntinted woods, the exquisite proportions of the shrubberies, the artistic arrangement of lawn and garden, the wide prospects caught through the beeches on the knolls, the avenues of patriarch trees, the change of landscape at every curve of the path, and the keen clear atmosphere which you gulped rather than breathed.

"This kind of scenery puts you into good humour, and screws up any slack strings of poetry or sentiment there may be in you. It never took me so long before to put my rod together, partly because of the beautiful leaf-tints reflected in the lake, but chiefly because, making ready to enter one of the two punts which belonged to the boat-house, I saw a young lady. She might be handsome or she might not; that I could not determine until she changed her position. It was her compact, flexible figure, and peculiar costume, that first attracted my notice. I was conscious, too, of a freedom of attitude that under any other circumstances would have been displeasing. She stood some distance off, her back towards me, with one foot on the stern-board of the punt, and was postured like an athlete, as, turning slightly away from the lake, with rod over her shoulder, she winched up the loosened coils of a fishing-line.

"The boobiest of fellows lay in the bottom of the punt, 
reading one of Dumas' novels-a shilling edition. He never offered to assist his companion. I would have said 'fair' companion, according to the orthodox method, but I had not, so far, discovered whether she was fair or dark. The foot, so firmly planted on the punt, was the small trim foot which, as a rule, belongs to dark beauties; the hair, though dark, was not black, and it was free from any artificial monstrosity. Dress? I fear you have me there : never was there a worse describer of millinery than your humble servant. To put it roughly, I should say the chief article of that costume was a well-built shooting-jacket of grey cloth. It was of a perfectly original design, and impressed you as being fitted up with an infinity of pockets and enclosing with sensible tightness a charming, round, lithe figure. I forget the skirts, but they were there.

"It was no use coughing or making a violent noise with the oars strapped to our own punt: she would not look round, or satisfy my curiosity in any degree. The boobiest of fellows lazily looked across, lazily screwed his glass into his eye, and lazily made an observation to his companion, who, to do her justice, appeared not to take the slightest notice of him.

"Who were they? What were they? Which was the angler? I had, in former times, seen ladies fishing for the lively perch, ay, and whipping a dainty little stream with a dainty little fly-rod for dainty little trout, but the boldest of the lady anglers whom it had been my pleasure to know had certainly drawn a line at the 'mighty luce.'

"Doubtless this was a good-natured damsel, encouraging that boobiest of fellows in his abominable idleness, by arranging his tackle for him. He had kindled a cigar by 
the time she had finished the winching-up process, but he was in no hurry to move from his lair. He allowed her to deposit the rod in the punt, to step aboard without assistance, and, by all that was unworthy! to cast off the chain.

"A nut-brown maid she at last proved to be, and a very business-like maid, too, with eyes for nothing but the punt and the fishing materials. Briskly seating herself on the thwart, she took the oars in her gloved hands, and pulled out to the centre of the lake, the strokes regular, strong, and determined. Full well I could appreciate her skill, for a pretty figure my companion cut, in his ignorance of the management of our:flat-bottomed craft.

"Staring, and speechlessness, and wonderment did not aid one, as you may suppose. There happened to be no keepers about; the constant breech-loader reports in the distant plantations indicated their whereabouts with sufficient plainness. So, with curiosity unsatisfied, and much more absorbed and reluctant than is my wont with a sheet of well-preserved water, ruffled by a westerly breeze, at my will, I imitated the nut-brown maid, and pushed off, showing how much I was thinking of her by proceeding in a contrary direction to that she had taken, and inwardly resolving to sneak round about her neighbourhood before the day was over.

"Sport was, for a time, indifferent; that is to say, indifferent for Garstanger Park. A few three-pounders were returned to the water, an eight-pounder got away, and as. luncheon-time drew nigh, the bag contained only half a dozen fair fish. The fish, you see, so far as I was concerned, were finding an unknown friend in the nut-brown. maid. 
"The time had arrived when the mystery must be cleared up. My companion paddled me slowly to the upper end of the lake, I making a pretence of spinning the water as we progressed. A sudden bend of the shore gave us sight of the other punt. The boobiest of fellows still reclined at his ease, and my nut-brown maid stood confessed a veritable pike-mistress.

"What a figure, too, as she lightly swept the bamboo spinning-rod over her left shoulder, and brought it back again for the cast! It was the freest and most graceful I ever witnessed. The bait fell with a minimum of splash into the water, not an inch less than twenty yards the lee side of the punt, and it was spun home at a speed and depth that bespoke the experienced artist.

"You may laugh, my friend, but do you not speak of a singer, or dancer, or actor as an 'artiste'? Therefore, my signification of the term, your ribald jeer notwithstanding, is quite justifiable. The miserable jester who chuckles over the stale old senseless saying, ' $A$ fool at one end and a worm at the other,' will not, perhaps, understand me, but that large and increasing class of anglers, who are the product of nineteenth century refinement-yes, I do not withdraw the assertion - these will know how to admire my nymph of the rod. For the space of half an hour she made superb leisurely casts, taking the punt as a centre from which to make the radiations, beginning with a dozen yards, and regularly increasing the distance, until the maximum of twenty yards was reached.

"It was some comfort that she just now caught no fish. I felt so much the less ashamed of myself. A very good angler, according to the estimate of my friends, I confess 
I here found my master-my lady superior. Never an entanglement, never a false throw, never any trouble with rings or reel, never the faintest appearance of flurry was she guilty of. A toxophilite, of the feminine gender, in the act of discharging an arrow from the bow, a huntress 'lifting' her horse over a stiff fence, a girl bending to the oars on a silver stream, are fit subjects for any painter, but not worthy of comparison with my Angling Divinity of Garstanger Park.

"She answered the purpose, as it were, of a whirlpool to our boat; it began to draw insensibly into the vortex. We approached nearer and nearer. The boobiest of fellows maintained his masterly inactivity, turning over page after page of his buff-covered book, and allowing the nutbrown maid-when, having thoroughly fished her circle, she paddled to new ground-to handle the oars without a scrap of assistance from his long, white, useless fingers.

"Aha! she had him at last-not the supine novelreader-but a fish! For this I had been waiting. A lady who could spin for pike in this most mistressly style, I had for the first time beheld; but what would she do with it when the critical moment arrived? It was, as I might have known, of a piece with the rest. She handled the fresh-water shark with consummate skill: it ought to have been a pleasure to any well-regulated pike to be so scientifically dealt with. I could tell by the quick jerk of the rod that the deluded fish was a good one, and the sharp, prompt little twist of the lady's wrist was proof positive that the triangles had been well struck into him.

"Sensible woman! Yet it was so like her sex to permit the captive to bolt about wherever he listed, confident that 
he was secured, and not objecting to enjoy his hopeless struggles before treating him to the coup de grâce. The pike seemed particularly uncomfortable, and the lady smiled a smile of calm and virtuous content as he gave evidence of his perturbed state of mind. He kept well down into the deep, describing, as the line indicated, a series of strange mathematical figures.

"The moment the angleress tightened on him, he leaped, shining like gold, a foot out of the water!-bringing another quiet smile into her placid face when he fell back. Her theory was to give her enemy plenty of line-(and let me tell you in an 'aside,' there are worse notions than that for other pursuits than pike-fishing). The line was hauled in and neatly deposited in circles on the floor of the punt; and when, at length, the broad yellow side of the conquered one appeared on the surface at the exact spot necessary for successful bagging, the lady, with a slight flush of cheek and flash of eye, inserted the gaff under his gaping gill, and lifted him deftly over the gunwale.

"A cheery bell-metal laugh broke the silence. The game-objecting, maybe, to the morality of Mons. Dumas-flapped and floundered at the young gentleman in the stern, causing him to splutter, to drop 'Beau 'Tancrede,' and jump so ludicrously, that the nut-brown maid indulged in several merry peals.

"The fish could not frighten her: to be sure, petticoats are a protection to a lady in more ways than one. But she made no effort to get out of his way when he descended against her skirts; on the contrary, she waited her opportunity-thrust her fore-finger and thumb into the eye-sockets, 
honouring the fish by the act; and, unhooking the gimp to which the hooks were attached from the tracing-swivel, dropped his pikeship, with due regard to decency and preservation, into a large rush basket that, I suspect, had often done similar duty aforetime.

"The lady was uncommonly methodical, I noticed. In precisely the proper place for handiness, there was a tin case, stored with spinning tackle already baited, leaving her nothing to do at each capture but attach the loop to the swivel. This saved her the unpleasant necessity of meddling with the small dead fish employed as bait, and the much more unpleasant necessity of gouging the murderous triangles out of the pike's formidable jaws-labour I fain hoped fell to the share of some male relative at home.

"A complimentary sentence trembled at the tip of my tongue, but her appearance furnished me no encouragement to utter it. Besides, there was no time, since before resuming operations she gave her punt the benefit of half a dozen vigorous strokes of the oars, by which movement the few paces which had separated us were quadrupled; and, as. you must confess, it would have been simply ridiculous to make a speaking trumpet of your hand, and bawl at the top of your voice-

"'Allow me, madam,' or 'dear madam,' as the case might be, "to congratulate you upon the clever marner in which you killed that fish.'

"Absurd, would it not?

"My amateur boatman furthermore began to taunt me upon my idleness, my non-success, my moon-strucky behaviour. To taunt was to rouse. I (metaphorically) girded up my loins, and bade the fish to come on, that I 
might smite them hip and thigh with great slaughter. I invoked the aid of the late Izaak Walton, Esq., and hummed a bar or two of 'Doughty Deeds.' I so manœuvred thepunt that the nut-brown unknown should have me in view, to contrast my manly proportions, if haply she looked our way, with the lanky, flax-headed, insipid dawdler, whose general purpose in the economy of Nature, and particular business in that punt, were unsolved conundrums to me just then.

"Swish! whistle ! splash! spin! and at it I went. Heigho! What was this? A tree-trunk submerged? Bravo! . It was one of the mighty ones of the lake. Feeling the hooks. he went off, pulling like a barge. Twenty, forty, fifty, a hundred yards of line were run straight off the reel, without so much as a 'By your leave.' It was that peculiar run. by which a substantial prize is always known, be it salmon, trout, or pike ; none of your tug-tugs, dart-darts, here-thereand-everywhere up-and-down trifling, but a steady, heavy, sullen travelling away from the base of assault. The stricken fish headed straight for the bow of the other punt. My companion, taking his commands from me, backed water, and we followed. My lady had paused in her work, and stood, rod in hand, with a dark green belt of firs as a distant background, and the ruddy sun striking slantwise upon her, a model for a statue. She forgot the formal reserve of the lady, in the enthusiasm of the sportswoman.

" 'You have a fine fish there!' she ejaculated, quite as delighted as if it were her luck, and not mine.

“" 'Indeed yes,' I replied, beginning to strain upon the object in question ; 'but unfortunately I have no gaff.' “ 'Oh, take mine. Do you think I can help you ?' she said. 
"The fish was at that moment making a fresh spurt, and it hehoved me to be wary; but be the consequences what they might, I was bound to look into her face, and express my thanks with eye as well as lip. Well, never mind. There are obvious reasons why it would be better to say no more upon this part of the proceeding.

"As to the pike, there he is, stuffed and still in the lower case. Judge for yourself the fun we-I advisedly deem it a partnership matter-had before we made his personal acquaintance. We brought the punts close together, and before I knew her intentions, my newly made friend had stepped nimbly into my boat and was at my side, quietly biding the time to strike. I wished to transfer the rod to her, and take the gaffing upon myself; she pleaded hard to have the honcur, and I vow that if she had pleaded to gaff me, in licu of the fish, so charmingly did she piead, I would have interposed no objection.

"Half an hour fully were we privileged to stand side by side waiting for the end. To tell you the whole truth, I delayed the consummation till for very shame I had to present the butt of the rod to the fish; and even that would not have been ventured upon, but for a hint from the lady that the fish's extremity was my opportunity. Thereupon I closed with him, brought him to reaching distance, and enjoyed the felicity of beholding the sharp gaff unerringly employed, and the monster hauled, viciousiy plunging, out of his native element.

" ' $\mathrm{Ha}$ ! ha! hooked foul !' quoth the nut-brown maid, with a little dance of astonishment. It was even so; the fish was, as anglers put it, 'hooked foul.'

"Then up and spake the being in the other boat, who had 
been, I am well assured, forgotten by the entire company, while a nobler creature, albeit of the finny order, had engaged our attention. Probably he had been watching us out of the corner of his fishy-looking eye, though now he pretended languidly to put aside his book for the first time.

" "Did I underthtand, Tharah, that you thaid "Hooked foul ?" ' he drawled.

"She turned a trifle sharply towards him, as if recalled by the question into another and less pleasant state of being; so at least I flattered myself.

" 'I don't know what you understood, Frank, but that is what I said. It may not be grammar, but it is a perfectly well-known technical phrase. Yes ; I said "hooked foul," she boldly answered.

" "And will you tell me, Tharah, what ith "hooked foul?" "

“' Hooked foul, Frank,' she stated, without looking at her questioner, "means "hooked foul." That is to say you are trying to hook something in one way, fail to do so, but hook it in another not quite so straightforward. You don't get it by hook but by crook.'.

"This being not a very lucid explanation, I was emboldened to take up the parable. Said I, with an air of nonchalant wisdom-

" "You see, this fish, if caught in the orthodox way, would have snapped at the baited hooks, and enclosed them with his jaws. He probably went so far as the snap, and missed the bait, but the revolving hooks caught him on the shoulder, as you observe, and here he is. The great point, aftor all, is that he is hooked samehow.'

"'It's not a pleasant thing to be hooked foul, Frank,' 
observed the young lady who had been addressed as Sarah.

“' 'P'wapth not, Tharah,' he rejoined, with a greenish tinge in his eye; 'but, ath you thay, the great point ith that your fith ith hooked thomehow.'

"What possessed me, unless the thing called Fate, to take part in a dialogue which had most evidently assumed a meaning personal to the speakers, I know not, but I must needs fix my eye upon the young man, and observe-

" "Well, that depends on circumstances, you know. A fish hooked foul, you should remember, has a very good chance of shaking itself free.'

"This was but a random shot, but, like many another bow at a venture, it went home. The lisper changed to the colour of tallow, while the nut-brown maid's face was suddenly warmed from within by a crimson flush. However, the mischief was done, and we separated in constraint. The evening drew on apace, and at dusk we found ourselves together again at the lodge, weighing the prize.

"It was sunset. The woods were crowned with the golden glow of the west; the lady stood in the reflection, its queen. The boobiest of fellows sulked at the garden gate; we could afford to dispense with his company.

"It is best to be particular : that fish weighed twenty-nine pounds five ounces and one quarter, by the keeper's steelyard.

" 'A very fine fish, sir. Grood night,' the lady said.

“' 'Yes, very fine; good night,' I answered, doffing my deerstalker, of course ; the lout at the gate scowling covertly the while.

"And was that all ? What more would you wish? 
Simply a casual meeting, and an abrupt parting. What more would you have?

"Let me detain you another monent. There was something else. The nut-brown maid was a clergyman's daughter, Miss Graham by name. So much I found out by directly questioning the keeper. I drove out of Garstanger Park, sincerely wishing it had been my fortune to know more of her, debating whether the phase of strong-mindedness I had seen was a desirable symptom for a young lady and a clergyman's daughter, and altogether a little-the smallest bitin love with her.

"A month or two later came that German episode of mine, and the nut-brown maid, though not absolutely forgotten, was not a frequent or troublesome visitor at Memory's door. She used to knock at it in the quiet hours sometimes, and I would always open it, and admit and keep her there as long as possible. But I can conscientiously aver she was merely as the refrain of a dreamy melody floating from a distance. I was destined to be somewhat rudely reminded of her and hers on my return to England.

"Dozing in the big easy chair of my sitting-rnom one twilight, the tableau I described at the keeper's lodge came to me in a vision, in which the young man skulking at the gate seemed to change into the pike hanging from the steelyard. It may seem very like a storyteller's trick to say it, but I was awakened by a knocking at my door, and the young man himself pushed past the servant, and stalked into the room.

" 'Do you thee thith whip ?' he said, flourishing a heavythonged hunting weapon.

"' Thit down, young man,' I answered, mockingly, but 
mighty wrathful, you may be certain, at the outrage, the meaning of which was evident.

" 'Do you thee thith whip?' he shrieked, moving towards me, who had not yet risen from my dozing posture.

"It was an unfortunate occurrence. A week within a day elapsed before he could be removed into the country, and it cost me a lot of money for doctoring him, to say nothing of that possible verdict of 'manslaughter,' which haunted me morning, noon, and night. I must acknowledge, as he did afterwards, that the thrashing did him good; it made him penitent, and during the penitence a fit of communicativeness supervened.

"It appeared (as learned counsel say to juries) that he was a Graham too, a cousin of the young lady with the nut-brown face, and-but you already guess it-engaged to her almost from childhood, in accordance with the fond parents' desires. That they cordially hated each other, both the demands of truth and the requirements of fiction compel me to declare. Only, Harold Graham was not prepared to relinquish the hard cash which was to be his when he married his Cousin Sarah. The day at Garstanger Park was a crisis in their career. Mr. Graham thought fit, after the tableau at the lodge, to remonstrate with his affianced; first, for using the expression 'Hooked foul,' and next, for being what he impertinently characterised unwomanly in her amusements. While my friend and I were rattling through the lanes in happy content, that youthful couple were having, in vulgar parlance, quite a respectable row. Somehow I, the unknown stranger, was introduced into the quarrel, and Mademoiselle indiscreetly made comparisons. 
" ' The fact is,' she said, 'I don't forget what that young gentleman so sensibly remarked: "A fish hooked foul has a very good chance of shaking itself free." ,

"From that moment Sarah Graham devoted herself to the task of shaking herself free: she considered she was 'hooked foul.' From that moment Harold Graham gave himself up to revenge. There was one slight difficulty to be overcome, viz., his ignorance of my name, address, and station. It took him months to get over it. He spent a little fortune, they say, in journeys to London, hoping to meet me by accident. Finally he sought Lord Garstanger, and pretending I had lent him a flask, or winch, or cigarcase, or something which he wished to return, found out my whereabouts. $\mathrm{He}$ had, in some inconceivable manner, stumbled upon the notion that $I$ was in communication with his cousin, and that I was supplanting him. She herself rather encouraged the idea to spite him, and byand-by his hatred of me became a mania.

"Shall I detain you much longer? No. I have placed the ends of the skein in your hands : it is for you to gather them up. Harold Graham was a poor weak creature; he was never known to display energy before the interval between our day at Garstanger Park and the athletic exercise he and I took in my sitting-room, and since then he has subsided into a sort of amateur idiocy.

"And now you ask me whether I do not consider Sarah Graham a very objectionable young woman? In confidence, I assure you I do not. I take your vehement affirmation of a contrary opinion as a sign of profound insight into human character, my young friend. Don't be angry with me, if I suggest we should agree to differ. 
"But here's the good wife with the bairns to say 'good even! Let us ask her to decide between us.

"Does she know the story?

"Pretty well, I believe! Between ourselves, old fellow, she is the nut-brown maid!" 


\section{CHAPTER XI.}

\section{UNLUCKY DAYS IN WALES.}

"'Tis not in mortals to command success,

But we'll do more, Sempronius! We'll deserve it."

Amongst the full tale of unlucky days that have fallen to my share the three most unlucky were in the Principality. Number one was a February day on the Usk; number two a Whit-Monday on Lake Ogwen; and number three a halfholiday on Llangorst Pool.

When you are the fortunate holder of an invitation to fish a stream worth the fishing to an extent which makes the invitation equal in your eyes to its weight in gold, you naturally rejoice, and prepare to live up to your privileges. Placed in circumstances which make it doubtful whether such an opportunity will for many a long day again be offered, wind and weather are not likely to stand in your way. Yet, if there is anything more absolutely hopeless than the prospect of inducing a trout to look at a fly on a frosty morning, not five days beyond January, with ice on the puddles, and a thick garment of hoar upon the shoulders of the mountains, I should like to hear what that prospect is. The opening of my February day on the Usk was enough to make one exclaim with cynical Byron :-

$$
\text { "No-as soon }
$$

Seek roses in December, ice in June ; 
Hope constancy in wind, or corn in chaff;

Believe a woman, or an epitaph ;"

-as hope to deprive a trout of life on such an objectionable fishing day as it in every respect was.

But if only for the fun of the attempt we resolved to make the best of the inevitable, and, donning our warmest ulsters, departed on our eight mile drive to the river. Cowper indited a quantity of interesting lines on "A Winter's Walk at Noon"; had I a Cowper's muse I might have sung the charms of "A Winter's Ride at Morn." Not that the captain, my genial host and companion, was of a poetical turn of mind; but he could handle the reins, and also the whip, with the reservation that long familiarity with the fly rod led him to impart an involuntary whipping motion to the weapon, and make everlasting casts at the chestnut's ear. The captain was not poetical, probably because it is not a way they have in the army, but he had a poet's love for the beautiful, and uttered many neat remarks in praise of the mountains along whose side we journeyed.

Wales is rich in valleys, and that which lay beneath us was perfect in all the features that should compose a clearly defined vale. Never exceeding a mile in width, never too narrow to obstruct the view, it stretched across from one range of hills to another, level as a lawn, and brightly green. Down the middle flowed a trout stream ; farms and cottages, like decorations on a courtier's bosom, shone in the strengthening sun. It' wound about under the hills enough to give repeated changes of landscape, yet not abruptly to spoil the gracefulness of the general idea, which was that of a succession of sweeping vistas, leading to something still more beautuful beyond. In the distance bolder summits than 
any immediately overshadowing the valley lifted their brows, wrinkling with fantastic rapidity as the sunbeams smote the frost and thawed the whiteness. Nearer at hand we had in. cipient furze blossoms and hedges heavy with glittering hoar.

The keeper was waiting for his young master, with a question in his eye which it was unnecessary to translate into words. "Oh yes, we'll try certainly, as we have come so far," answered the captain, divining his thoughts, "but there is not the ghost of a chance."

"'Deed there's not, sir," replied the man.

Cheering ourselves thus we made ready in the fishing lodge and walked across the meadow armed cap-d-pie; flies - a March brown, blue dun, and February red. There are not many streams in the three kingdoms that will repay for whipping in the second month of the year, but the Usk, and other smaller rivers in that part of South Wales, are fairly and legally open to the rod at the beginning of February. Excellent sport is sometimes had on warm days as the month draws on; March and April are indeed accounted the best months in the year. The Mayfly brings no harvest to the Usk as to other trout streams, the stock flies throughout the early months of the summer being the March brown, blue dun, and coch-a-bondhu, with slight variations of shape and size according to the altered conditions of the water.

The Usk at the portion we attempted is sparkling and lively, but plays no unseemly antics, as it flows along its level bed, meandering freely around oft-recurring bends, and seemingly proud that the mountains standing sentinel over it must in honesty place it in a different category from those 
descending brooks that babble their business to the whole country side. The banks are not encumbered with trees; the angler perceives this and keeps in the background, for, as the Poet-Laureate truly warns us :-

"If a man who stands upon the brink But lift a shining hand against the sun, There is not left the twinkle of a fin."

The captain generously gave me the pick of the streams, and if he was generous I was grateful, and not at all disinclined to take him at his word. Soon an amazing thing happened: I hooked a trout, though the thin ice was. crackling under the feet as I stood to play him-hooked, played, and nearly lost him through the well-meant endeavours of a friend who was commissioned to put the net under him. That which ends well, we are assured by ancient proverb, is well, and it may save the reader some anxiety of mind to tell him, by anticipation, that the trout was ultimately safely bagged. The captain stood in the stream and made the welkin ring with laughter at our bungling. My volunteer assistant was, physically, as fine a man as you would wish to see, and handsome in the bargain : at least, so the Welsh damsels told themselves, and-him. But the landing net was not dreamt of in his philosophy, nor had his burly form been framed for bending low over a steep bank. His innocent but determined attempts to smite the fish off the hook as soon as it came within range, his bewilderment when requested in angry tones to sink the net, his beaming pride when by a lucky accident the trout, escaping a vicious prod he had aimed at its head, ran into the net, were very mirth-inspiring to the captain. And after all this fuss, 
command, entreaty, and (I fear me) abuse, the fish might have weighed half a pound.

The second trout was a beauty, of nearly three times this size; with it no trifling could be permitted. Our friend, therefore, repeating his dangerous assaults, was instantly deprived of the landing net, and the angler became his own assistant. If the truth must be wholly told this anecdote is introduced to pave the way for a morsel of advice. Keep your landing net and gaff in your own hands as much as possible-you will be more independent, less likely to lose fish by trusting to inexperienced strangers, and better able to cope with a sharp emergency when it arises, as sooner or later arise it will.

A third trout completed my bag on this early February day on the Usk. My own London-made March browns, upon which I had with reason prided myself, were, as so often happens, useless : it was a large and unpretending fly given me by the keeper which performed the trifling transactions that I had been able to carry through.

When the fish are rising, and one's stay by a good river is reștricted, all the feeding encouraged during the day should be left to the fish and such like small deer. The keen sportsman cannot afford to throw away half-hours upon knife-and-fork. But on a February day, appetite sharpened by the frost, and hopes blighted by two hours without a rise, asceticism does not commend itself to the pilgrim's affections. Man, after all, is a gross animal. It is humiliating to chronicle the admission, but it is true, that the feature of that particular day which stands out most boldly in my recollection is-not the drive along the mountain side, not the yellow furze blossoms and silvered branches, not the 
genial companionship of my gallant young guide, not the rescue of the trout from the evil attacks of Adonis, not the sight of a comely Usk trout safe in the depths of the net, but the homely table in the fishing lodge garnished with a leg of real Welsh five-year-old mutton fed on the home farm and roasted artistically. Man, I repeat, is a gross animal ; but for all that, mutton when it is Welsh, when it is five-yearold, when it is well roasted from knuckle to blade, is not to be put aside in terms of contemptuous indifference.

The afternoon passed principally in an inspection of the pools for salmon, of which we saw several. The keeper had hooked one which he pronounced an "old Turk," and set at liberty, not because of its oriental attributes, but because it was not in season; the captain also had turned one over, and I had scared a small fellow from the water's edge. The Usk is as late a river for salmon as it is early for trout. When was the Usk not famous for its salmon? Poets wrote about it in 1555 :-

"In Oske doth sammon lye, And of good fish, in Oske, you shall not mis; And this seems strange, and doth through Wales appere In some one place are sammons all the yeere.

So fresh, so sweet, so red, so crimp withal, That man might say 'Loe' sammon here at call."

Coming from the sixteenth to the nineteenth century it is not difficult to furnish a convincing proof of the abundance of Usk "sammon." Not many seasons since a gentleman, who himself related to me the circumstance, counted on a bend of the river not more than 200 yards long thirty-nine old or spent fish that had perished while waiting for floods to take them to the sea. Mr. Robert Crawshay, the iron 
king, rents a large section of the Usk, and is one of the most enthusiastic of its anglers. On the 2 nd of October, 1874, he himself-other members of his family also killing fish-caught nine salmon-a male of twenty-two pounds hooked in the pectoral fin, a female of sixteen pounds at the same time and place, also caught by the pectoral fin, a female of nineteen pounds hooked in the side, and the remainder-all hen fish-taken in the ordinary way-thirteen pounds, ten pounds, eight pounds, five and a half pounds, four and a half pounds, and four pounds-total 102 pounds. To the recreation of angling Mr. Crawshay adds that of photography, as frequenters of our art exhibitions will remember, and he makes the one wait upon the other in a manner very interesting to the pisciculturist. The whole of the salmon taken on the day specified he photographed, for scientific purposes. The three largest were photographed separately on an extended scale and partly opened, so as to show the precise condition of the fish in spawn. The roe in the nineteen pounder appears ingeniously exposed in its natural position; it weighed three pounds ten ounces, and as the number of ova in one ounce is 380 , the eggs in this one salmon numbered 22,040.

Frost in February is not out of the course of nature, but what say you to a Whit-Monday hailstorm? Was that the reception the mountains of North Wales should have given to a confiding man who had travelled two hundred and thirty miles to pay them (and their water-basins) due homage? Yet even so it happened. On the Saturday previous I had diligently fished up the meadows of Nant Ffrancon, or the Beaver's Hollow, content with a satisfactory basket of small trout, revelling in the wild loneliness of the 
valley, and almost happy; the drawback was a herd of Welsh cattle which, led on by a scoundrelly little bull, chased me with most malicious intent, and interfered sadly with the peace of mind which would otherwise have invested me like a mantle. For skirmishes of this nature the angler in North Wales must be prepared; they are much too generally part of the sport.

Llyn Ogwen as the bonne bouche had been reserved for a long day. They never fish on Sundays in Wales, but the quarrymen take long walks into the country, and come home in the evening with something moist in their handkerchiefs. On Whit-Sunday, walking up to reconnoitre, and order a boat, I myself saw a few movements by Ap-Evans, Ap-Jones, ApWilliams, and Co., which fully explained the odour of fried fish that pervaded Bethesda at night. A lovelier day than this never dawned ; the wild hyacinths, primroses, buttercups and daisies, bloomed fresh and fair in the private grounds through which you are permitted to cut off a long turn in the high road; the birds sang out of the fullness of their holiday heart; the fleecy clouds ran lightly before the wind over the hills; the air, soft and amorous, cooled you with a fan of balmy perfume.

The craggy mountains and stupendous rocks at the upper end of this valley seem made for storm and gloom only, but they did not take this clear June sunlight amiss, and made no opposition to its beams searching out and revealing weird clefts and chasms said in legend to be the abode of devils and imps; one precipice by Llyn Idwall was and is believed by the superstitious to be the main entrance to Satan's kitchen, and is named Twll-ddu accordingly. The fish in Lake Idwall, says Welsh tradition, were, in memory of 
the murder of a prince by his ruthless guardian, for ever doomed to the loss of one eye; the guide books tell you that, as there are no fish left in the lake, it is impossible to verify the legend. Unfortunately for the unity of this touching narrative-one does not like to have one's idols shattered-Lake Idwall on this Whit-Sunday was considerably dimpled by the rising of fleshly trout, and one fish leaping a somersault out of the water to all appearances was not the victim of optical defect. Still it is a horribly gloomy pool, dark and remote amongst the mountains, and frowned. upon by savage rocks.

Lake Ogwen is more open, and more easily accessible, and there is one house tolerably near. You fish the lake from a boat, and in the absence of an oarsman-and there is no such thing in the locality-you heave a block of granite attached to a rope over the windward gunwale, and let the shallop drift.

On the Whit-Monday morning with which we are now concerned the mountains were hooded as if with gigantic masses of cotton-wool, curling slowly into fantastic figures, dispersing and gathering, stealing down towards the valley, trailing over the faces of the rocks, and performing a thousand weird movements. The wind began to blow from the gorges, cutting you like a knife. Having pulled the clumsy dingy half a mile in the eye of the wind, I was not slightly provoked to find the quickening blasts converting me, as I stood waiting for a lull, into a sail, and the boat, notwithstanding the granite drag, hastening back at a prodigious rate, and threatening shipwreck upon a cluster of serrated crags at the lower end. The affair ended in an hour's furious gale, to which the hapless angler was exposed, 
there being no possibility of pulling ashore, and no cover under the mountain, at whose lee-foot the boat lay partly beached. Then the gale, quickly running down the chromatic scale of Boreas, whispered itself seaward. The sun at last came out, not with the open and frank countenance of a friend, but with the pallid cheeks of a conspirator.

Now, or never, was the time to put off once more, and soon the flies, five in number (as you may make them on this weedless water), were tripping lightly to and fro. Thirty minutes of sun, even if feeble, and sport, even if in moderation, are helps to endurance, and sets-off against a drenched skin. In that space I had caught fifteen trout of a peculiar kindvery yellow, very thin for their length, very greedy after the fly, very stupid when hooked, very slippery when handled. If I add that the fish weighed three pounds gross weight, there will be no injustice done as between man and trout.

The last fish was being played when, as an effective finale, a hailstorm burst. I had been too intent upon fishing to notice it brewing overhead, but it speedily gave me a taste of its quality. Of course the boat was the farthest possible point from land; of course I was the longest possible time in hauling in the granitic contrivance; of course the wind mastered the oars; of course everything went wrong. The discharge of the Storm-King's extra-sized small shot caused acute pain to face, hands, and neck, and drove me huddled and heedless into the bottom of the boat, which went whithersoever it listed, and this, to sum up the catalogue of woes, was on the rockiest part of the foreshore. Ten minutes' peppering with large hailstones seemed a whole day of pain and discomfort, and there was an accompaniment of thunder and lightning that added an element of awe to the warfare. 
This was a holiday not to be forgotten : I did shorten it as soon as the storm abated, and sought shelter in the cottage.

Through its green glass window panes, long after comparative serenity had succeeded to our elevation, we could see the pale blue forks cleaving the clouds far down the valley, and every token of a repetition of the commotion which had visited us. The masses of cotton-wool, no longer white, brooded henceforth slate coloured and sullenly over all the hills, and bird and beast had vanished from sight and sound when the homeward walk was, in dampness and shivering, prosecuted.

The main result of my visit to Llangorst Pool was to induce a deep-rooted scepticism on the subject of waterproof clothing, and sincere pity for two unoffending friends whom I had tempted from the hotel fireside with exciting promises of sport, and positive assurances that the weather would be fine, and the scenery observable under the most favourable auspices. This, to be sure, was a daring thing to do in February, but the weather-glass in the hall, and the weather-glass aloft, to say nothing of the head boots, backed me in my honestly-meant persuasions. And we departed at noon, and took train to Tallybont station.

Merthyr Tydvil is a metropolis truly, but it is the metropolis of coal and iron. Even when the grimy workers are contentedly toiling, the town is the reverse of cheerful of aspect; when they are on strike, when the great blast furnaces are blown out, and trade is stagnant, it cannot be said that additional liveliness has been secured. But down the valley through which the Brecon railway has been laid you very quickly reach fine scenery, which you appreciate all the more, perhaps, because of distant views of chimneys 
belching forth serpent coils of dense smoke. This I pointed out to my trusty and, alas! trusting companions, with the laudable desire to divert their attention from numerous ugly appearances overhead. For the turn of noon was stealthily lowering a curtain, first of gauze, then of more thickly spun veilwork, till hill and vale, streamlet and lake, were alike hidden from view.

A little local knowledge, or any improvised plausibleness that will pass as such, is a boon under such circumstances, though one is apt to find out that a little knowledge is, as forsooth it has been from the time of Adam, a dangerous thing. All I know of Llangorst Pool I nevertheless place at the disposal of my companions, but my data, even when drawn out like thin wire, do not go far. The Welsh name of this water is Llyn Savaddon; it is three miles long, and a mile across at the widest place. Although there are numerous legends connected with it, the only one I can recall, now that of all times they are needed, is that the waters rest upon a deeply-buried city. One of my companions has heard the same story of an Irish lake, and makes game of the whole pretence.

He gets more interested at the stores of eels, perch, and pike, which I vouch have roamed the pool since the days of the good monks of Llanthony, and becomes almost hopeful when informed that the place is credited with pike of any size up to 5 olb. He remembers, he says, a paragraph not a fortnight since in a London paper recording the capture of one of $24 \mathrm{lb}$. from Llangorst; hopes I have been careful to bring the gaff; thinks if my bag is too small we may borrow or purchase a market basket or potato-sack.

Dissembling, however, could be continued no longer. It 
began to rain hard and straight, and I was weatherwise enough to be sure that it would rain for the rest of the day. Better have told those young men to wait in the warmth of the station refreshment room till I came back; better even have myself taken the next returning train. But hope springs eternal in the human breast.

"Fifty pounds, I think you said ?" observed the friend who knew all about the Irish lakes, as he resolutely tucked up his trousers.

It was this phantom that inspired him to follow us through those sodden meadows and slippery marshes into the rainbeaten village nearest the pool. The other friend bore up manfully till he reached the tavern settle, and then he brought up to his moorings under a wharfage of smoked bacon, wishing us luck, and requesting to be awakened, if he slept, when we returned with the game.

"Fifty pounds is a fine fish, old fellow," the more hopeful companion said as we trudged through mire and rain. $\mathrm{He}$ could think of nothing but that. Sympathy I could tender him none, having just discovered that a new waterproof suit warranted to stand fast, let in water like a sieve, and being mentally engaged in debating whether there is anything in the world so thoroughly illustrative of "adding insult to injury" as a waterproof garment that assists the rainfall to saturate you.

A brave little Welsh boy, as we stand lingering shivering on the brink, offers to pull us out into Llangorst Pool. His offer is accepted, and I work like a galley slave with the rod and spinning tackle. There are two other water parties, but they are coming in, and without waiting to be asked they tender the tidings "Not a touch to-day." The assurance from one 
gentleman who had given over fishing and was dangling his spoon over the stern, to the effect that the pool was full of pike, and that he had caught ten prime fish yesterday, was not received with that genial delight one sportsman should feel in the prosperity of another. My friend, couched under the umbrella in the bows, surveyed me with grim speechlessness, and smiled. Thank goodness, he referred no more to the abnormally high maximum I had given him to represent the weight of the Llangorst monsters. Yet I had read the same in honest printer's type.

The afternoon, in short, was the deadest of blanks; it rained incessantly. The road by which, at the expense of an additional half mile, we avoided the terrors of mead and bog on our return, was more unpleasant than our former route; the trains were late; the whole prospect blurred and blotted. I have a vivid remembrance of that unlucky Saturday; for I ruined a new hat, caught a severe catarrh, found out that the waterproof man had cheated me, and have reason to believe-no friendly communication having been received from him since-that I mortally offended an intelligent and useful acquaintance because of that fiftypound pike.

\section{Practical Notes on Welsh Waters.}

Having determined to write the history in brief of three unlucky days in Wales, and having fulfilled my purpose, I must, in justice to Wales, hasten to show that there is a reverse side to the picture of its angling capabilities. Days, happily the opposite of those I have described, have I enjoyed as regards both weather and sport. Wales can still 
give you, as in the olden days, prime trout and salmon angling, but it is always wiser to push farther than the beaten track of tourists. The strongest claim the country has upon English anglers is its nearness to them. Leaving Euston at night, you may be casting a fly upon mountain lakes by breakfast time next morning. Salmon used to be to Welshmen what bales of cloth are to the Central Africans -specie payment. Hence the lines :-

"Though weak and fragile, now I'm found With foaming ocean's waves around, In retribution's hour I'll be Three hundred salmon's worth to thee."

Let the angler get up into the mountains, and be prepared to rough it, securing a lift by coach or cart as opportunity offers. The loneliness of the land will be compensated for by the finny company in the streams. Carnarvonshire is a rare country for artists and fishermen; and Merionethshire and Denbighshire abutting upon it are scarcely inferior. Dolgelly, Bangor, Aberystwith, Barmouth, and Betts-y-Coed are serviceable head-quarters. In South Wales, especially in Glamorganshire, the collieries and mineral workings have ruined many a fishing stream, but outside of the mineral basin, and even on the hills within it, trout may yet be found, and are frequently potted by prowling pitmen filching them from under the stones, when other means of obtaining them fail. In Carmarthenshire there are the Towy and Tave; Radnorshire receives the Wye eighteen miles out from Plinlimmon, and there are many small streams and lakes in the county; Brecknockshire is rich with Wye and Usk. 


\section{CHAPTER XII.}

\section{OUR CLOSING DAY.}

"Should auld acquaintance be forgot, And never brought to min'? Should auld acquaintance be forgot, And days o' lang syne? We'll tak a cup o' kindness yet For auld lang syne!"

Nor to the waterside at all must the reader-kind, intelligent, and indulgent, of course-be now transferred, but to a warm, well-lighted apartment to which he has been aforetime introduced. On the last night of March, it may be remembered, a united family, not ashamed to avow themselves followers of quaint, pure-hearted Izaak Walton, whose nature was eminently unselfish, assembled amidst their piscatorial trophies on the eve of their "opening day."

Since that occasion three of the four seasons have sped their allotted course. It was an occasion for the putting on of harness, just as the present is the time when the waterside warriors have met to lay it aside, 'and, so to speak, place their weapons on the rack. The twenty-eight pound pike, that great perch, the bellows-shaped bream, the dark fat tench, the burly-shouldered chub, and the handsome trout maintain their fixed expression upon the walls. The hand of change touches them not. Two, however, of the angling brotherhood have for ever laid down the rod since 
the year opened, although both were merry and hale on that Ist of April expedition by the waterside. Though their places have been filled, our departed friends are not forgotten ; on the contrary, as we stand in informal groups around the fire, awaiting the expected summons, their good qualities are lauded and their skill is sadly remembered.

In due time the cloth is removed, and preparations are made for "a night of it." We are very old-fashioned and conservative here, as we have been any time these last fifty years. A few of the very young brethren have incurred the pity of the majority by drinking claret during the feast, and they now are given up as hopeless because they produce elegant cigar cases, and talk of Partagas and other fashionable brands. Rare old brown sherry, port with real bees' wing, and ripe, fragrant Madeira have been circulated amongst the veterans, and now nothing but the longest of churchwarden pipes, artfully twisted spills quite a yard long, tobacco on small trays, and an open line of glimmering night lights posted down the centre of the mahogany, with mighty bowls of punch such as this generation seldom sees, will satisfy the traditions of past gatherings, and the tastes of present feasters.

We are very practical. The president raps the table with an ivory mallet and says "Gentlemen, "The Queen." We rise and say "The Queen," sip, and sit again. "Gentlemen, the secretary will make his annual statement," says the president. Thereupon we are informed that the past season, like the season before it, was a miserable time for anglers. Last year there was too much rain; this year there has not been enough. The fly-fishers who had 
travelled far and wide had found the trout streams barren and dry; the bottom-fishers had been scorned by the roach, put to shame by the perch, and left in the lurch by the barbel. The pike-fishers still lived in hope, but until sharp frost cut down the weeds, and floods washed them away, the angler could not be said to have a fair chance.

"Gentlemen, pipes," laconically, and formally rising, now observes the president. This is tantamount to the military "stand easy," and clouds arise and tongues are loosened without a moment's delay. Every member is required to contribute to the entertainment of the general body, beginning with the oldest and proceeding down the incline of seniority. Thus no time is wasted in profuse excuses or affected apologies. You may sing, or perpetrate a speech, or recite, or stand on your head, but you must do something, and bring your contribution within a hard and fast compass of five minutes.

The fence-line of three score years and ten has been passed by our patriarch-the dear old man of whom we are all so proud, who was never known to lose his temper, to do his fellow an evil turn, or to pass the bottle; who this very autumn sent up from the Shropshire streams a fine dish of grayling caught by himself, with flies of his own making. He is a "character," and has an unfaltering belief in the old times.

"I'm an old-fashioned fogey," he tells us, "but I don't think you youngsters are as jolly or genuine as the anglers of my early days. You are over-wise in your own conceits, bless your hearts; but it's only theory. You read more, but you modern anglers are not half as good naturalists as 
your fathers were. You can give the scientific name of a polecat, but you never saw it, and if you met one walking down Regent Street you wouldn't know what it was. Now, when I was a young man I shot a polecat in the very copse some of you know so well at the back of the osier-bed. I doubt whether you know a hawk from a handsaw."

Here our gay comrade, who is nothing if not Shakespearian, interposes "Hernshaw, not handsaw." General laughter succeeds, in which the patriarch joining continues :-

"There you are. It's precisely what I mean-you youngsters know too much. I say handsaw, and stick to it. But there, it isn't your fault altogether ; the world moves on and things change. The time is past when a kingfisher perches in confidence on the rod of an angler, as I have known it to do. But it's all right, and I'm delighted to be here once more. I can't throw a trolling bait any longer, and I've as much as I can do to see a rise a dozen yards oft if there's a ripple, but I enjoy my summer outings and the soft winds as much as any; and if I can't wade in a swift stream or do a day's spinning, I can nick a grayling with the best of you." And indeed he can; and the old man hopes that God will bless us all, and that when we are in our seventy-second year we shall be as hearty and happy as he is. To which we add an internal "Amen" in the midst of the applause.

The next gentleman would make a splendid backwoodsman, if six feet two of straight lissome framework and an unquenchable love of field sports count for anything. Yet he has a gentle soul in that long muscular body, and says the tenderest things in a wonderfully sentimental voice. The voice lifted into song is sweet as the pipe of an 
Arcadian shepherd. Though essentially a town-suckled, town-bred, and town-loving man, he thus warbles:-

"Give me the brook at the foot of the mountains,

Where cool, sparkling waters spring fresh from the hill;

Give eddying scours, cascade-hollowed fountains,

And rills rushing down through the glen to the mill.

There's a maid at the mill; there's a trout in the stream;

For the trout will I whip; of the maid let me dream.

"Ah! tell me no more of glory or duty,

Of vict'ries of peace, or triumphs of war;

My mountain-born fish, my mill-nurtured beauty

Are the only delights that tempt from afar.

Yes; the maid of the mill and the trout of the stream

Where'er I may roam ever rise in my dream.

"The trout it is said loves bright summer weather,

And merrily plays at the opening of day;

So stroll I to where the brooks join together,

And wrong would you be should you tauntingly say

'Tis the maid at the mill, not the trout in the stream,

That hastens my footsteps at dawning's grey gleam.

"My first cast falls on the hurrying water,

An old casement creaks 'neath the time-honoured eaves-

A miss! and thy fault, $O$ miller's fair daughter,

Peeping out from thy bower of dew-covered leaves.

Witching maid of the mill ! Lucky trout of the stream !

The angler fares ill who of maidens will dream.

“Lo! here by this spot, where merry trout gambol,

At noon lies the only protection from heat:

At evening, perforce, I hitherward ramble-

Is not the quick flash of the water-wheel sweet?

Hush! The maid of the mill walks forth by the stream;

Shall I follow? Or still idly angle-and dream? 
- Given is the brook at the foot of the mountains,

Where cool, sparkling waters"spring fresh from the hill;

Given eddies and scours, and cascades and fountains,

For they all rush down through the glen to the millAnd I live at the mill, whipping trout from the stream:

I followed, was hooked, and need nevermore dream."

To the sentimental backwoodsman succeeds one who, instead of a prosy conveyancer, should have been, as nature intended him, something in the comic line of life. He does not sing a comic song now, however, since he knows he will by-and-by be called upon willy nilly to repeat certain old favourites of that ilk. The truth is he has for a week been preparing a string of wretched puns, which he thus runs off the reel, drolly emphasising the words italicised: "Gentlemen, I hope no" one will carp at what I'm about to say, or think my remarks an enc-roach-ment. Is it not a fact in natural history that every fack has his Gill? It is not every acute angle-r who can keep a pike, or say with the judicious Hooker,

\section{" I had a bream, a whacking bream, \\ I dreamt that I had three.'}

Before sitting down I should like to state my in-tench-ion of presenting to you, though not by any means as an eelemosynary affair, a copy of Mrs. Barbel's 'Dace abroad and evenings at home,' bound in gut-ta perch-a; also to observe that the true motto for every angler is I' $m$ a float. The fact is "-

The fact was that the company would have no more rubbish of this sample, though the word-torturer subsequently confided to me that his most effective abominations were unsaid. We, however-the conveyancer's cheap wit must 
be the excuse for the simile-only jumped from the fryingpan into the fire, inasmuch as the next three entertainers were terribly dull dogs. One of them floundered (why did not the conveyancer try to work in the flounder?) through two sentences, and broke hopelessly down ; the other recited a soliloquy on "The chief purpose of man"; the third, who had a voice like a saw-sharpener, dashed into "Where the bee sucks," screeching in the most excruciating fashion the long run on the last word in the Bat's back line.

At this stage of the proceedings there was a universal desire for a melody, in which a chorus-singer might hear of something to his advantage, and the member whose turn came next happened to be just the fellow for the crisis. Swinging his pipe and looking round with a now-then-alltogether air, he roared in stentorian harmony :-

"Now Johnny the angler's a jolly lad-hurrah! hurrah !

He's never disheartened and never sad-hurrah! hurrah!

He's out of the racket of trouble and toil ;

He's king of the water if not of the soil :

And light in his step when Johnny comes marching home."

There were eight verses of this home-spun material, the last stanza containing the inevitable moral, in which the author suggested that there could not be a better all-round bait for the angler than contentment, and laid down the indisputable axiom that "Fair-play is a jewel for fishes or men." Probably this was the most roughly constructed song sung during the evening, but nothing could exceed the gusto with which the "responses" were taken up, or the fine effect produced by the raps dealt out to the table as a suitable accompaniment to "hurrah! hurrah!" Another member chanted in a sort of Gregorian the story of 
poor "Cock Robin," and at the end of every verse the whole company, taking their parts like a well-trained choir, gave a pretty melancholy refrain :-

"All the birds in the air fell a sighing and sobbing

When they heard of the death of poor Cock Robin."

True, sobbing according to usage does not strictly rhyme with Robin, but we were not fastidious, and were not tired, although the verses were just as numerous as the birds, beasts, and fishes who were concerned with the tragic decease and touching interment of the defunct Redbreast. 'The late Mr. Weiss himself could not have sung the "Village Blacksmith" better than it was given, and there was one who came so close to reality in his imitation of the veteran Ransford that it was necessary to look a second time to decide whether it was not that splendid interpreter of Dibdin who sang and acted "Tom Tough." Next to the Cock Robin chant in popularity amongst the chorussingers was a singularly quaint and catching slave song brought by a young member from Carolina, where he had heard it sung by the plantation hands. The general burden of the solo I have forgotten, but the chorus printed itself upon the memory at once, and I fancy it gives a pretty clear notion of the rest :-

"There's a good time coming and it's almost nigh,

It's a long, long time on its way.

Then go and tell Elijah to hurry up Pomp

And meet us at the gum-tree down by the Swamp,

To wake Nicodemus to-day."

There are aggrieved anglers as well as parishioners, and our aggrieved member carried the meeting entirely with 
him on introducing the great live-bait question. This he maintained was the question of the day, and though he hesitated to commit himself to a definite statement, he broadly hinted that Government must sooner or later take it up. Giving head to the righteous indignation which rippled through his voice he graphically depicted the mingled horror, disgust, and disappointment suffered by honest anglers who were unable to secure live-bait for love or money. A pretty state of things, forsooth! Here were hundreds of fine fellows who spend the Sunday meditating calmly by the murmuring river, and innocently angling, who must be robbed of their enjoyment if the fishing tackle shops could not procure live-bait. If there were laws against the capture of small fish let the laws be altered; what was the use of Government if the wants of the people were not supplied? The author of these ideas of political economy worked himself into such a passion that his five minutes had expired before he could arrive at the one or two practical suggestions he intended to make.

The gentleman next in order trolled a song (written by Mr. G. Manville Fenn) which was twice encored, for it was new and bright and capitally rendered :-

\section{THE FISHING PHILOSOPHER.}

"To tramp the wet turnips, and pepper a bird;

Or butcher tame pheasants to me seems absurd:

Give me the soft streamlet, meandering by,

Where I can take trout with a well-chosen fly :

"And my rod light and limber, my line true and fine,

My creel on my back, and a scrap when I'd dine;

Sweet Nature around me; the world's troubles far;

Believe me we fishers philosophers are! 
"With beagle, or greyhound, go hunt puss, the hare,

Or chase, in gay scarlet, the fox to his lair ;

Give me my roach tackle; of ground bait a heap ;

A fig for all else, be the stream swift and deep :

"For my rod light and limber, \&c.

"You may shoot, you may hunt, you may stalk the red deer;

Let me list to the music of some falling weir,

While I tempt the sly chub, the fat barbel, and jack,

Oh! I envy no king if I bear a few back :

"With my rod light and limber, \&c."

That gallant acquaintance, the gay comrade, was observed closely, and his friends knew by the dignified reserve ennobling his brow that that tempered brain had prepared for us an intellectual treat. He had dealt with what may be termed the melodramatic aspect of the recreation to which we were all devoted. He poured out his soul in recitation, thus :-

"I greet thee, friend, upon this autumn day, And give thee welcome to this sheltered lake.

Here for a season let us haply stay,

Of this good weed-Returns-I pr'ythee take.

So gaze we now upon the tinted leaves

Which mix their colours by their own good law. Breathes there the man who in his heart believes That Providence is not above us? Psha! Fill up thy pipe, thou tall, thou goodly youth, And strike a light upon this roughened edge. See'st thou the float?

"Alack in naked truth

It still bobs pikeless near yon fringe of sedge.

Now let us therefore our discourse resume.

Another light? With pleasure ; strike it low ;

(The worst of fusees is their-well-perfume.)

Those drifting clouds are white as driven snow.

What is the theory of wind, of heat, of cold ?

Why points the needle to the northern pole? 
To deal with these a man must needs be bold.

Pray sink the bait can in that nearest hole, Else will those gudgeon prematurely die,

Nor roach nor dace their little span will save.

I'll give my bait, I think, another shy;

E'er saw'st thou pike so cowardly behave?

Mark now these th irty yards; how neat they show,

Coiled carefully upon the level ground-

One, two, three-swish-call'st thou not that a throw ?

That should a good fish take, if one's around.

Have you the papers seen? or Punch? or Fun?

It doesn't matter; only one gets dull

On hours of waiting.

"Look! by Jove, a run.

Down goes the float. See how the pike can pull.

This is as it should be. I dare would bet

A heavy jack is running out the line

Into deep water, into deeper yet

Before he gives a pause.

"Let us combine.

To drink his health. Unscrew thy silver flask

And sip we lightly the ambrosial tap;

Now turn with caution to the genial task.

In grass or sedge should we our capture wrap?

Prepare the gaff with care, else do I vouch

Our prize may vanish at the nick of time.

A little moment further shall he pouch ;

To strike in haste is piscatorial crime.

Haul in the line with very cautious hand:

Thus the requirements of the case are met.

I'll show you how a captured pike should land

And you, the lesson learned, will not forget.

I gently strike soon as the line is taut-

Though the barbed hook has doubtless done its work ;-

The bending rod denotes a finster caught,

The plunging top betrays his angry jerk.

He's spent, I ween, as warily he's drawn,

Reluctant, but not hostile, to the shore.

The winch revolves.

"Here on this grass-grown lawn

Shall lie the prey, to murder fry no more.

The float appears from the pellucid deep, 
Then comes the knot that fastens line to trace;

A moment yet and you may snatch a peep

Of the hooked Luce, now winching in apace.

About five pounds would be a shrewdish guess,

If one may judge from shoulder, fin, and tail,

Which he betrays-maybe a little less.

Ah ! hapless fish, useless it is to sail

To right, to left, with that indignant stroke.

This trusty gaff was never known to fail.

You'll shortly find it is no passing joke,

Though 'gainst your plight 'tis not for me to rail.

So so : your yellow side is upward turned;

As good you are as numbered with the slain,

And you, good friend, the lesson well have learned-

Begad, he's off! the gimp has snapped in twain."

By the time that the Waltonian brotherhood rose, crussed hands, and pronounced that fine benediction, "Auld Lang Syne," they had thoroughly gorged-not the meat and drink, to which they had, nevertheless, sensibly done justice, but-that bait, Contentment, which had been recommended to them by the Boanergesian soloist. So at peace with the world were they that even the Home Secretary, at whose new mandate the party was prematurely dissolved, was pardoned as a victim rather than condemned as a persecutor. With all their hearts they wished each other health and happiness, abundant sport by the waterside, prosperity at home, and no missing faces at the next merry meeting. 








\section{BOWNESS \& BOWNESS}

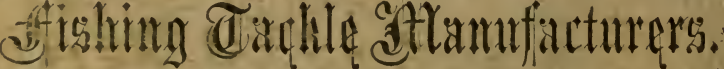

BOWNESS'S SALMON RODS, GREENHEART, from $30 \%$

BOWNESS'S MAHSEER RODS and TACKLE of every descripiion.

See Thomas's Book, "Rod in India.".

BOWNESS'S SPLIT CANE SALMON TROUT ROLS, with supcrior elongating Butts.

BOWNESS'S THAMES SPIVNING RODS, Imprued linches; Patent I ines, Baits, and Tarile of ever wesiription.

Guiliti r.Y RODS, two tops best.

TROUT and GRAYLING FLIES, $2 /-$ per doz.

SALMON and LOCH FLIES in great variety.

WHALEBONELANDINGRINGS and Improved Nets that do not catch the hooks.

TACKLE CASES fitted for all parts of the world.

Bowness \& BOWNess, 230, STRAND, near Temple Bar, LONDON.

Catalogues gratis. The New Francis Francis Fly Book and Flies. 